\title{
The cavernicolous Oniscidea (Crustacea: Isopoda) of Portugal
}

\author{
Ana Sofia P.S. REBOLEIRA ${ }^{1, *}$, Fernando GONÇALVES ${ }^{2}$, \\ Pedro OROMÍ ${ }^{3} \&$ Stefano TAITI ${ }^{4}$ \\ 1,2 Departamento de Biologia \& CESAM, Universidade de Aveiro, \\ Campus Universitário de Santiago, 3810-193 Aveiro, Portugal. \\ ${ }^{1,3}$ Departamento de Biología Animal, Facultad de Biología, Universidad de La Laguna, \\ 38206 La Laguna, Tenerife, Islas Canarias, Spain. \\ ${ }^{1}$ Zoological Museum, Natural History Museum of Denmark, University of Copenhagen, \\ Universitetsparken 15, 2100 Copenhagen Ø, Denmark. \\ ${ }^{4}$ Istituto per lo Studio degli Ecosistemi, Consiglio Nazionale delle Ricerche, \\ Via Madonna del Piano 10, 50019 Sesto Fiorentino (Firenze), Italy. \\ *Corresponding author: sreboleira@ua.pt \\ ${ }^{2}$ Email: fimg@ua.pt \\ ${ }^{3}$ Email: poromi@ull.es \\ ${ }^{4}$ Email: stefano.taiti@ise.cnr.it \\ ${ }^{1}$ urn:1sid:zoobank.org:author:338DE845-4839-4EF5-B684-587C021F076C \\ ${ }^{2}$ urn:lsid:zoobank.org:author:4B8A2E04-3543-465F-9949-B7E1745DA931 \\ ${ }^{3}$ urn:lsid:zoobank.org:author:00F2ACC4-308B-4BEE-BBA4-DE6AC8905449 \\ ${ }^{4}$ urn:Isid:zoobank.org:author:62E97059-6AE5-4984-9ABB-7FB6F7358BD6
}

\begin{abstract}
The study of subterranean Oniscidea in Portugal has been neglected for nearly 70 years, but recent investigations have revealed high diversity. All the terrestrial isopods known from caves of mainland Portugal, including data from the literature and new material, are listed, revealing new biodiversity patterns. Twenty-seven species, belonging to 15 genera and six families, are known, of which 16 species are considered to be exclusively from subterranean ecosystems, i.e., troglobionts. Trichoniscidae is the most diverse family. Seven species in the family Trichoniscidae and one species in the family Styloniscidae are described as new (all with Reboleira \& Taiti as authors): Trichoniscoides bellesi sp. nov. from the Montejunto Massif; T. sicoensis sp. nov. from the Sicó Massif; Metatrichoniscoides salirensis sp. nov. from the typhonic valley of Caldas da Rainha; Troglonethes olissipoensis sp. nov. from the Lisbon Peninsula; T. arrabidaensis sp. nov. from the Arrábida Massif; Miktoniscus longispina sp. nov. from the Sicó Massif and Cesaredas Plateau; Moserius inexpectatus sp. nov. from the Estremenho Massif; and Cordioniscus lusitanicus sp. nov. from Alentejo and Algarve, the southernmost provinces of Portugal. The subgenus Trogleluma Vandel, 1946 (Armadillidiidae) is raised to genus level. In this geographic region terrestrial isopods are the richest group of cave-adapted animals.
\end{abstract}

Key words. Isopoda, new species, troglobiont, subterranean ecosystems, Iberian Peninsula.

Reboleira A.S.P.S., Gonçalves F., Oromí P. \& Taiti S. 2015. The cavernicolous Oniscidea (Crustacea: Isopoda) of Portugal. European Journal of Taxonomy 161: 1-61. http://dx.doi.org/10.58552/ejt. 2015.161 


\section{Table of contents}

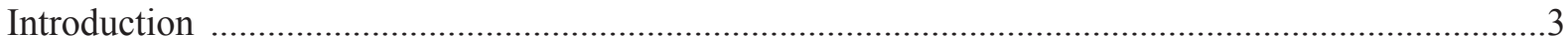

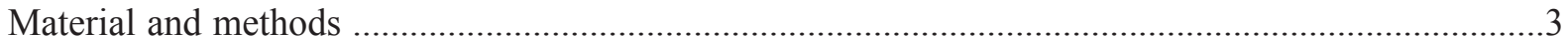

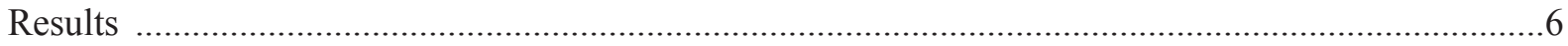

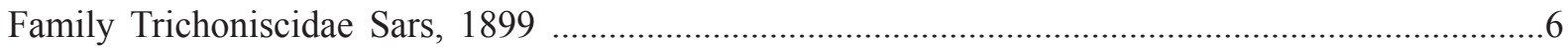

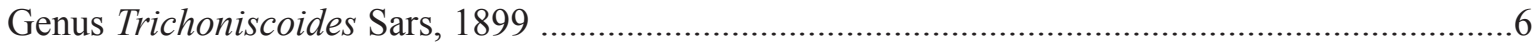

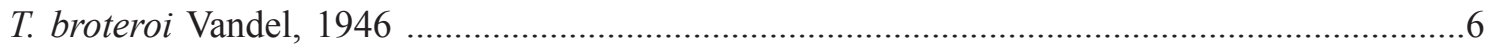

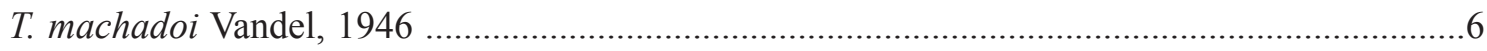

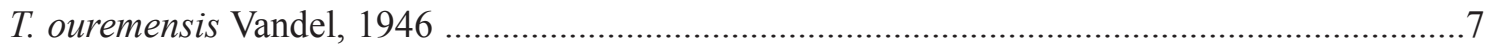

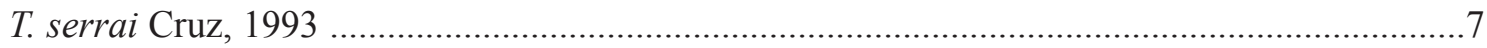

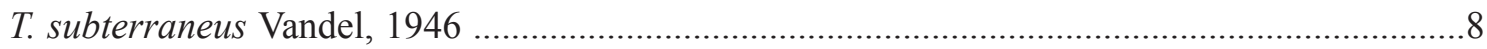

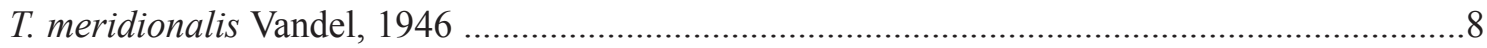

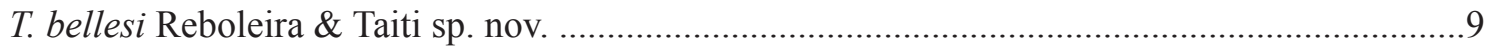

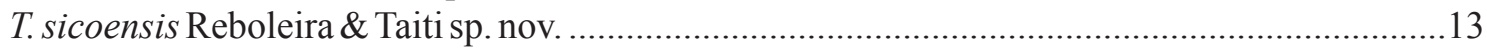

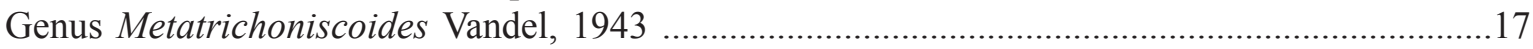

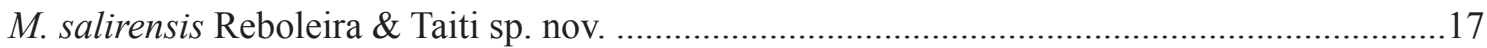

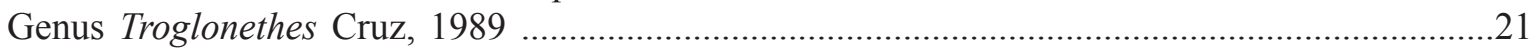

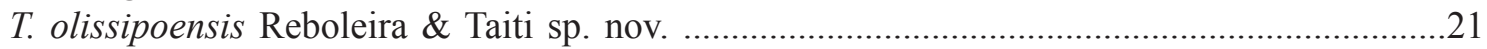

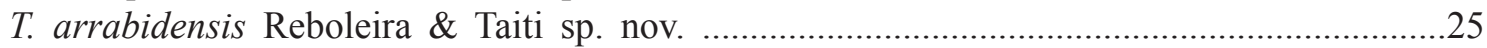

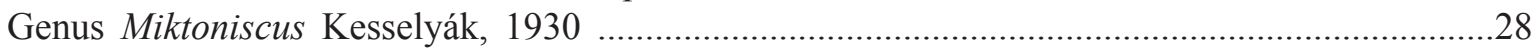

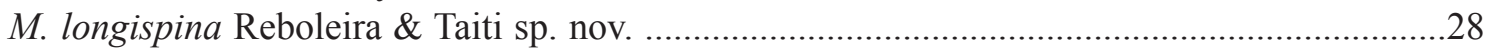

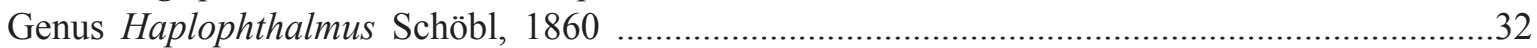

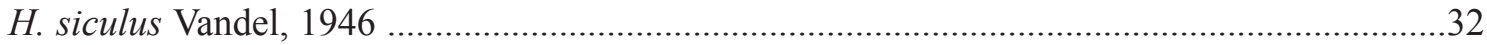

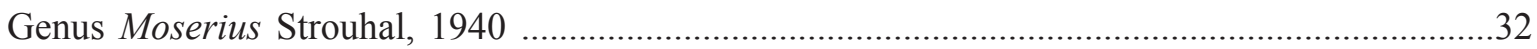

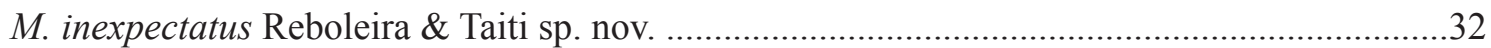

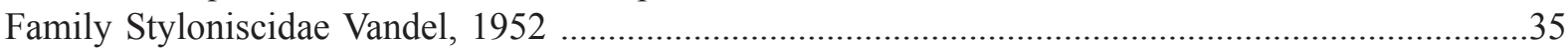

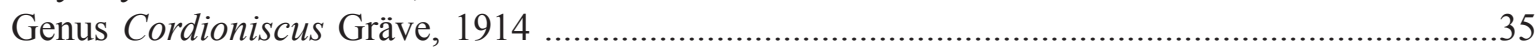

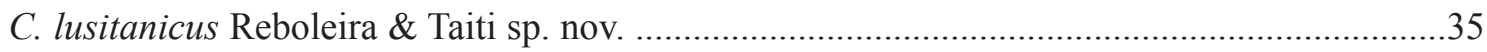

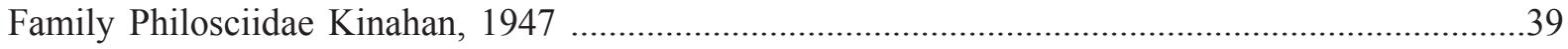

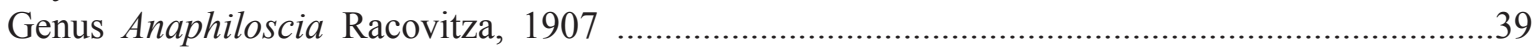

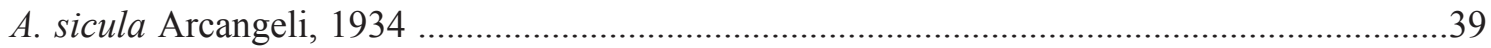

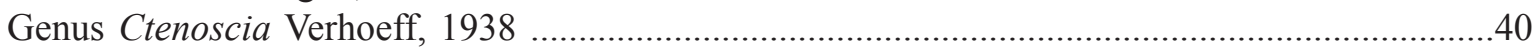

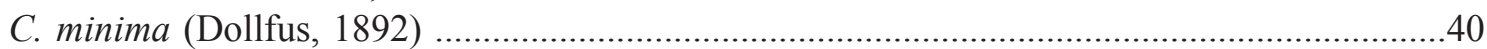

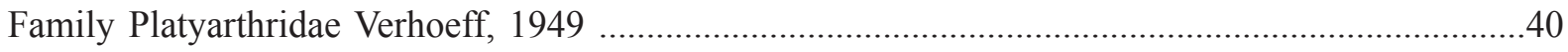

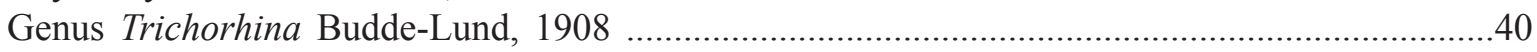

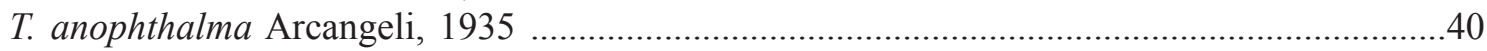

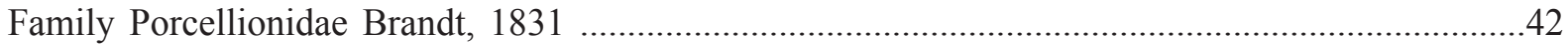

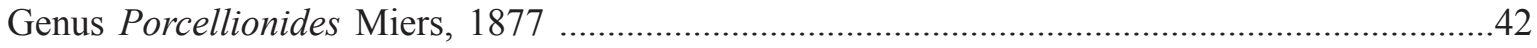

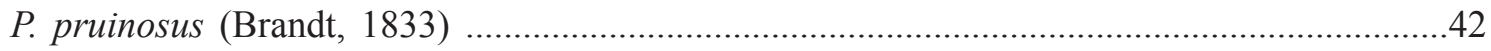

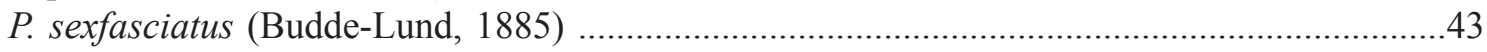

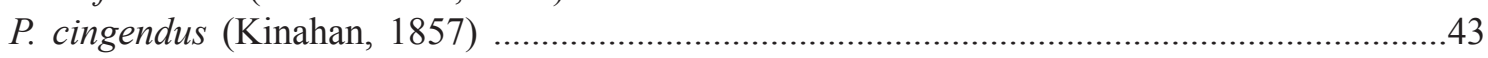

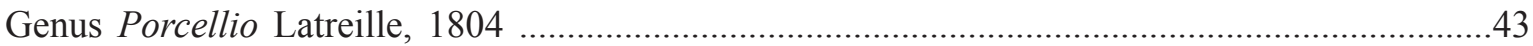

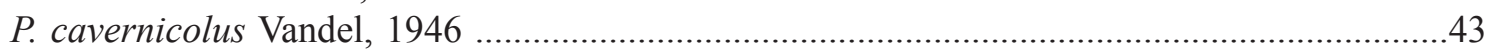

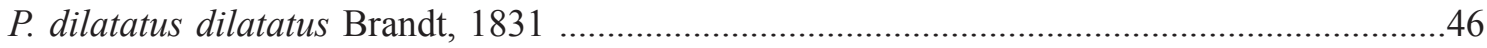

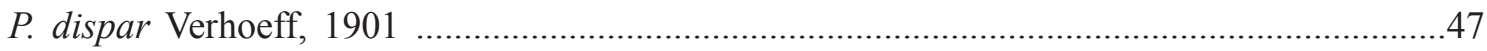

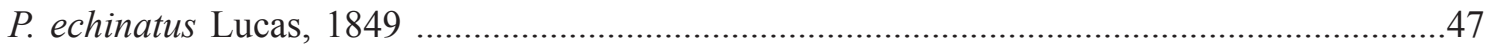

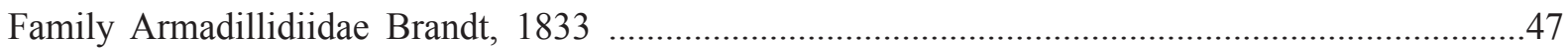

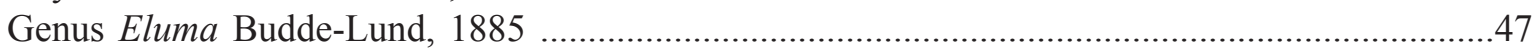

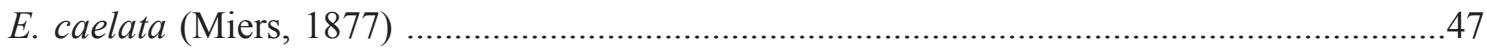

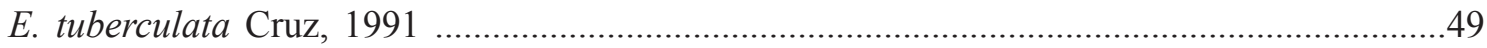




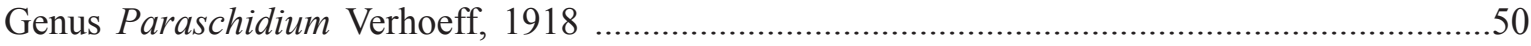

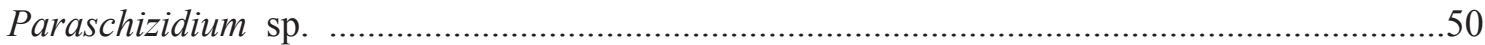

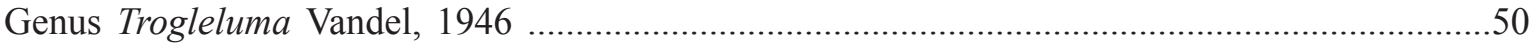

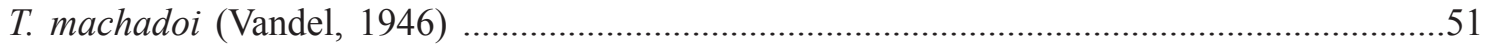

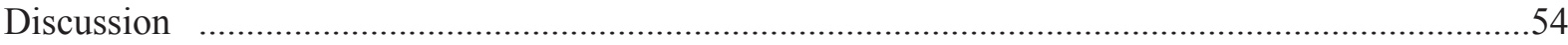

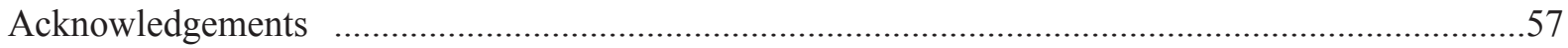

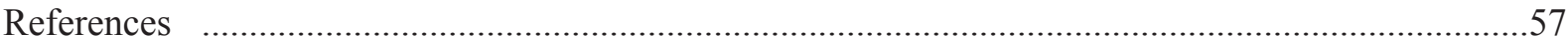

\section{Introduction}

Terrestrial isopods (suborder Oniscidea) play a very important role in the decomposition of organic matter in land ecosystems (Hornung 2011). In subterranean ecosystems they occupy a key-ecological position, recycling organic detritus and being frequent prey of cave predators (Řezáč et al. 2008). Terrestrial isopods are successful land colonizers, but a great majority of species have a high dependence on hygrophilous habitats (Hornung 2011). In fact, they are quite abundant in subterranean ecosystems. Several species of oniscideans have adapted to the aphotic environment, where they can be found in the terrestrial and in the aquatic compartment, including species with amphibian behaviour (Taiti \& Xue 2012; Broly et al. 2013; Campos-Filho et al. 2014).

Oniscidea represent the most diverse group among the Portuguese cave-obligate fauna (Reboleira et al. 2011a, 2013b). Taxonomic studies on the Oniscidea from mainland Portugal are scarce and included mainly in two publications recording epigean and subterranean species by Arcangeli (1935a) and Vandel (1946), based on material collected by A. Barros Machado (for a complete list of Portuguese terrestrial isopods see Schmalfuss 2003).

Prior to this study, only seven species of Oniscidea had been recorded as cave-adapted from karst massifs in mainland Portugal (Reboleira et al. 2011a, 2013b). Five species in the family Trichoniscidae were known: one from the north of the country (Trichoniscoides serrai Cruz, 1993) and four from central Portugal, i.e., Trichoniscoides broteroi Vandel, 1946 from the Sicó karst massif, and T. subterraneus Vandel, 1946, T. meridionalis Vandel, 1946 and T. ouremensis Vandel, 1946 from the Estremenho karst massif. The family Porcellionidae was represented by the species Porcellio cavernicolus Vandel, 1946, known from Sicó, and the family Armadillidiidae by Troglarmadillium (Trogleluma) machadoi Vandel, 1946, found in caves of the Algarve in the south of the country (Vandel 1946; Cruz 1993).

Recent investigations in caves of karst areas from Portugal revealed the presence of several new species of terrestrial isopods. The oniscidean fauna from the subterranean environment of mainland Portugal is here discussed based on literature data and the new material examined.

\section{Material and methods}

Field work was performed between 2007 and 2014 in many karst caves from mainland Portugal and terrestrial isopods have been collected in 29 of these caves (Table 1, Fig. 1). The original Portuguese names for caves are maintained throughout the text, i.e., "Gruta" for a horizontal cave, "Algar" for a vertical cave and "Lapa" for a small cave.

Each cave was monitored in two different zones: just beyond the twilight zone and in its deeper parts. Specimens were collected using baited pitfall traps and active search in each cave, and most were preserved in $70 \%$ ethanol, while some specimens were preserved in $100 \%$ ethanol for future molecular analyses. Temperature was measured with an Aspiration Psychrometer 761 (Lambrecht, Göttingen).

Identifications are based on morphological characters and the pertinent literature. The terminology used in species descriptions is mainly based on Vandel (1960a, 1962). Specimens were studied under Wild 
Table 1. Studied caves in Portugal. Coordinates: UTM WGS; E = entrance altitude in metres; $\mathrm{T}=$ mean temperature at soil level in ${ }^{\circ} \mathrm{C}$.

\begin{tabular}{|c|c|c|c|c|}
\hline Cave & Karst area & Coordinates & $\mathbf{E}$ & $\mathbf{T}$ \\
\hline Gruta de Santo Adrião & Vimioso & $41^{\circ} 32^{\prime} 53.9^{\prime \prime} \mathrm{N}, 6^{\circ} 26^{\prime} 40.1^{\prime \prime} \mathrm{W}$ & 580 & 12.0 \\
\hline Gruta d'el Rey & Cantanhede & $40^{\circ} 17^{\prime} 38.8^{\prime \prime} \mathrm{N}, 8^{\circ} 32^{\prime} 49.3^{\prime \prime} \mathrm{W}$ & 70 & 13.2 \\
\hline Gruta da Arrifana & Sicó & $40^{\circ} 05^{\prime} 22.53^{\prime \prime} \mathrm{N}, 8^{\circ} 30^{\prime} 55.76^{\prime \prime} \mathrm{W}$ & 300 & 16.7 \\
\hline Gruta do Algarinho & Sicó & $39^{\circ} 53^{\prime} 04.5^{\prime \prime} \mathrm{N}, 8^{\circ} 23^{\prime} 05.0^{\prime \prime} \mathrm{W}$ & 208 & 14.9 \\
\hline Gruta do Soprador do Carvalho & Sicó & $39^{\circ} 59^{\prime} 10.1 " \mathrm{~N}, 8^{\circ} 22^{\prime} 57.7^{\prime \prime} \mathrm{W}$ & 20 & 15.1 \\
\hline Gruta da Senhora da Estrela & Sicó & $39^{\circ} 55^{\prime} 41.2^{\prime \prime} \mathrm{N}, 8^{\circ} 32^{\prime} 59.5^{\prime \prime} \mathrm{W}$ & 380 & 13.8 \\
\hline Gruta da Cerâmica & Sicó & $39^{\circ} 55^{\prime} 36.6^{\prime \prime} \mathrm{N}, 8^{\circ} 31^{\prime} 03.6^{\prime \prime} \mathrm{W}$ & 355 & 15.0 \\
\hline Algar da Ervilha & Sicó & $39^{\circ} 56^{\prime} 23.54^{\prime \prime} \mathrm{N}, 8^{\circ} 32^{\prime} 24.39^{\prime \prime} \mathrm{W}$ & 335 & 15.1 \\
\hline Gruta de São Simão & Sicó & $39^{\circ} 57^{\prime} 47.31^{\prime \prime} \mathrm{N}, 8^{\circ} 28^{\prime} 13.62^{\prime \prime} \mathrm{W}$ & 335 & 14.6 \\
\hline Gruta Abrigo Tomar I & Estremenho & $39^{\circ} 39^{\prime} 34.7^{\prime \prime} \mathrm{N}, 8^{\circ} 25^{\prime} 03.6^{\prime \prime} \mathrm{W}$ & 92 & 14.6 \\
\hline Gruta do Papagaio & Estremenho & $39^{\circ} 36^{\prime} 12.17^{\prime \prime} \mathrm{N}, 8^{\circ} 41^{\prime} 11.26^{\prime \prime} \mathrm{W}$ & 419 & 15.6 \\
\hline Gruta do Burro & Estremenho & $39^{\circ} 36^{\prime} 48.43^{\prime \prime} \mathrm{N}, 8^{\circ} 41^{\prime} 21.10^{\prime \prime} \mathrm{W}$ & 390 & 15.4 \\
\hline Algar do Ladoeiro & Estremenho & $39^{\circ} 31^{\prime} 33.01^{\prime \prime} \mathrm{N}, 8^{\circ} 45^{\prime} 15.58^{\prime \prime} \mathrm{W}$ & 485 & 15.5 \\
\hline Gruta dos Moinhos Velhos & Estremenho & $39^{\circ} 32^{\prime} 25.5^{\prime \prime} \mathrm{N}, 8^{\circ} 42^{\prime} 15.5^{\prime \prime} \mathrm{W}$ & 307 & 18.0 \\
\hline Gruta do Almonda & Estremenho & $39^{\circ} 30^{\prime} 17.10^{\prime \prime} \mathrm{N}, 8^{\circ} 36^{\prime} 54.40^{\prime \prime} \mathrm{W}$ & 95 & 18.0 \\
\hline Algar do Zé de Braga & Estremenho & $39^{\circ} 29^{\prime} 16.02^{\prime \prime} \mathrm{N}, 8^{\circ} 42^{\prime} 56.21^{\prime \prime} \mathrm{W}$ & 255 & 17.0 \\
\hline Algar do Vale da Pena & Estremenho & $39^{\circ} 26^{\prime} 48.0^{\prime \prime} \mathrm{N}, 8^{\circ} 55^{\prime} 56.8^{\prime \prime} \mathrm{W}$ & 294 & 14.3 \\
\hline Gruta de Salir & Caldas da Rainha & $39^{\circ} 29^{\prime} 11.64 " \mathrm{~N}, 9^{\circ} 09^{\prime} 56.39^{\prime \prime} \mathrm{W}$ & 60 & 17.3 \\
\hline Gruta dos Bolhos & Cesaredas & $39^{\circ} 18^{\prime} 52.25^{\prime \prime} \mathrm{N}, 9^{\circ} 16^{\prime} 61.37^{\prime \prime} \mathrm{W}$ & 145 & 16.3 \\
\hline Algar do Javali & Montejunto & $39^{\circ} 11^{\prime} 96.5^{\prime \prime} \mathrm{N}, 9^{\circ} 01^{\prime} 71.8^{\prime \prime} \mathrm{W}$ & 380 & 14.4 \\
\hline Gruta da Assafora & Lisbon Peninsula & $38^{\circ} 54^{\prime} 24.80^{\prime \prime} \mathrm{N}, 9^{\circ} 25^{\prime} 17.31^{\prime \prime} \mathrm{W}$ & 89 & 16.7 \\
\hline Gruta da Alvide & Lisbon Peninsula & $38^{\circ} 42^{\prime} 35.7^{\prime \prime} \mathrm{N}, 9^{\circ} 25^{\prime} 32.8^{\prime \prime} \mathrm{W}$ & 42 & 18.3 \\
\hline Gruta do Frade & Arrábida & $38^{\circ} 25^{\prime} 46.56^{\prime \prime} \mathrm{N}, 9^{\circ} 08^{\prime} 10.22^{\prime \prime} \mathrm{W}$ & 0 & 21.5 \\
\hline Lapa da Furada & Arrábida & $38^{\circ} 25^{\prime} 45.8^{\prime \prime} \mathrm{N}, 9^{\circ} 10^{\prime} 28.3^{\prime \prime} \mathrm{W}$ & 159 & 18.1 \\
\hline Algar de Santo António & Alandroal & $34^{\circ} 42^{\prime} 14.2^{\prime \prime} \mathrm{N}, 7^{\circ} 23^{\prime} 59.3^{\prime \prime} \mathrm{W}$ & 370 & 17.6 \\
\hline Gruta de Ibne Ammar & Algarve & $37^{\circ} 09^{\prime} 24.9^{\prime \prime} \mathrm{N}, 8^{\circ} 29^{\prime} 59.4^{\prime \prime} \mathrm{W}$ & 10 & 18.9 \\
\hline Algarão do Remexido & Algarve & $37^{\circ} 14^{\prime} 29.5^{\prime \prime} \mathrm{N}, 8^{\circ} 16^{\prime} 35.6^{\prime \prime} \mathrm{W}$ & 131 & 18.1 \\
\hline Gruta do Vale Telheiro & Algarve & $37^{\circ} 10^{\prime} 13.1^{\prime \prime} \mathrm{N}, 8^{\circ} 02^{\prime} 05.3^{\prime \prime} \mathrm{W}$ & 239 & 17.0 \\
\hline Gruta da Senhora & Algarve & $37^{\circ} 06^{\prime} 20.5^{\prime \prime} \mathrm{N}, 7^{\circ} 46^{\prime} 35.2^{\prime \prime} \mathrm{W}$ & 85 & 17.8 \\
\hline
\end{tabular}

M5 and M20 microscopes and figures drawn with the aid of a camera lucida. Parts of specimens were mounted in micropreparations with Hoyer's liquid (Anderson 1954).

The ecological classification of species was made according to their degree of dependence on the subterranean environment using the Schiner-Racovitza system and following the same criteria as in Reboleira et al. (2011a): trogloxene species are those whose occurrence in caves is accidental; troglophiles, species with affinities to the subterranean environment and frequently found in it, but lacking troglomorphic traits, i.e., classical adaptations to subterranean life-style; and troglobionts, species that exhibit a combination of depigmentation and lack or reduction of eyes, and are found exclusively in subterranean ecosystems. 
All material was collected by A.S.P.S. Reboleira and has been deposited in the following collections:

MZUF = Museo di Storia Naturale dell'Università, Sezione di Zoologia "La Specola", Florence, Italy $\mathrm{SR}=$ Sofia Reboleira collection, Universidade de Aveiro, Portugal

ZMUC = Zoological Museum, Natural History Museum of Denmark, University of Copenhagen

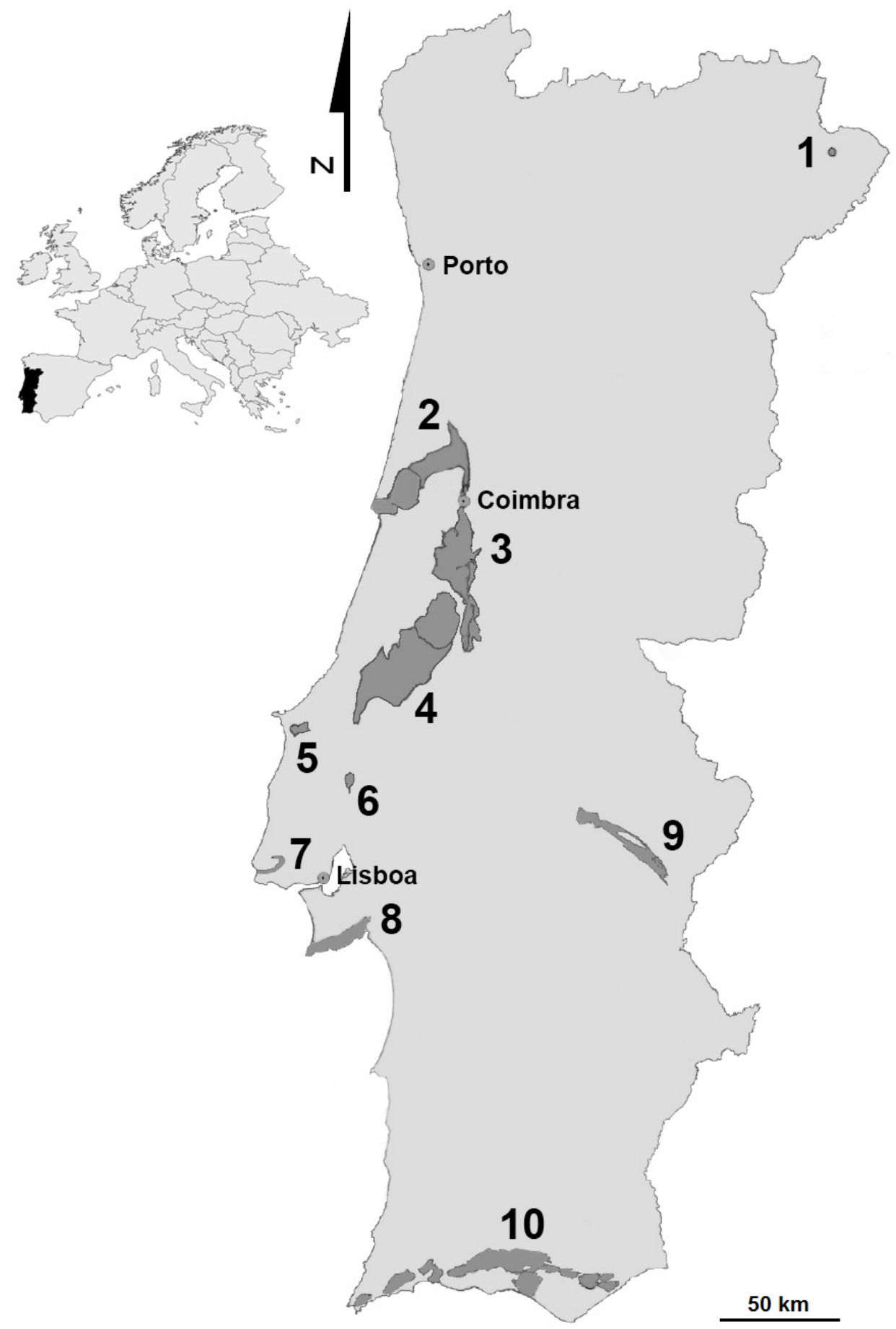

Fig. 1. Location of the main karst areas of Portugal. 1. Vimioso. 2. Cantenhede-Outil. 3. Sicó. 4. Estremenho. 5. Cesaredas. 6. Montejunto. 7. Lisbon Peninsula. 8. Arrábida. 9. Estremoz-Cano. 10. Algarve. 


\section{Results}

Class Malacostraca Latreille, 1802

Order Isopoda Latreille, 1817

Suborder Oniscidea Latreille, 1802

Family Trichoniscidae Sars, 1899

Genus Trichoniscoides Sars, 1899

Trichoniscoides broteroi Vandel, 1946

Trichoniscoides broteroi Vandel, 1946: 178, figs 22-26.

Trichoniscoides broteroi - Vandel 1948: 129, fig. 14; 1952a: 264, figs 2, 12. — Schmölzer 1965: 43, figs 120-122; 1971: 5, 78, 140, map 4. - Schmalfuss 2003: 302. — Reboleira et al. 2011a: 7, table 1.

\section{Records}

Gruta dos Alqueves, Coimbra, Sicó Massif (Vandel 1946).

\section{Remarks}

No specimens of this species were collected during our research. The type locality is now closed by the municipality and the whole surrounding area is urbanized.

\section{Distribution}

Presently known only from the type locality.

Trichoniscoides machadoi Vandel, 1946

Fig. 2A-C

Trichoniscoides machadoi Vandel, 1946: 168, figs 8-12.

Trichoniscoides machadoi - Vandel 1947: 270; 1948: 129, fig. 14; 1952a: 262, figs 2, 9. — Schmölzer 1965: 37, figs 79-82; 1971: 4, 75, 139, map 4. — Schmalfuss 2003: 303.

\section{Material examined}

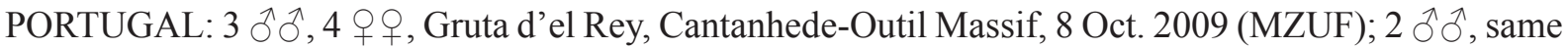
locality, 19 May 2009 (SR); 1 ð, 1 ค, Gruta da Senhora, Algarve Massif, 29 Dec. 2009 (MZUF); 1 ठૈ, 1 †, Gruta Abrigo Tomar I, Sicó Massif, 26 Sep. 2011 (ZMUC).

\section{Previous records}

Serra do Gerês, Terras de Bouro, Braga; Portunhos; Pampilhosa, Mealhada; Algar da Serra, Alvaiázere; Algar da Rocha, Souto, Sicó; Serra de Minde, Porto de Mós; Algarve da Terra da Rolha, Montejunto; Buracos Mineiros, Montejunto; Algarve $\mathrm{n}^{\circ} 1$ da Senhora das Neves, Montejunto; Serra do Montejunto; Cruz Quebrada, Oeiras; Gruta do Algar, Mexilhoeirinha, Lagos (Vandel 1946).

\section{Remarks}

The diagnostic features of this species, i.e., the male pereopod 7 and male pleopods 1 and 2 , are illustrated in Fig. 2 from specimens collected in Gruta d'el Rey.

\section{Distribution}

Species endemic to Portugal where it is widely distributed, from Serra do Gerês in the north to the Algarve in the south. 


\section{Ecological notes}

This species is both cavernicolous and endogean.

Trichoniscoides ouremensis Vandel, 1946

Trichoniscoides pseudomixtus ouremensis Vandel, 1946: 177, figs 20-21.

Trichoniscoides ouremensis - Vandel 1952a: 263, figs 2, 10. — Schmölzer 1965: 38, figs 91-92; 1971: 5, 76, 139, map 4. — Schmalfuss 2003: 304. — Reboleira et al. 2011a: 7, table 1.

\section{Records}

Lapa da Salgada, Fátima, Vila Nova de Ourém (Vandel 1946).

\section{Distribution}

Species endemic to Portugal, presently only known from the type locality.

Trichoniscoides serrai Cruz, 1993

Trichoniscoides serrai Cruz, 1993: 18, fig. 2a-h.

Trichoniscoides serrai - Schmalfuss 2003: 304.

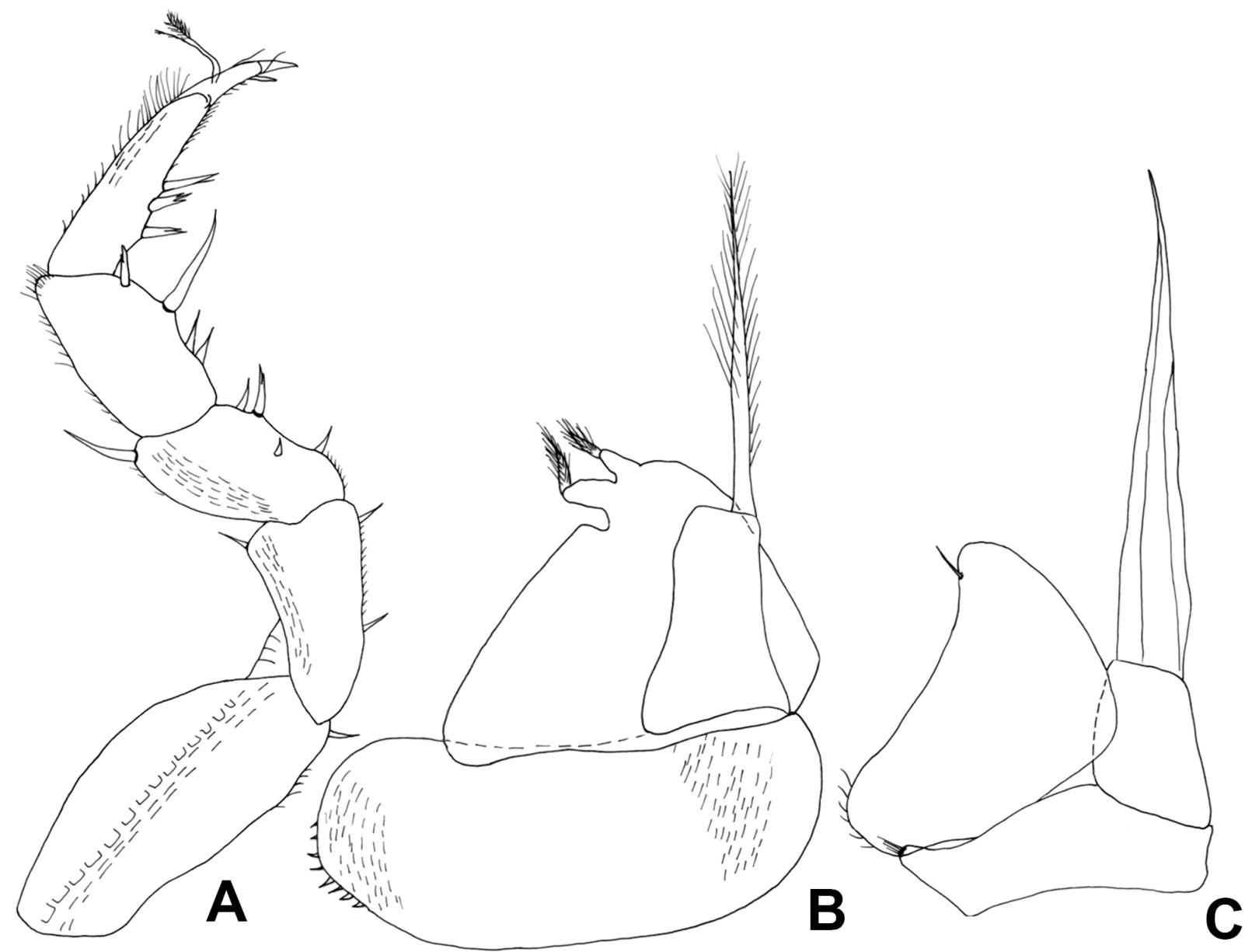

Fig. 2. Trichoniscoides machadoi Vandel, 1946 from Gruta d'el Rey, Cantanhede-Outil, ô. A. Pereopod 7. B. Pleopod 1. C. Pleopod 2. 


\section{Records}

Gruta de Santo Adrião, Trás-os-Montes, Miranda do Douro (Cruz 1993).

\section{Distribution}

Species endemic to northern Portugal, known only from the type locality.

Trichoniscoides subterraneus Vandel, 1946

Trichoniscoides machadoi subterraneus Vandel, 1946: 173, figs 13-15.

Trichoniscoides subterraneus - Vandel 1952a: 264, figs 2, 11. — Schmölzer 1965: 42, figs 116-117; 1971: 5, 77, 140, map 4. — Schmalfuss 2003: 304. — Reboleira et al. 2011a: 7, table 1.

\section{Records}

Gruta Alta do Cabeço dos Mosqueiros, Aljubarrota, Alcobaça (Vandel 1946).

\section{Distribution}

Species endemic to central Portugal, known only from the type locality.

Trichoniscoides meridionalis Vandel, 1946

Fig. 3A-C

Trichoniscoides pseudomixtus meridionalis Vandel, 1946: 175, figs 16-19.

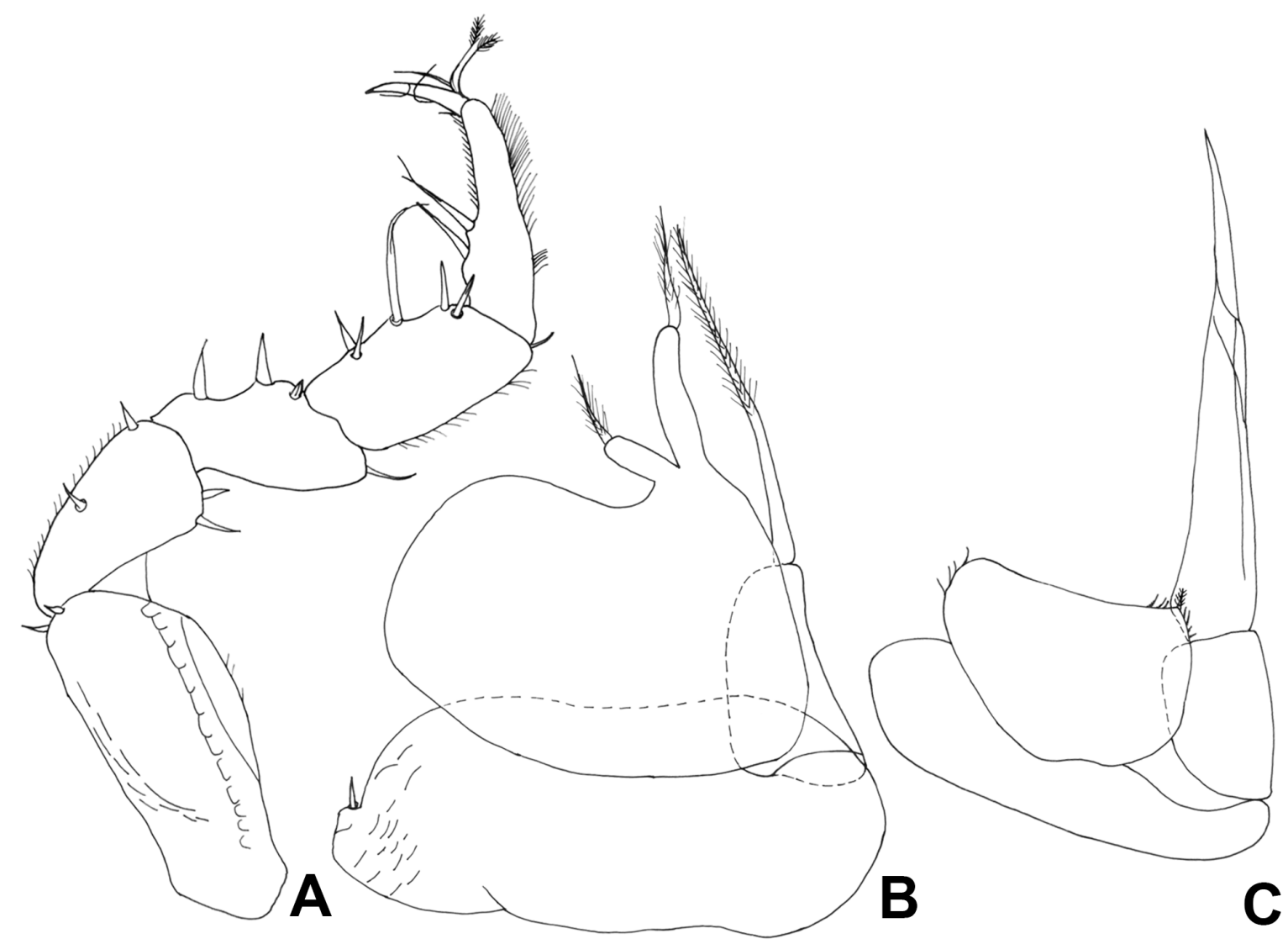

Fig. 3. Trichoniscoides meridionalis Vandel, 1946 from Gruta dos Moinhos, Velhos, Estremenho, ô. A. Pereopod 7. B. Pleopod 1. C. Pleopod 2. 
Trichoniscoides meridionalis - Vandel 1952a: 266, figs 2, 13. — Schmölzer 1965: 37, figs 83-84; 1971: 5, 75, 139, map 4. — Reboleira et al. 2011a: 7, table 1.

\section{Material examined}

PORTUGAL: $4 \widehat{\partial} \widehat{\partial}, 2$ $q$,, Gruta dos Moinhos Velhos, Estremenho Massif, 24 Mar. 2007 (MZUF);

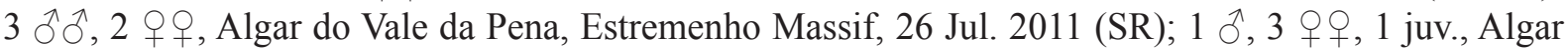
do Burro, Estremenho Massif, 5 May 2014 (MZUF); 1 ㅇ, Algar do Zé de Braga, Estremenho Massif,

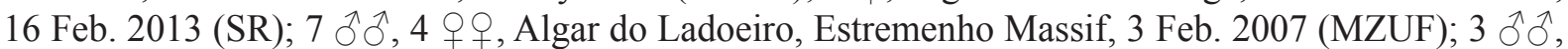
1 q, same locality, 6 Jan. 2007 (SR); 1 Oे, 1 , , 3 juvs, Gruta do Almonda, Estremenho Massif, 24 Aug. 2013

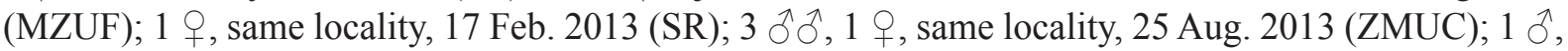
Gruta do Papagaio, Estremenho Massif, 5 Apr. 2014 (MZUF).

\section{Previous records}

Lapa da Chã de Cima, Porto de Mós, Leiria; Gruta das Alcobertas, Rio Maior, Santarém (Vandel 1946). Lapa dos Ladoeiros, Porto de Mós; Lapa da Ovelha, Serra de Minde, Santarém (Vandel 1952a).

\section{Distribution}

This species is restricted to the Estremenho karst massif, in central-western Portugal.

\section{Remarks}

This form was described by Vandel (1946) as a subspecies of Trichoniscoides pseudomixtus (Arcangeli, 1935), a species present in some caves of northeastern Spain. Vandel (1952a) elevated this form to species level. The male pereopod 7 and male pleopods 1 and 2 are illustrated in Fig. 3 from specimens collected in Gruta dos Moinhos Velhos.

\section{Ecological notes}

This species can be found from the entrances to the deepest parts of the caves, normally associated with decomposing wood. It is distributed along the three main subunits of the Estremenho Massif, being the only troglobiotic oniscidean so far known from this large karst area. Contrary to other troglobiotic arthropods from the same massif, it does not present closely related species along the three subunits (Reboleira 2007; Reboleira et al. 2009). The biocoenosis of this karst area includes other troglobionts, i.e., the spider Nesticus lusitanicus Fage, 1931, the campodeid Podocampa cf. fragiloides Silvestri, 1932, and the ground beetles Trechus gamae Reboleira \& Serrano, 2009, T. lunai Reboleira \& Serrano, 2009 and T. machadoi Jeannel, 1941 (Reboleira \& Ortuño 2011; Reboleira et al. 2010b).

Trichoniscoides bellesi Reboleira \& Taiti sp. nov. urn:1sid:zoobank.org:act:FE37F766-5E77-430F-87C2-C5CB28A78D5D

Figs $4 \mathrm{~A}-\mathrm{G}, 5 \mathrm{~A}-\mathrm{E}, 6 \mathrm{~A}-\mathrm{D}$

\section{Diagnosis}

A blind and colourless Trichoniscoides characterised by the male pleopod 1 exopod having a broadly rounded outer margin and two equal distal lobes, and the male pleopod 2 endopod having a distal article thickset for $2 / 3$ of its length, ending with a narrow point.

\section{Etymology}

The new species is named after Prof. Xavier Bellés for his invaluable contribution to the synthesis of knowledge on the subterranean fauna from the Iberian Peninsula. 


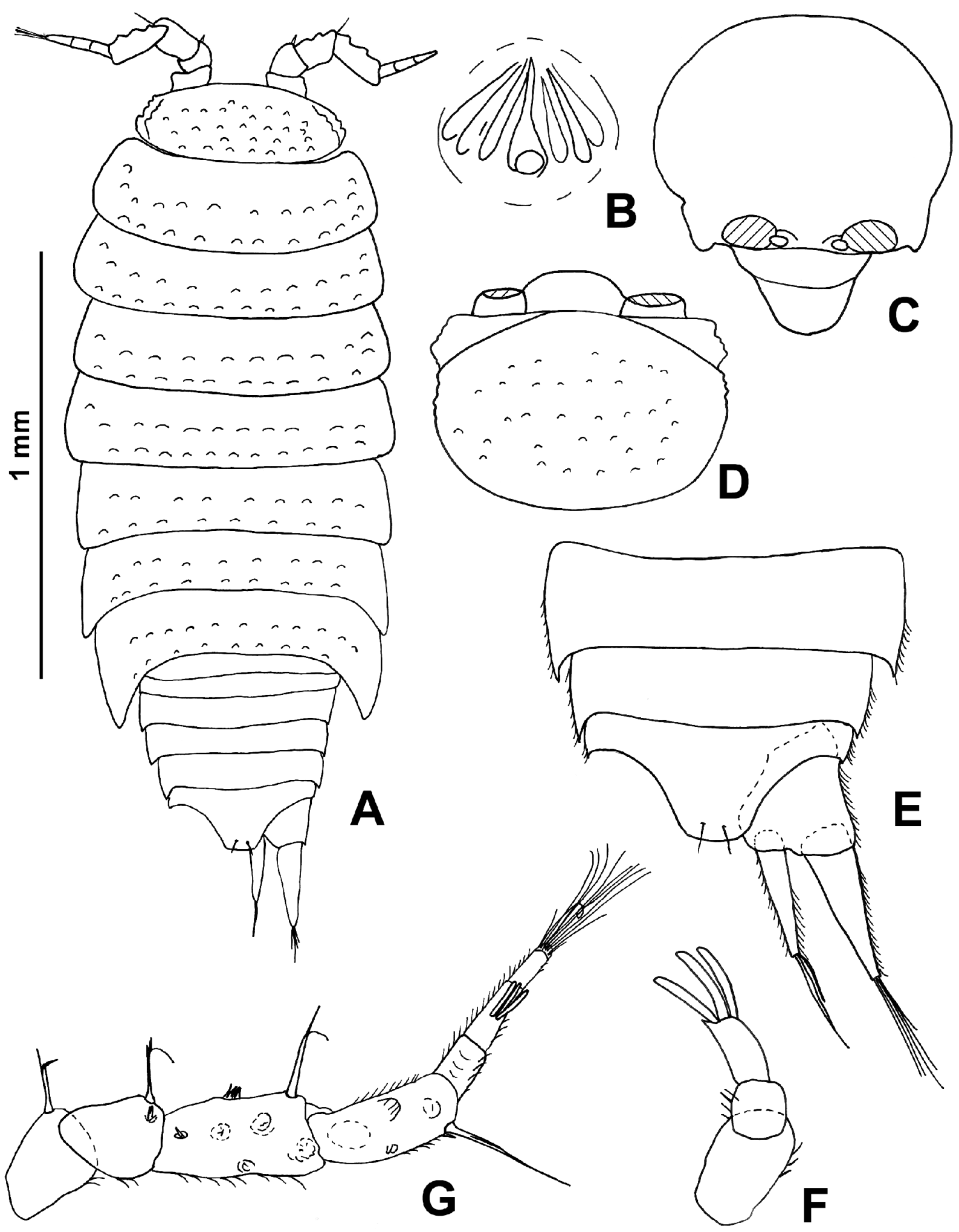

Fig. 4. Trichoniscoides bellesi Reboleira \& Taiti sp. nov. from Algar do Javali, Montejunto. - Paratype, q. A. Adult specimen in dorsal view. B. Dorsal scale-seta. C. Cephalon in frontal view. D. Cephalon in dorsal view. - Paratype, §. E. Pleonites 4, 5, telson and right uropod. F. Antennula. G. Antenna. 


\section{Material examined}

\section{Holotype}

PORTUGAL: §̊, Algar do Javali, Montejunto Massif, 26 Dec. 2012 (MZUF).

\section{Paratypes}

PORTUGAL: $1 \hat{\jmath}, 1$, same data as holotype (MZUF).

\section{Description}

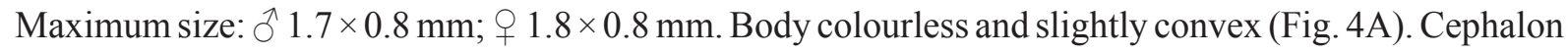
and pereon with granulated dorsal surface; granules on pereonites arranged in double rows; each granule bearing a triangular scale-seta (Fig. 4B) on top. Cephalon (Fig. 4C-D) with quadrangular frontal lateral lobes not protruding frontwards. Eyes absent. Pereonites 1-4 (Fig. 4A) with rounded posterior corners; pereonites 5-7 (Fig. 4A) with epimera pointing backwards. Pleon (Fig. 4A, E) narrower than pereon; pleonites $3-5$ with small epimera and short posterior points. Telson (Fig. 4E) more than twice as wide as
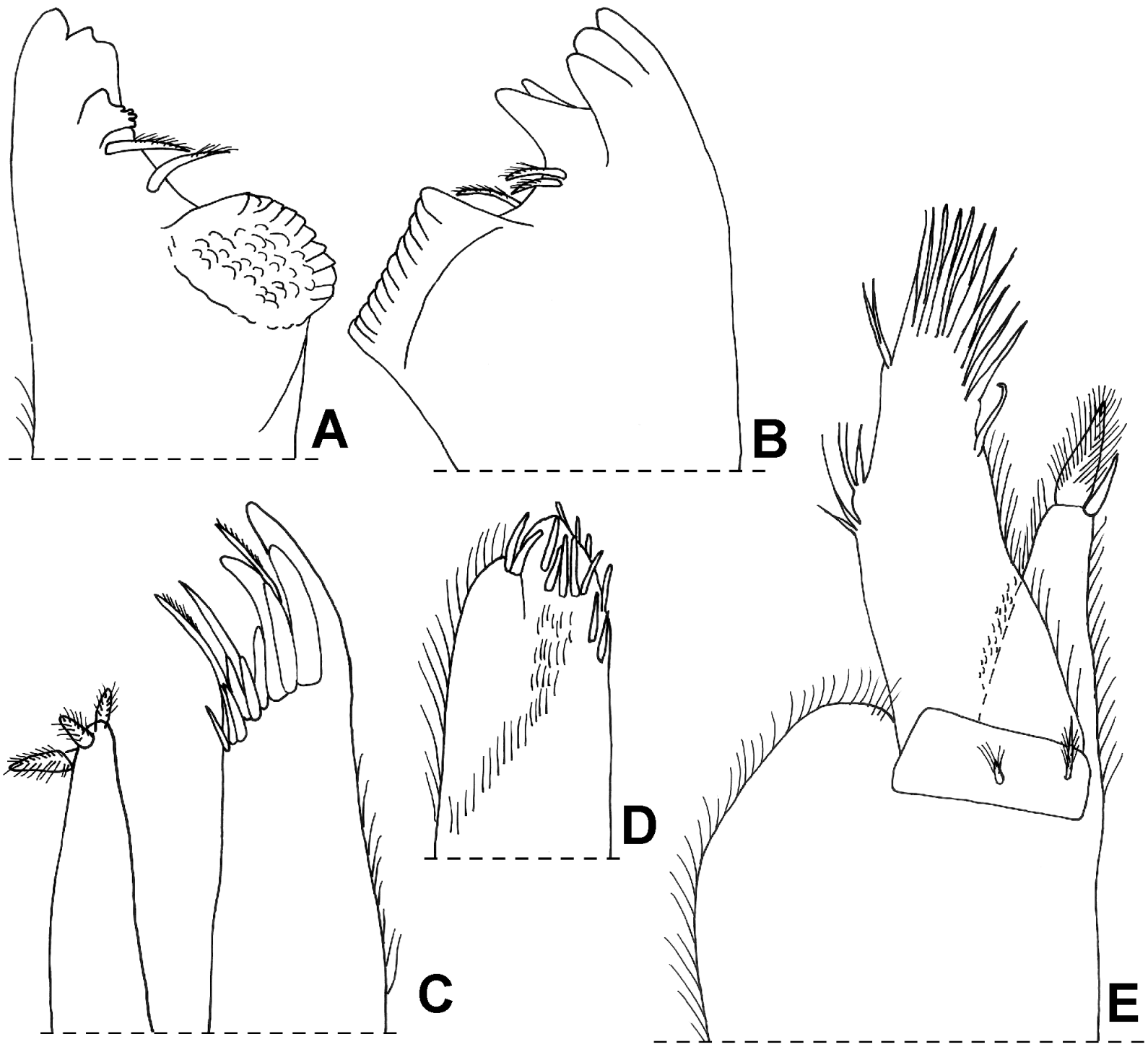

Fig. 5. Trichoniscoides bellesi Reboleira \& Taiti sp. nov. from Algar do Javali, Montejunto, paratype,, . A. Right mandible. B. Left mandible. C. Maxillula. D. Maxilla. E. Maxilliped. 
long, distal part trapezoidal with concave sides and slightly convex apex. Antennula (Fig. 4F) with three articles; third article with distinct spine and three long aesthetascs at apex. Antenna (Fig. 4G) with fifth article of peduncle shorter than flagellum; flagellum with three articles, with three long aesthetascs on second article. Mandibles (Fig. 5A-B) with two penicils on the right and three on the left; molar process without penicils. Maxillula (Fig. 5C) with inner branch bearing three penicils at apex, proximal one distinctly longer than other two; outer branch with 11 teeth and two thin stems, one among outer group and one among inner group of teeth. Maxilla (Fig. 5D) apically bilobed, with outer lobe smaller than inner one; inner lobe with several long, stout setae. Maxilliped (Fig. 5E) endite triangular, with stout penicil at apex; palp distally rounded, with long setae, basal article with two short, compound setae.

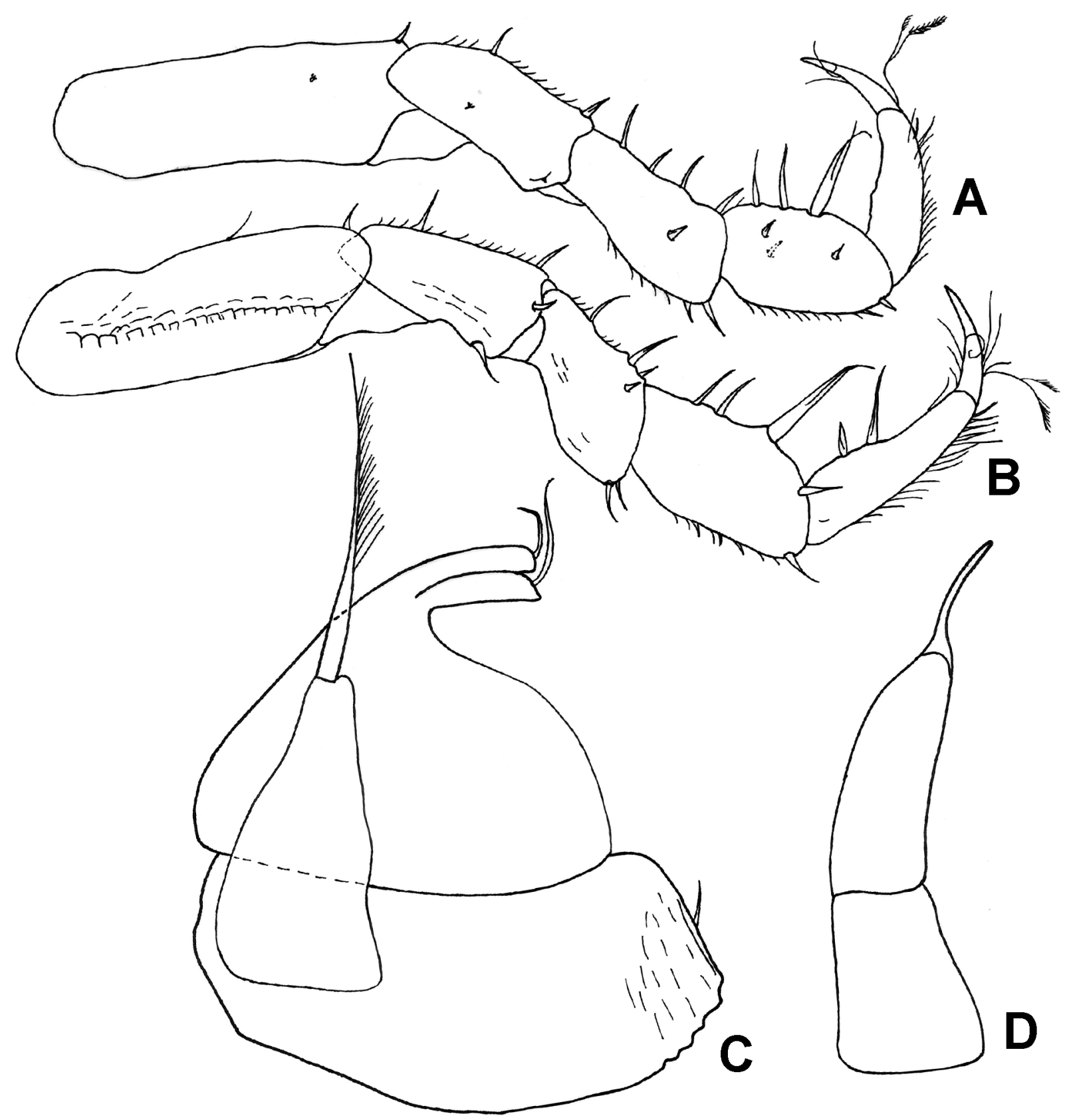

Fig. 6. Trichoniscoides bellesi Reboleira \& Taiti sp. nov. from Algar do Javali, Montejunto, paratype, ô. A. Pereopod 1. B. Pereopod 7. C. Pleopod 1. D. Pleopod 2 endopod. 
Uropod (Fig. 4E) with exopod distinctly longer than endopod; exopod with several long, pointed setae and endopod with a long and a short seta at apex.

MALE. Pereopod 1 (Fig. 6A) and pereopod 7 (Fig. 6B) with no particular modifications. Pleopod 1 (Fig. 6C) exopod almost as long as wide, with broadly rounded outer margin and two equal distal lobes each bearing a short seta at apex; endopod with triangular and flagelliform basal article and setose distal article. Pleopod 2 exopod missing in the specimen examined; endopod (Fig. 6D) biarticulated, distal article about twice as long as basal one, thickset for first $2 / 3$ and ending with narrow point.

\section{Remarks}

In the shape of the male pleopod 2 exopod, with a thickset distal article ending in a narrow point, the new species is similar to Trichoniscoides lusitanus Vandel, 1946, T. broteroi and T. heroldi Vandel, 1952. It differs from T. lusitanus, an epigean species from north-western Spain and northern Portugal, in lacking eyes and pigment, in the male pleopod 1 endopod having a triangular basal article, and in the male pleopod 2 endopod having a stouter distal article ending in a shorter point; from T. broteroi in lacking the hook on the male pereopod 7 merus, and in the triangular shape of the basal article of the male pleopod 1 endopod; from $T$. heroldi, an epigean species from eastern France, in the lack of eyes and the shape of the male pleopod 1.

\section{Ecological notes}

Trichoniscoides bellesi sp. nov. is typically a troglobiotic species, lacking eyes and body pigment. It was discovered in the deepest and most thermally insulated parts of Algar do Javali, around $10 \mathrm{~m}$ deep. Javali is currently the richest cave of the Montejunto karst massif. Four other caves in the same massif were also sampled (Algar do Escorpião, Ralo das Fontaínhas, Algar da Terra da Rolha and Buracos Mineiros) without recovering any specimens of $T$. bellesi. The subterranean community of Algar do Javali includes other troglobiotic species, such as the campodeid Podocampa $\mathrm{cf}$. fragiloides, a species of the oniscidean genus Paraschizidium (see below), the ground beetle Trechus tatai Reboleira \& Ortuño, 2010, a new pselaphid beetle, and the pseudoscorpions Chthonius cardosoi Zaragoza, 2012 and Roncocreagris occidentalis Zaragoza \& Reboleira, 2013 (Reboleira et al. 2010a, 2013c).

Trichoniscoides sicoensis Reboleira \& Taiti sp. nov. urn:1sid:zoobank.org:act:FCBE373B-42CE-4305-A932-28D88355FFB8

Figs $7 \mathrm{~A}-\mathrm{G}, 8 \mathrm{~A}-\mathrm{E}, 9 \mathrm{~A}-\mathrm{E}$

\section{Diagnosis}

A blind and colourless Trichoniscoides characterised by the male pereopod 7 merus having a lobe on the mid-sternal margin, the male pleopod 1 exopod having a broadly rounded outer margin and two unequal setae, the endopod having a fusiform distal article with a distinct circular suture in the middle, and the male pleopod 2 endopod having thickset distal article bearing two short triangular lobes and two setae at the apex.

\section{Etymology}

The new species is named after the Sicó karst area, where the species occurs.

\section{Material examined}

\section{Holotype}

PORTUGAL: §̂, Gruta da Cerâmica, Sicó Massif, 21 Mar. 2010 (MZUF).

\section{Paratypes}

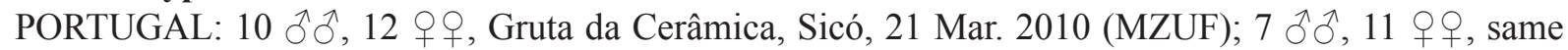

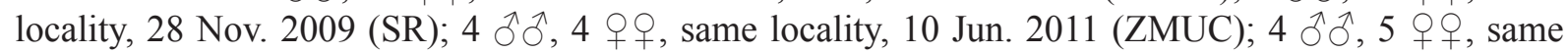


locality, 2 Mar. 2013 (MZUF); 12 $\widehat{\partial}, 8$ q , Gruta da Senhora da Estrela, Sicó, 20 Nov. 2009 (MZUF);

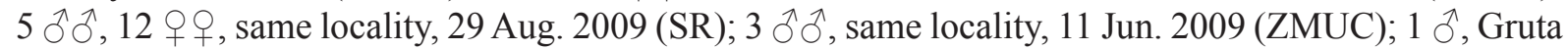
do Soprador do Carvalho, Sicó, 12 Jun. 2011 (SR); 2 ふふ, 3 우우, same locality, 8 Jun. 2013 (MZUF);

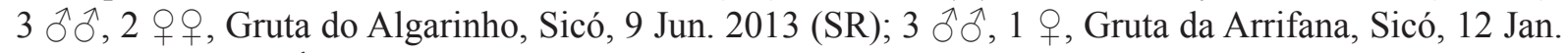
2013 (ZMUC); 1 ภ̂, 2 우, Gruta de São Simão, Sicó, 30 Nov. 2013 (MZUF).

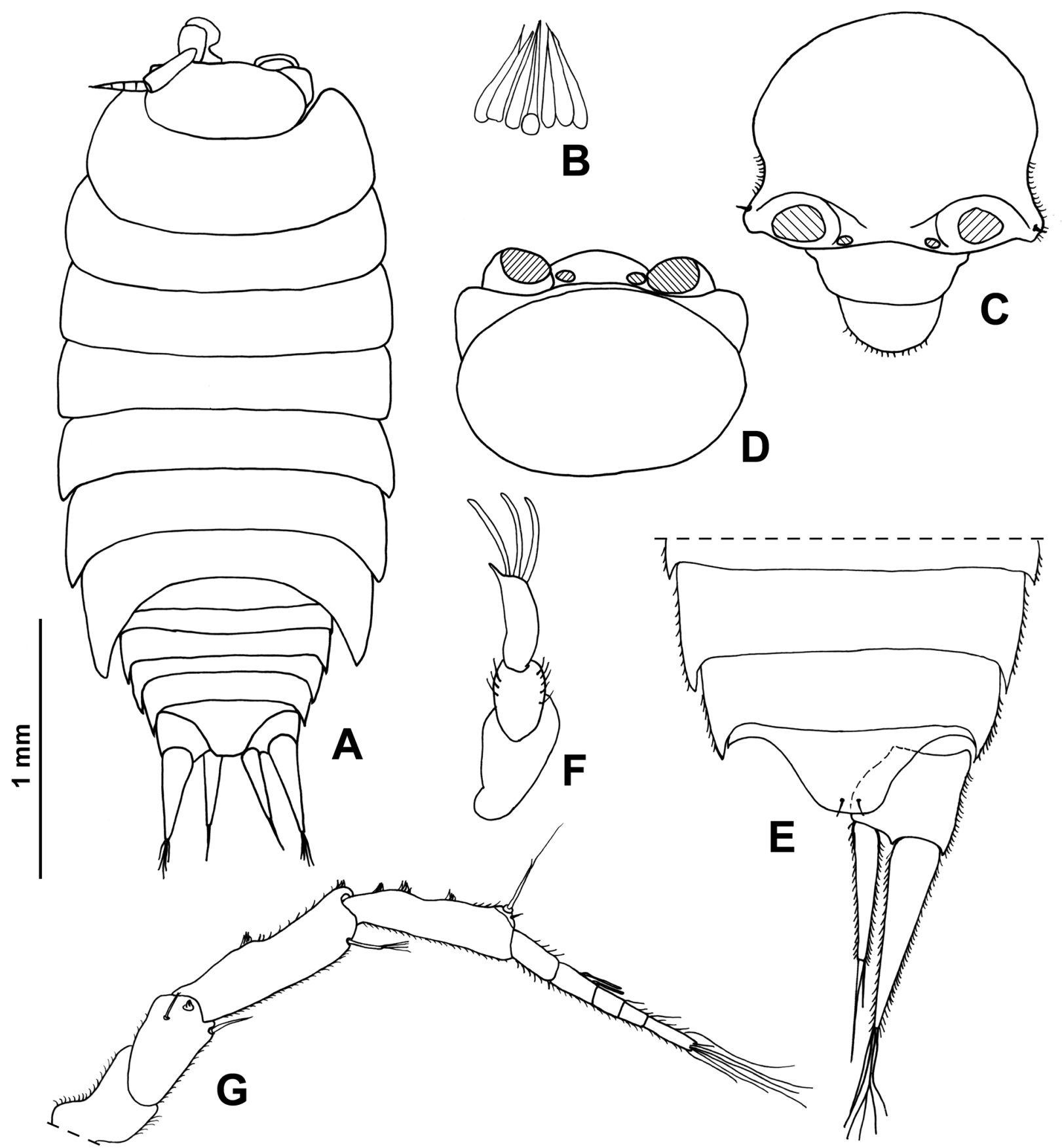

Fig. 7. Trichoniscoides sicoensis Reboleira \& Taiti sp. nov. from Gruta da Cerâmica, Sicó. — Paratype, ․ A. Specimen in dorsal view. - Paratype, ô. B. Dorsal scale-seta. C. Cephalon in frontal view. D. Cephalon in dorsal view. E. Pleonites 4, 5, telson and right uropod. F. Antennula. G. Antenna. 


\section{Description}

Maximum size: $\widehat{\jmath} 3.5 \times 1.2 \mathrm{~mm}$; $+3.9 \times 1.2 \mathrm{~mm}$. Body colourless and slightly convex (Fig. 7A). Dorsum smooth, with scattered triangular scale-setae (Fig. 7B). Cephalon (Fig. 7C-D) with rounded frontal lateral lobes not protruding frontwards. Eyes absent. Pereonites 1-4 (Fig. 7A) with rounded posterior corners; pereonites 5-7 (Fig. 7A) with epimera pointing backwards. Pleon (Fig. 7A, E) narrower than pereon; pleonites 3-5 with small epimera and short posterior points. Telson (Fig. 7E) about three times as wide as long, with distal part trapezoidal with concave sides. Antennula (Fig. 7F) with three articles; third article with distinct spine and three long aesthetascs at apex. Antenna (Fig. 7G) with fifth article of peduncle shorter than flagellum; flagellum with five articles with two long aesthetascs on second article. Mandibles (Fig. 8A-B) with two penicils on the right and three on the left; molar process without penicils. Maxillula (Fig. 8C) with inner branch bearing three penicils at apex, inner one distinctly longer than other two; outer branch with 11 teeth and two thin stems. Maxilla (Fig. 8D) apically bilobed and setose, with outer lobe smaller than inner one; inner lobe with several long stout setae. Maxilliped (Fig. $8 \mathrm{E}$ ) endite triangular, with stout triangular penicil at apex; palp distally rounded, long setae, and basal

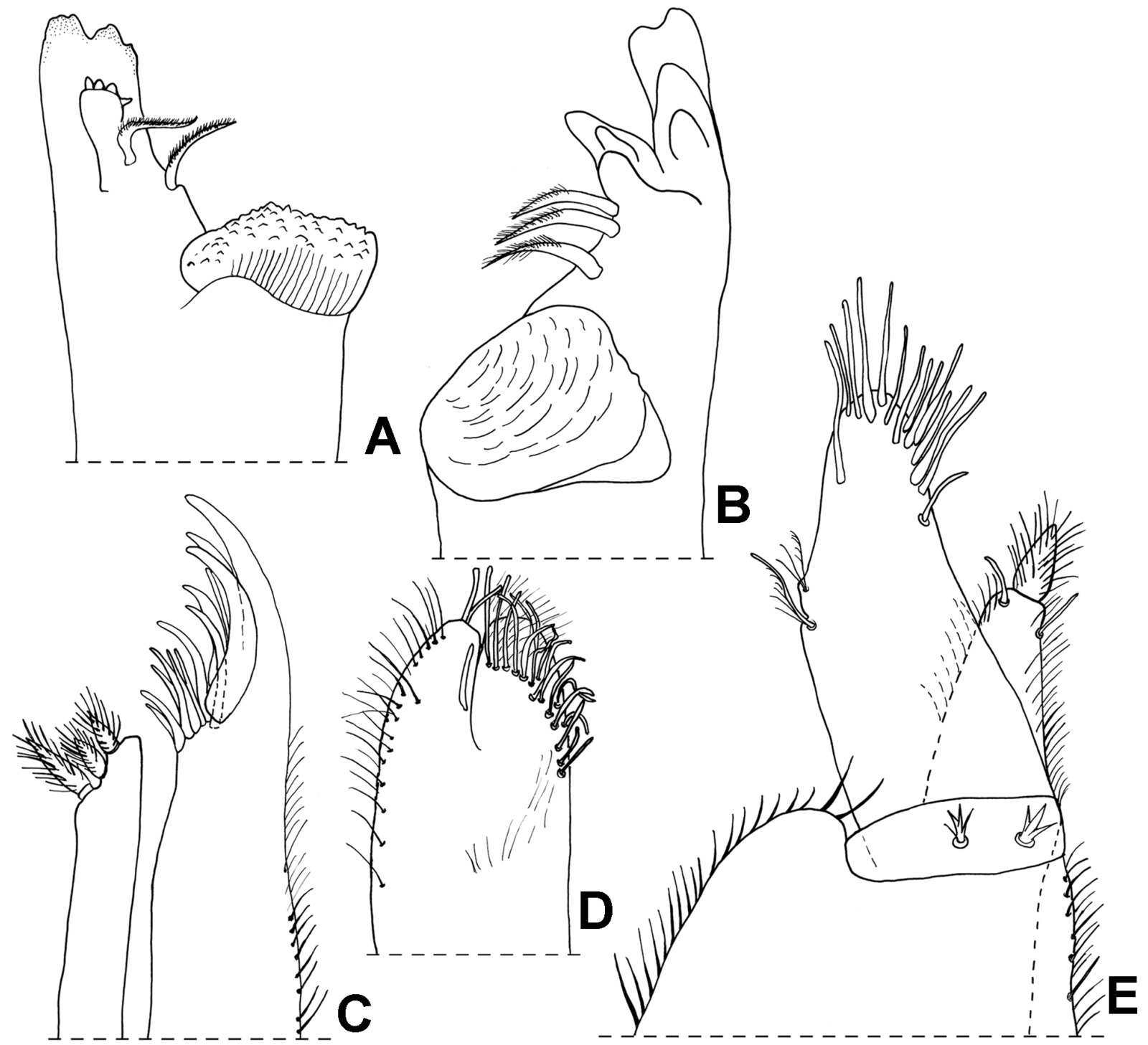

Fig. 8. Trichoniscoides sicoensis Reboleira \& Taiti sp. nov. from Gruta da Cerâmica, Sicó, paratype, Ø̃. A. Right mandible. B. Left mandible. C. Maxillula. D. Maxilla. E. Maxilliped. 


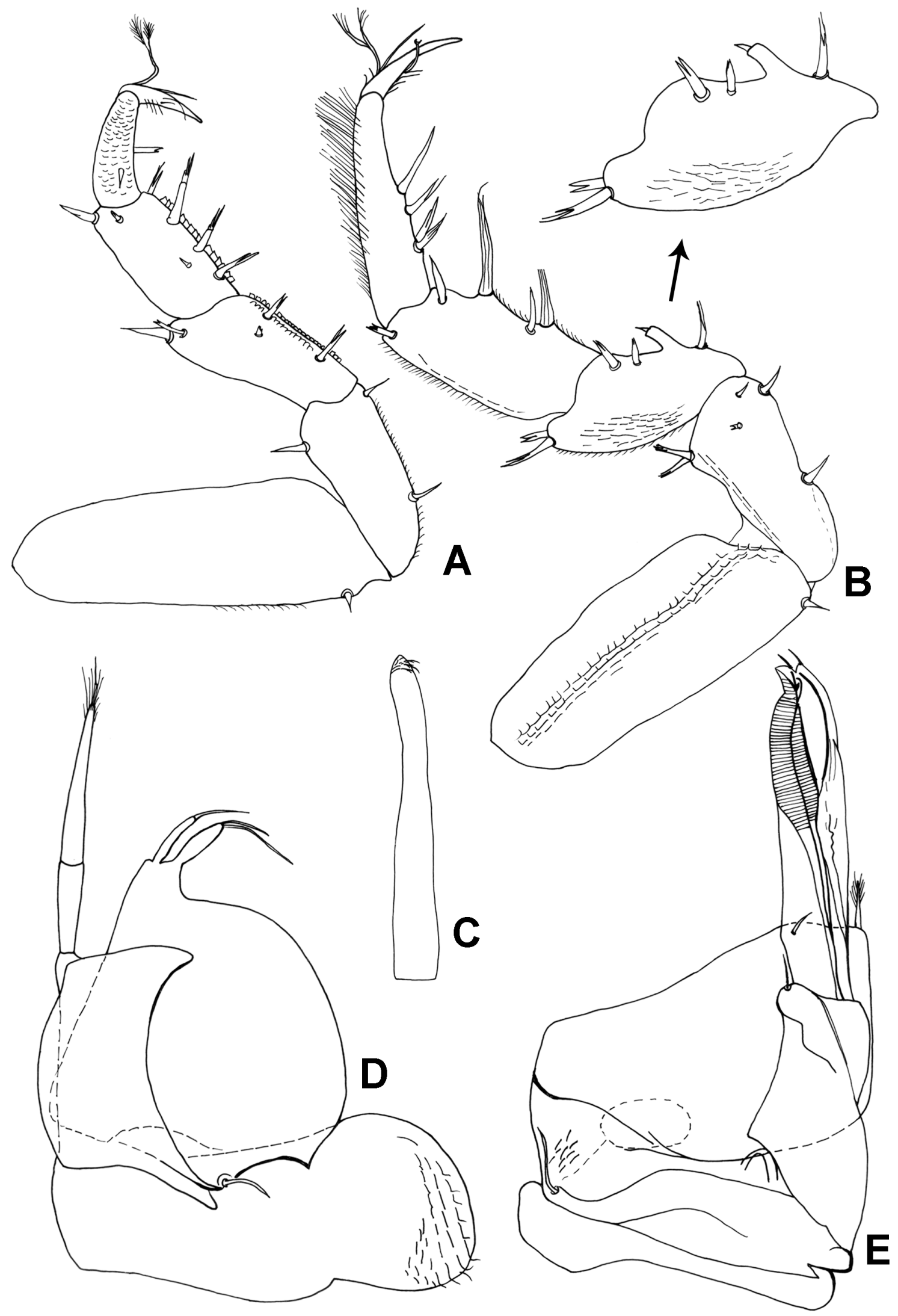

Fig. 9. Trichoniscoides sicoensis Reboleira \& Taiti sp. nov. from Gruta da Cerâmica, Sicó, paratype, Õ. A. Pereopod 1. B. Pereopod 7. C. Genital papilla. D. Pleopod 1. E. Pleopod 2. 
article with two short compound setae. Uropod (Fig. 7E) with exopod distinctly longer than endopod and more distally inserted; exopod with several long, pointed setae and endopod with a long and a short seta at apex.

MALE. Pereopods 1 (Fig. 9A) to 3 with an area of short quadrangular scales on sternal margin of carpus and merus. Pereopod 7 (Fig. 9B) merus with distinct cylindrical lobe, with short seta at apex on mid-sternal margin. Genital papilla (Fig. 9C) fusiform. Pleopod 1 (Fig. 9D) exopod as long as wide, with broadly rounded outer margin and two unequal setae on distal lobe; endopod with basal article quadrangular with convex inner margin and concave outer margin, distal article fusiform with distinct suture in middle and setose apex. Pleopod 2 (Fig. 9E) exopod trapezoidal with large seta at apex; endopod biarticulated, distal article about 1.5 times as long as basal one, thickset, with two short triangular lobes and setae at apex.

\section{Remarks}

This new species is tentatively included in the genus Trichoniscoides since it has all the characters of the genus, except for the distal article of the male pleopod 1 endopod, which shows a distinct circular suture in the middle, and the thickset distal part of the male pleopod 2 endopod. These characters are present also in an epigean species described by Gregory et al. (2012: 7, fig. 4) as "? Trichoniscoides species C" from Avión, valley of Río Valdeiras, Orense, north-western Spain, and Castanheira, Viana do Castelo, northern Portugal. The new species differs from the one recorded by Gregory et al. (2012) in the shape of the basal article of the male pleopod 1 endopod and of the distal part of the male pleopod 2 endopod. Trichoniscoides sicoensis Reboleira \& Taiti sp. nov., together with the species recorded by Gregory et al. (2012), might belong to a distinct genus, but this can only be confirmed when other species with similar characters are found. For the presence of a lobe on the mid-sternal margin of the male pereopod 7 merus, the new species also resembles T. broteroi, from which it is distinguishable by the shape of the male pleopods 1 and 2. A hook-like lobe on the sternal margin of the male pereopod 7 merus is present also in the "aquitano-languedocien" group of species (sensu Vandel 1960a), but in the species of this group the lobe is near the base instead of being on the mid-part of the sternal margin.

\section{Ecological notes}

This species seems to be endemic to caves of the Sicó karst area. In Gruta do Soprador do Carvalho one specimen was collected under a stone completely submerged in the cave stream. Despite the amphibian behaviour and submersion tolerance, this species is mostly found in the superficial parts of caves, where roots are abundant. Several troglobiotic species are known to share this habitat with $T$. sicoensis Reboleira \&Taiti sp. nov.: the pseudoscorpions Roncocreagris blothroides (Beier, 1962), R. borgesi Zaragoza \& Reboleira, 2013 and R. cavernicola Vachon, 1946; the millipede Scutogona minor Enghoff \& Reboleira, 2013; the woodlice T. broteroi, Miktoniscus longispina Reboleira \& Taiti sp. nov. and Porcellio cavernicolus; and the rove beetle Domene lusitanica Reboleira \& Oromí, 2011 (Reboleira et al. 2011b, 2013b; Enghoff \& Reboleira 2013a).

Genus Metatrichoniscoides Vandel, 1942

Metatrichoniscoides salirensis Reboleira \& Taiti sp. nov. urn:lsid:zoobank.org:act:7E09D1C5-19F8-44DF-A1AE-B2D741C411AE

Figs $10 \mathrm{~A}-\mathrm{G}, 11 \mathrm{~A}-\mathrm{E}, 12 \mathrm{~A}-\mathrm{E}$

\section{Diagnosis}

A blind and colourless Metatrichoniscoides characterised by the male pleopod 1 exopod having two long distal setae subequal in length, and the male pleopod 2 endopod having a thickset distal article, ending in a thinner sinuous part with a beak-like small lobe medially directed. 


\section{Etymology}

The new species is named after Gruta de Salir, the cave where the specimens were collected, in the municipality of Caldas da Rainha.

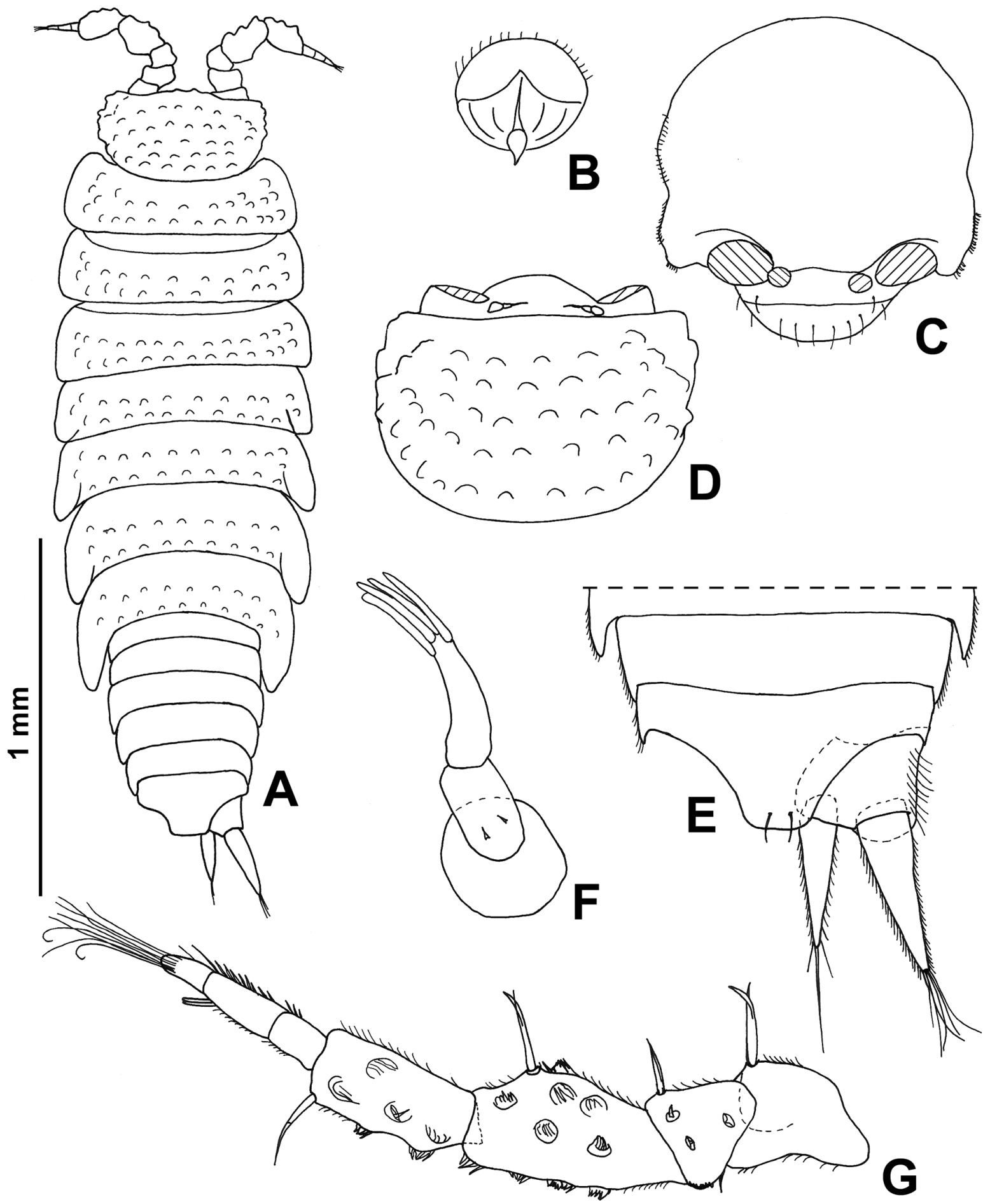

Fig. 10. Metatrichoniscoides salirensis Reboleira \& Taiti sp. nov. from Gruta de Salir, Caldas da Rainha typhonic valley. - Paratype,, . A. Adult specimen in dorsal view. B. Dorsal scale-seta. C. Cephalon in frontal view. D. Cephalon in dorsal view. - Paratype, $\widehat{\jmath}$. E. Pleonites 4, 5, telson and right uropod. F. Antennula. G. Antenna. 
Material examined

Holotype

PORTUGAL: §̊, Gruta de Salir, Salir do Porto, Caldas da Rainha, 26 Dec. 2012 (MZUF).

Paratypes

PORTUGAL: $1 \hat{\delta}, 2$ 우, same data as holotype (MZUF); $1 \hat{\jmath}, 2$ 우, same data as holotype (SR).
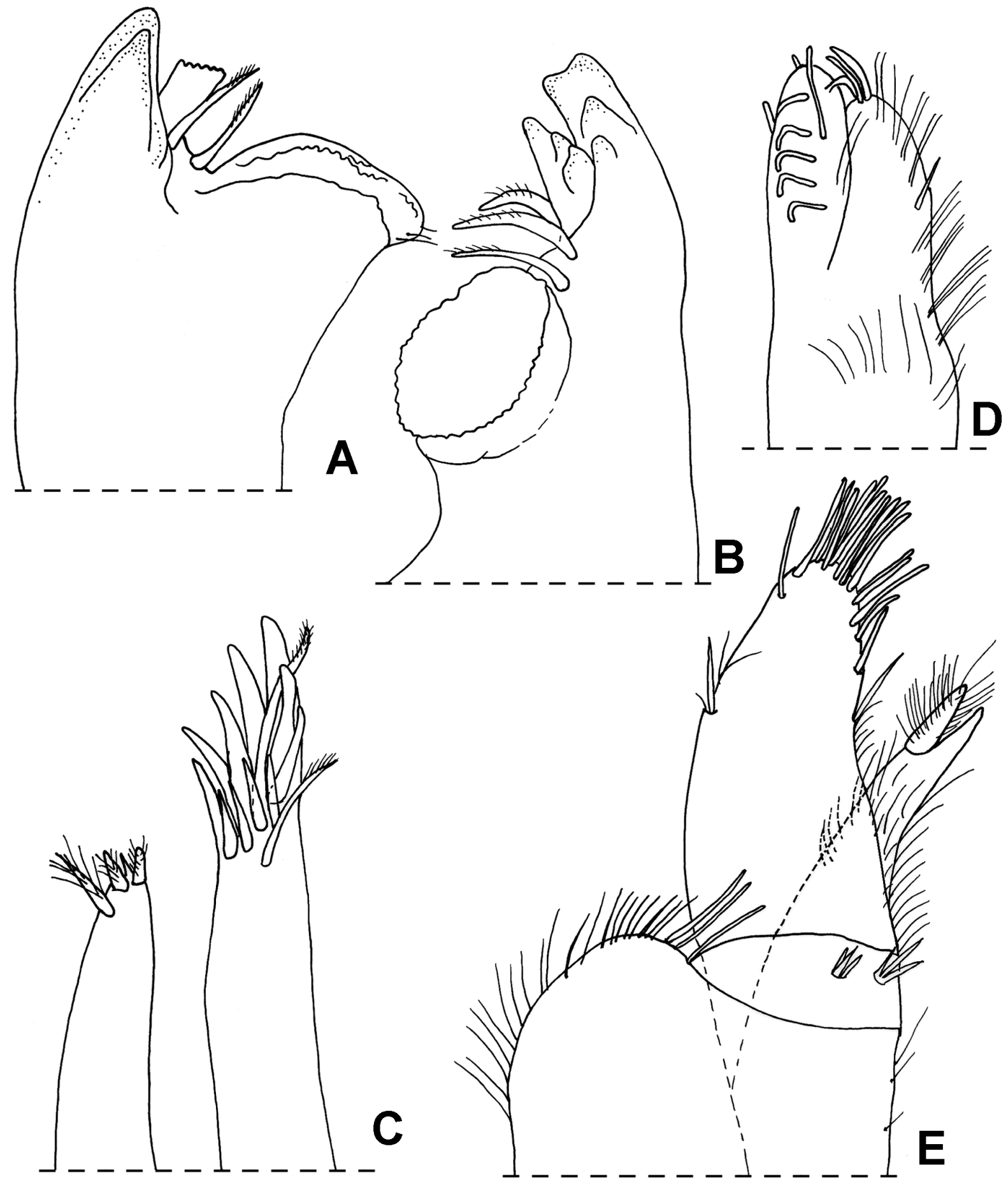

Fig. 11. Metatrichoniscoides salirensis Reboleira \& Taiti sp. nov. from Gruta de Salir, Caldas da Rainha, paratype, ô. A. Right mandible. B. Left mandible. C. Maxillula. D. Maxilla. E. Maxilliped. 


\section{Description}

Maximum size: of and $+2.2 \times 0.8 \mathrm{~mm}$. Body colourless, elongated and slightly convex (Fig. 10A). Cephalon and pereon with granulated dorsal surface; granules on pereonites arranged in double rows; each granule bearing a triangular scale-seta (Fig. 10B). Cephalon (Fig. 10C-D) with no frontal lateral lobes. Eyes absent. Pereonites 1-4 (Fig. 10A) with rounded posterior corners; pereonites 5-7 (Fig. 10A) with epimera directed backwards. Pleon (Fig. 10A,E) narrower than pereon; pleonites 3-5 with small epimera and short posterior points. Telson (Fig. 10E) twice as wide as long, with distal part trapezoidal with concave sides. Antennula (Fig. 10F) with three articles; third article distinctly longer than first

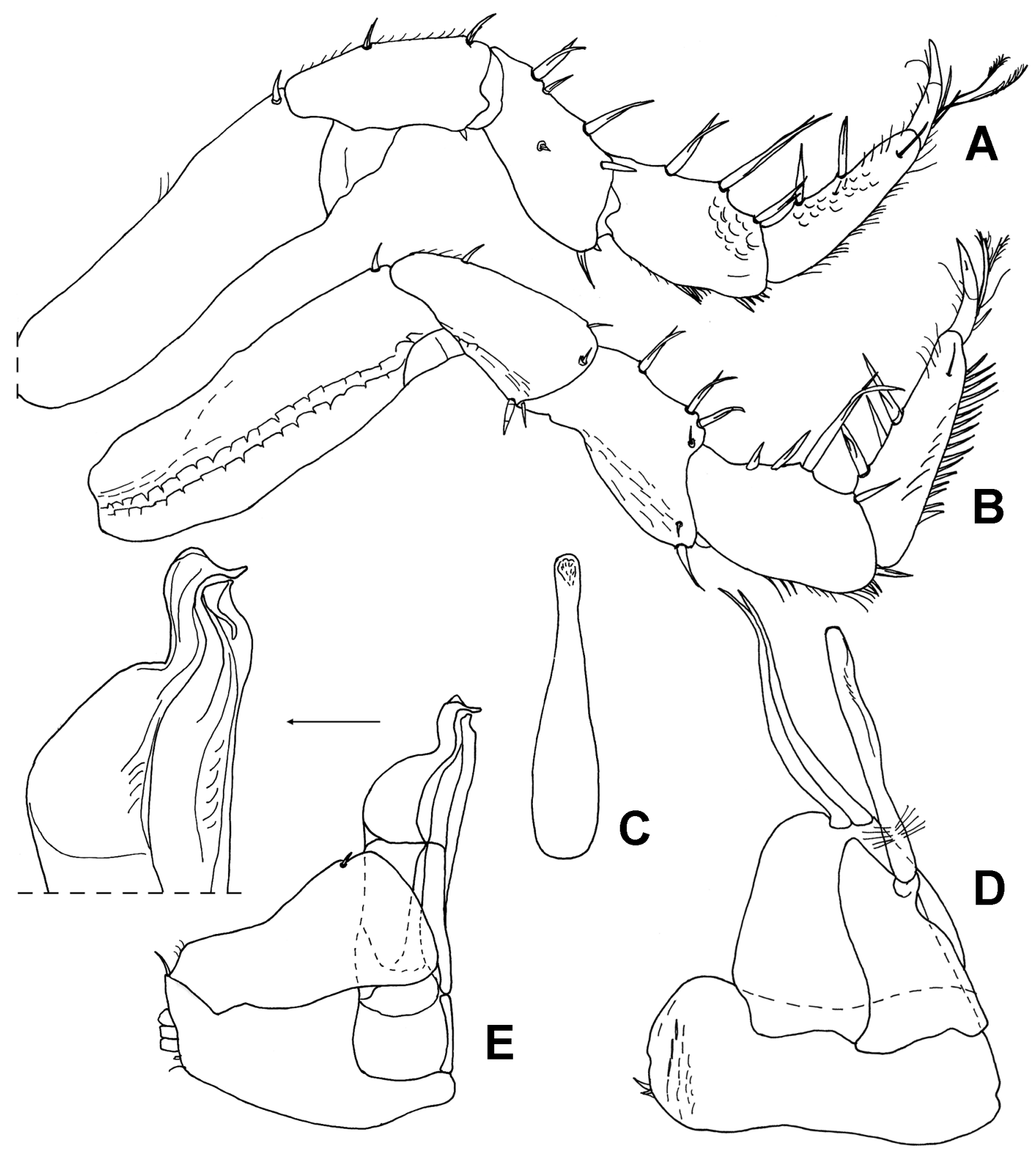

Fig. 12. Metatrichoniscoides salirensis Reboleira \& Taiti sp. nov. from Gruta de Salir, Caldas da Rainha, paratype, ô. A. Pereopod 1. B. Pereopod 7. C. Genital papilla. D. Pleopod 1. E. Pleopod 2. 
and second and bearing four long aesthetascs at apex. Antenna (Fig. 10G) with fifth article of peduncle slightly shorter than flagellum; flagellum with three articles, with two aesthetascs on second article. Mandibles (Fig. 11A-B) with two penicils on the right and three on the left; molar process without penicils. Maxillula (Fig. 11C) with inner branch bearing three short penicils at apex; outer branch with 11 teeth and two thin stems. Maxilla (Fig. 11D) apically bilobed, with outer lobe shorter than inner one; inner lobe with some long, stout setae near medial margin. Maxilliped (Fig. 11E) endite triangular, ending with triangular point and subapical penicil; palp distally rounded, with long setae, and basal article with two short compound setae. Uropod (Fig. 10E) with exopod slightly longer than endopod; exopod with several long, pointed setae and endopod with long seta at apex.

MALE. Pereopod 1 (Fig. 12A) and pereopod 7 (Fig. 12B) with no peculiar modifications. Genital papilla (Fig. 12C) fusiform, with rounded apex. Pleopod 1 (Fig. 12D) exopod as long as wide, with broadly rounded apical margin bearing two long setae of equal length; endopod with basal article triangular, batonlike distal article inserted on medial margin of basal article. Pleopod 2 (Fig. 12E) exopod trapezoidal, with short seta at apex; endopod biarticulated, distal article thickset, ending in thinner sinuous part with beak-like small lobe medially directed.

\section{Remarks}

Until now the genus Metatrichoniscoides included only four species (Schmalfuss 2003): M. leydigii (Weber, 1880) from western France, Belgium, the Netherlands, western Germany and greenhouses in the Czech Republic, Sweden and Finland; M. nemausiensis Vandel, 1942 and M. fouresi Vandel, 1950 from France; and M. celticus Oliver \& Trew, 1981 from Wales (Vandel 1942; Oliver \& Trew 1981). Metatrichoniscoides salirensis Reboleira \& Taiti sp. nov. is readily distinguished from all the other species in the genus by the male pleopod 1 exopod bearing two long setae and the peculiar shape of the male pleopod 2 endopod. This represents the first record of the genus for Portugal and the Iberian Peninsula.

\section{Ecological notes}

Gruta de Salir is a peculiar, beautiful cave located near the sea, with a genesis related to previous sea levels, evidenced by the presence of marine sand in the lowest parts. This is the first troglobiotic species known from this cave and this karst area.

Genus Troglonethes Cruz, 1989

Troglonethes olissipoensis Reboleira \& Taiti sp. nov. urn:1sid:zoobank.org:act:7E09D1C5-19F8-44DF-A1AE-B2D741C411AE

Figs $13 \mathrm{~A}-\mathrm{G}, 14 \mathrm{~A}-\mathrm{E}, 15 \mathrm{~A}-\mathrm{D}$

\section{Diagnosis}

A species of Troglonethes characterised by the antenna having five flagellar articles, the male pleopod 1 exopod triangular, as wide as long, and the male pleopod 2 endopod with the distal article bearing a basal and a distal hook-like process.

\section{Etymology}

The new species is named after Olissipo, the old name of Lisbon, on the peninsula of which the Gruta de Alvide is located.

\section{Material examined}

Holotype

PORTUGAL: §̂, Gruta da Alvide, Cascais, Lisbon Peninsula, 26 Dec. 2009 (MZUF). 


\section{Paratypes}

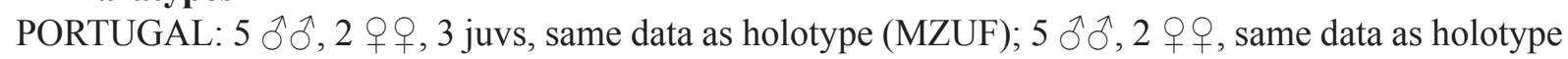
(SR); 5 $\widehat{\partial}, 2$ 우, same data as holotype (ZMUC).

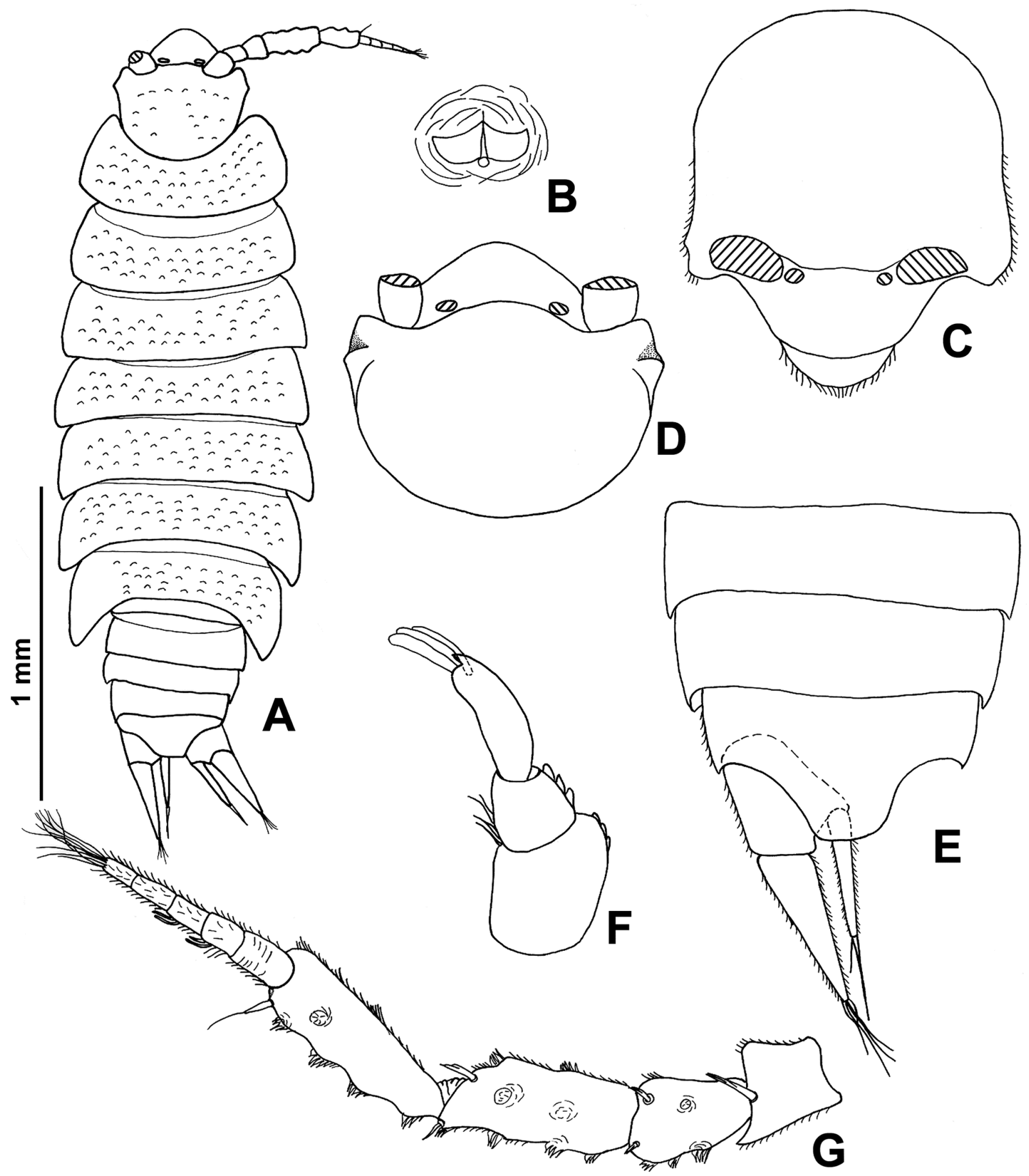

Fig. 13. Troglonethes olissipoensis Reboleira \& Taiti sp. nov. from Gruta de Alvide, Lisbon Peninsula.

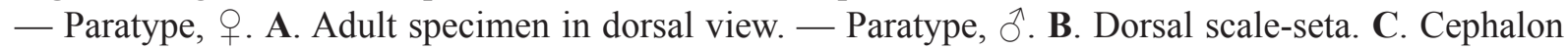
in frontal view. D. Cephalon in dorsal view. E. Pleonites 4, 5, telson and left uropod. F. Antennula. G. Antenna. 


\section{Description}

Maximum size: ô $3.5 \times 0.8 \mathrm{~mm}$; $94.2 \times 1.2 \mathrm{~mm}$. Body colourless and elongated (Fig. 13A). Dorsum of cephalon and pereon granulated; each granule equipped with a triangular scale-seta (Fig. 13B); pleon and telson smooth. Cephalon (Fig. 13C-D) with quadrangular frontal lateral lobes slightly protruding outwards. Eyes absent. Pereonites 1-4 (Fig. 13A) with rounded posterior corners; pereonites 5-7 (Fig. 13A) with epimera pointing backwards. Pleon (Fig. 13A, E) narrower than pereon; pleonites 3-5 with small epimera and very short posterior points. Telson (Fig. 13E) about twice as wide as long, with distal part trapezoidal with concave sides. Antennula (Fig. 13F) with three articles; third article with spine and three long aesthetascs at apex. Antenna (Fig. 13G) with third, fourth and fifth article of peduncle with distinct tubercles bearing scale-setae; fifth article as long as flagellum; flagellum with five articles, with two long aesthetascs on second and third article. Mandibles (Fig. 14A-B) with one penicil on the right and three on the left. Maxillula (Fig. 14C) with inner branch bearing three penicils at apex, inner one distinctly longer than other two; outer branch with 12 teeth and thin, setose stem among outer group of teeth. Maxilla (Fig. 14D) apically bilobed and setose, with outer and inner lobes subequal; inner lobe with several long stout setae along margin. Maxilliped (Fig. 14E) endite triangular, with stout triangular

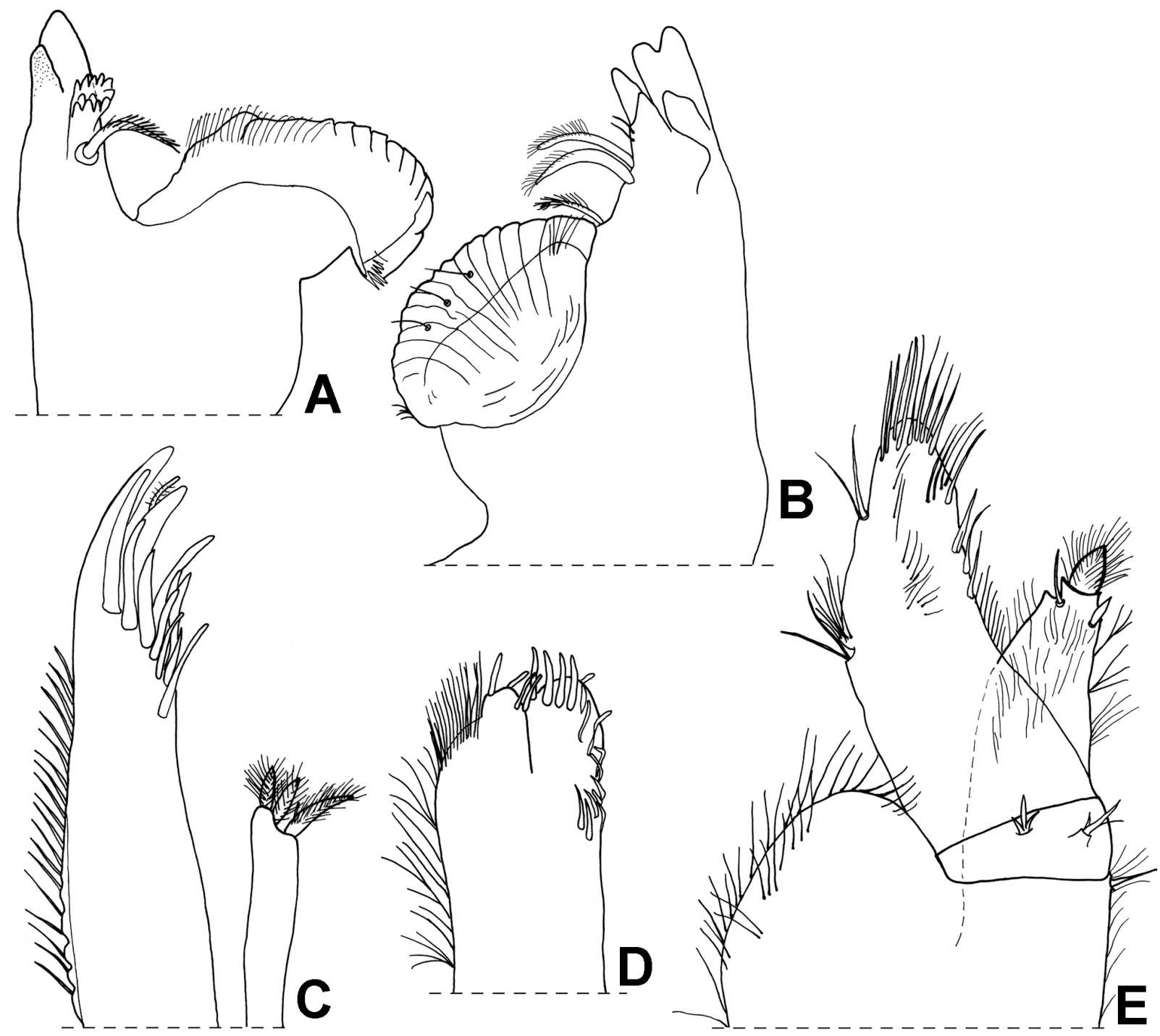

Fig. 14. Troglonethes olissipoensis Reboleira \& Taiti sp. nov. from Gruta de Alvide, Lisbon Peninsula, paratype, ô. A. Right mandible. B. Left mandible. C. Maxillula. D. Maxilla. E. Maxilliped. 
penicil at apex; palp distally rounded, with long setae, basal article with two short, compound setae. Uropod (Fig. 13E) with exopod slightly longer than endopod and more distally inserted; exopod with several long pointed setae and endopod with a long and a short seta at apex.

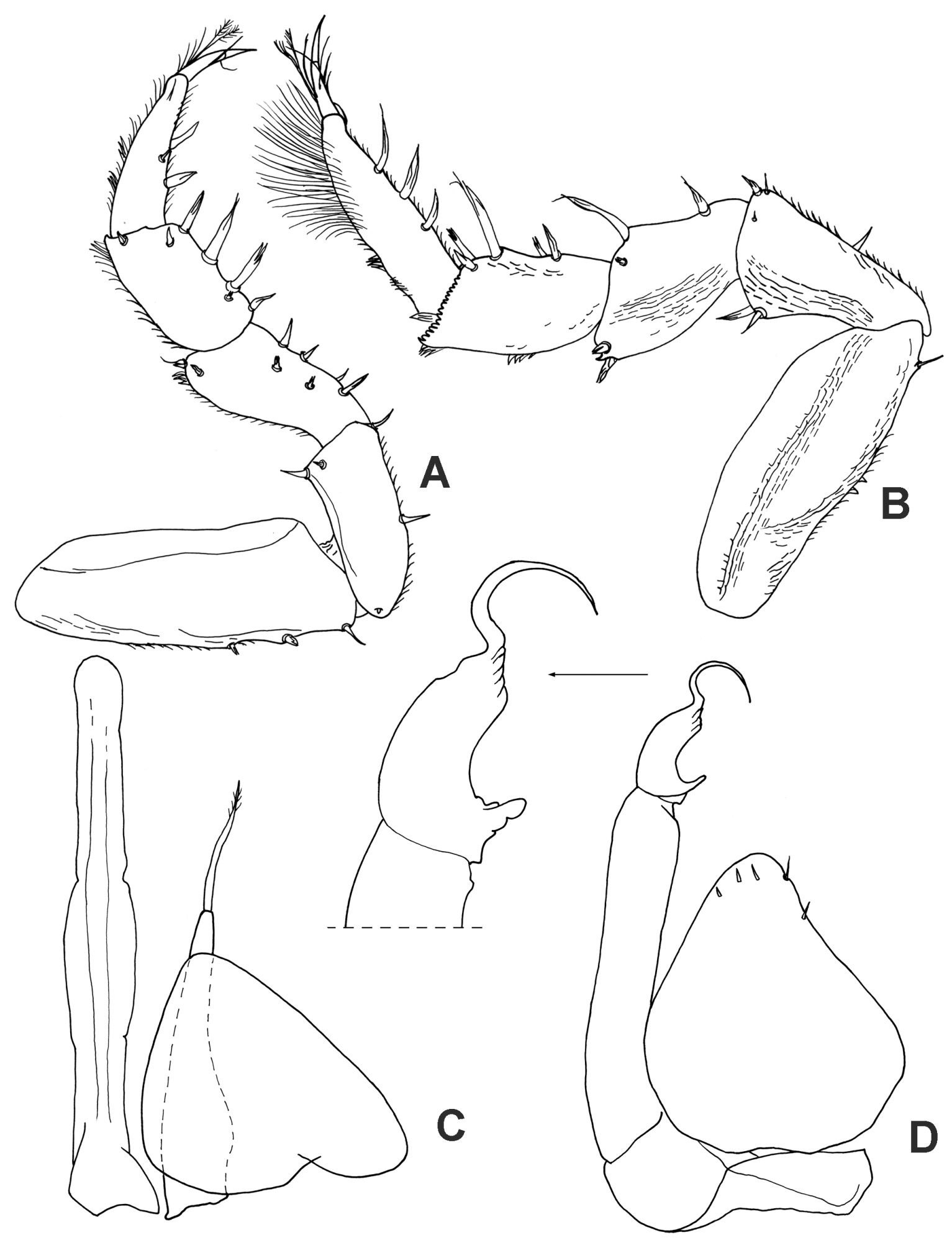

Fig. 15. Troglonethes olissipoensis Reboleira \& Taiti sp. nov. from Gruta de Alvide, Lisbon Peninsula, paratype, ô. A. Pereopod 1. B. Pereopod 7. C. Genital papilla and pleopod 1. D. Pleopod 2. 
MaLE. Pereopod 1 (Fig. 15A) with no particular modifications. Pereopod 7 (Fig. 15B) ischium with straight sternal margin, carpus with row of scales on distal margin, and propodus with long, thin setae on distal half of tergal margin. Genital papilla (Fig. 15C) fusiform, with rounded apex, much longer than pleopod 1. Pleopod 1 (Fig. 15C) exopod triangular, as wide as long, with broadly rounded apex; endopod with basal article elongated, longer than exopod, with sinuous outer margin, distal article flagelliform with setose apex. Pleopod 2 (Fig. 15D) exopod triangular, with broadly rounded apex with few short setae; endopod biarticulated, basal article about three times as long as distal one, with parallel sides, distal article with outer margin bearing hook-like process at base and one at apex.

\section{Remarks}

The genus Troglonethes was erected by Cruz (1989) for the new species T. aurouxi from a cave north of Valencia, Spain. Tabacaru (1993) included the genus in the tribe Speleonethini. The new species from Portugal is included in the genus since it has all the characters listed in the diagnosis. Troglonethes olissipoensis Reboleira \& Taiti sp. nov. differs from T. aurouxi in having an antennal flagellum with five, instead of four, articles, the male pleopod 1 exopod shorter than the basal article of the endopod, and the male pleopod 2 endopod with a basal hook-like process on the outer margin of the distal article.

\section{Ecological notes}

This species was only found in Gruta de Alvide, located in an overurbanized area, with part of the cave ceiling used as the base of a residential building. The specimens were collected in the deepest parts of the cave, the so-called third level. It is the second troglobiotic species from karst caves in the Lisbon Peninsula, after the record of the bristletail Coletinia sp. in Gruta de Colaride (Reboleira et al. 2012a). Unidentified springtails and blaniulid millipedes were also collected.

\section{Troglonethes arrabidaensis Reboleira \& Taiti sp. nov. urn:1sid:zoobank.org:act:78A12550-F7CA-4892-9E90-7F85446423D3}

Figs $16 \mathrm{~A}-\mathrm{G}, 17 \mathrm{~A}-\mathrm{D}$

\section{Diagnosis}

A species of Troglonethes characterised by the antenna having three flagellar articles, the male pereopod 7 carpus enlarged in the basal part, the pleopod 1 exopod triangular, as wide as long, and the male pleopod 2 endopod with the distal article bearing an apical hook-like process.

\section{Etymology}

The new species is named after the type locality, the Arrábida karst massif.

\section{Material examined}

Holotype

PORTUGAL: §ึ, Gruta do Frade, Arrábida Massif, 16 Aug. 2013 (MZUF).

\section{Paratypes}

PORTUGAL: $3 \precsim \widehat{\jmath}, 13$ $q$, same data as holotype (MZUF, SR and ZMUC).

\section{Description}

Maximum size: 0 and $\uparrow 2.7 \times 0.8 \mathrm{~mm}$. Body colourless and elongated (Fig. 16A). Dorsum of cephalon and pereonites with two rows and one row of large granules, respectively; each granule with a scale-seta (Fig. 16B); pleon and telson smooth. Cephalon (Fig. 16C-D) with short, quadrangular frontal lateral lobes. Eyes absent. Pereonites 1-3 with rounded posterior corners; pereonites 4-7 with epimera pointing backwards (Fig. 16A). Pleon (Fig. 16A, E) slightly narrower than pereon; pleonites 3-5 with small 
epimera and very short posterior points. Telson (Fig. 16E) about twice as wide as long, with distal part trapezoidal, with concave sides and broadly rounded apex. Antennula (Fig. 16F) with three articles; third article with three long aesthetascs at apex. Antenna (Fig. 16G) with fourth and fifth article of peduncle with distinct tubercles bearing scale-setae; fifth article slightly shorter than flagellum; flagellum with

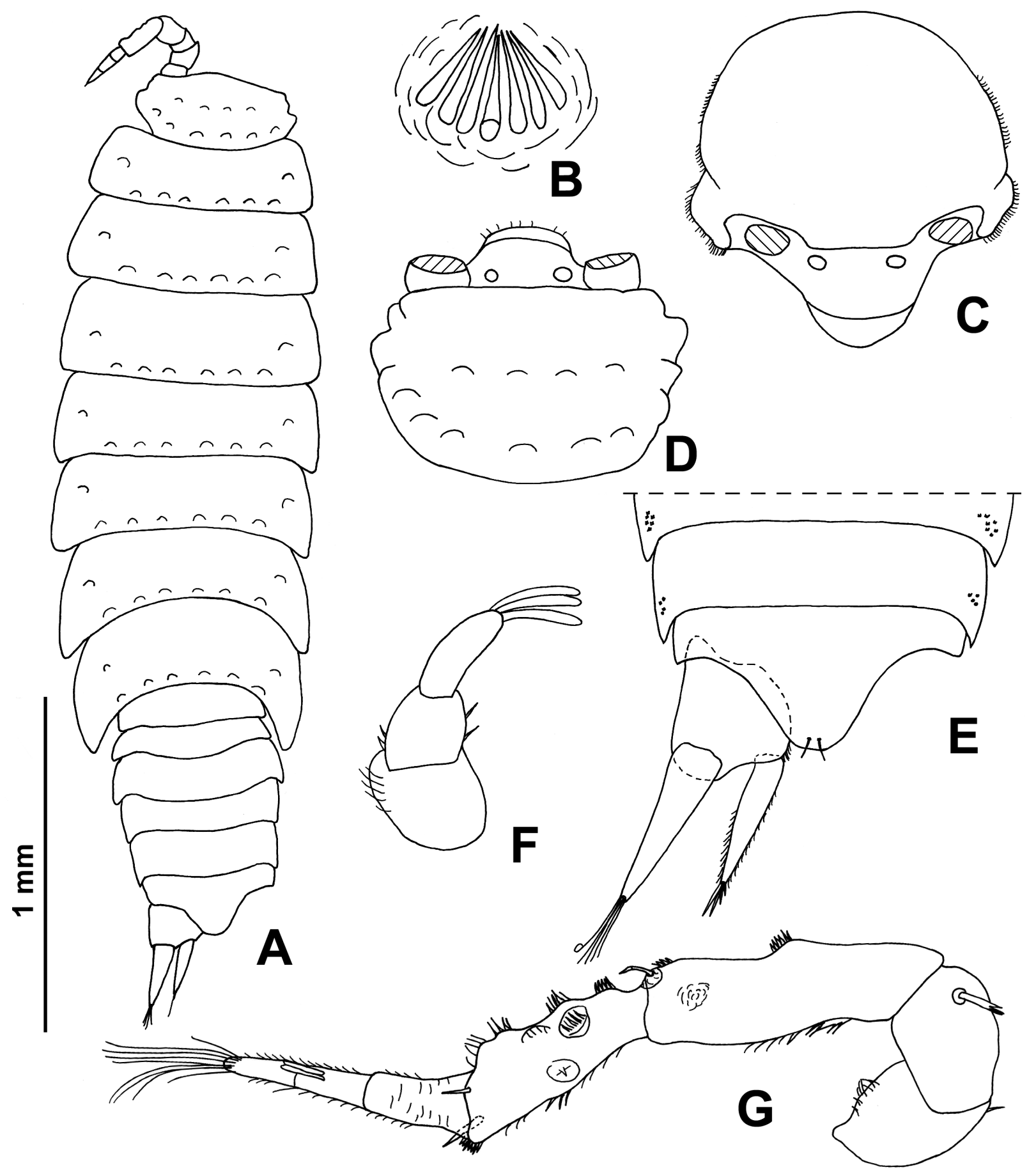

Fig. 16. Troglonethes arrabidaensis Reboleira \& Taiti sp. nov. from Gruta do Frade, Arrábida. Paratype, o. A. Adult specimen in dorsal view. B. Dorsal scale-seta. C. Cephalon in frontal view. D. Cephalon in dorsal view. E. Pleonites 4, 5, telson and left uropod. - Paratype, ô. F. Antennula. G. Antenna. 
three articles, with two long aesthetascs on second article. Buccal pieces as in previous species. Uropod (Fig. 16E) with exopod slightly longer than endopod, exopod and endopod inserted at same level.

MALE. Pereopod 1 (Fig. 17A) with no particular modifications. Pereopod 7 (Fig. 17B) ischium with straight sternal margin, carpus enlarged in basal part. Genital papilla (Fig. 17C) fusiform, with rounded apex, much longer than pleopod 1. Pleopod 1 (Fig. 17C) exopod triangular, as wide as long, with broadly rounded apex; endopod with basal article elongated, shorter than exopod, with sinuous outer margin, distal article flagelliform. Pleopod 2 (Fig. 17D) exopod triangular, with broadly rounded apex with few short setae; endopod biarticulated, basal article more than twice as long as distal one, with parallel sides, distal article with hook-like process at apex.

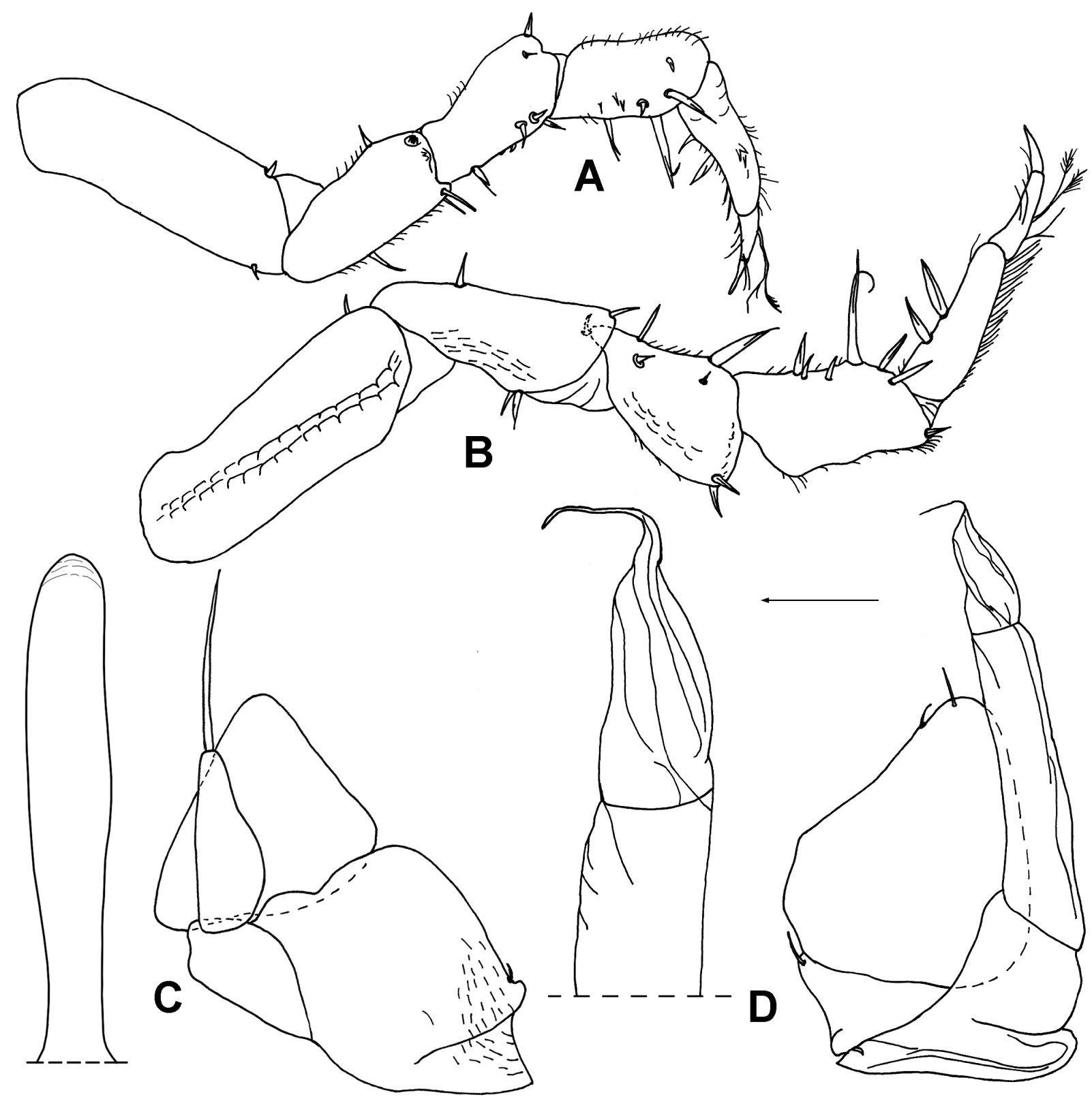

Fig. 17. Troglonethes arrabidaensis Reboleira \& Taiti sp. nov. from Gruta do Frade, Arrábida, paratype, Õ. A. Pereopod 1. B. Pereopod 7. C. Genital papilla and pleopod 1. D. Pleopod 2. 


\section{Remarks}

The new species is very similar to Troglonethes aurouxi in the dorsal granulation and shape of the male pleopod 2. It differs in having the antennal flagellum with three, instead of four, articles, and a wider male pleopod 1 exopod. It is readily distinguishable from T. olissipoensis Reboleira \& Taiti sp. nov. in the larger and less numerous dorsal granules, the enlarged basal part of the male pereopod 7 carpus, the male pleopod 1 endopod with the basal article shorter than the exopod, and the distal article of the male pleopod 2 endopod lacking the hook-like process at the base.

\section{Ecological notes}

This species was only found in the Gruta do Frade in the Arrábida Massif. The cave entrance is by the seashore and there are several anchialine lakes inside, influenced by the sea tides. It is the first record of troglobiotic terrestrial isopods in Arrábida.

Genus Miktoniscus Kesselyák, 1930

Miktoniscus longispina Reboleira \& Taiti sp. nov. urn:1sid:zoobank.org:act:6B9A5E8B-53F8-408D-B3BA-8E10BCE20717

Figs 18A-F, 19A-E, 20A-D

\section{Diagnosis}

A species of Miktoniscus characterised by a depigmented body, the male pereopod 7 having a long and stout seta on the distal corner of the ischium, and a triangular male pleopod 1 exopod.

\section{Etymology}

From Latin longus $=$ long + spina $=$ spine. The name of the new species refers to the long, thick seta on the distal part of the male pereopod 7.

\section{Material examined}

\section{Holotype}

PORTUGAL: §̊, Gruta dos Bolhos, Cesaredas Plateau, 26 Dec. 2010 (MZUF).

\section{Paratype}

PORTUGAL: 1 , , same locality as holotype, Feb. 2009 (MZUF).

\section{Additional material}

PORTUGAL: 1 ô, 2 q , Gruta da Cerâmica, Sicó Massif, 10 Jun. 2011 (MZUF); 2 đ̂̉, 3 q $q$, same locality, 2 Mar. 2013 (SR); 1 §, 1 ㅇ, Algar da Ervilha, Sicó, 30 Mar. 2014 (ZMUC).

\section{Description}

Maximum size: $\delta$ and $\uparrow 3.5 \times 1.0 \mathrm{~mm}$. Body depigmented, elongated (Fig. 18A). Dorsum of cephalon and pereon distinctly granulated, each granule bearing a scale-seta on top (Fig. 18B). Cephalon (Fig. 18C) with no frontal lobes. Eye consisting of single black ocellus (lacking in specimens from Gruta da Cerâmica and Algar da Ervilha). Pereonites 1-4 with rounded posterior corners; pereonites 5-7 with epimera pointing backwards (Fig. 18A). Pleon (Fig. 18A, D) slightly narrower than pereon; pleonites 3-5 with reduced epimera and very short posterior points. Telson (Fig. 18D) about twice as wide as long, with rectangular basal part and trapezoidal distal part, with almost straight sides. Antennula (Fig. 18E) with three articles; third article with short spine and four long aesthetascs at apex (five in specimens from Gruta da Cerâmica and Algar da Ervilha). Antenna (Fig. 18F) with fifth article of peduncle slightly longer than flagellum; flagellum with four articles, with one aesthetasc on second article and two 
aesthetascs on third article (two and four, respectively, in specimens from Gruta da Cerâmica and Algar da Ervilha). Mandibles (Fig. 19A-B) with one penicil on the right and two on the left; molar process without penicils. Maxillula (Fig. 19C) with inner branch bearing three penicils at apex, diminishing in size from proximal to distal; outer branch with nine teeth and thin stem. Maxilla (Fig. 19D) apically bilobed, outer lobe smaller and shorter than inner one; inner lobe with line of several long, stout setae near apical and inner margins. Maxilliped (Fig. 19E) endite triangular, with stout triangular penicil at

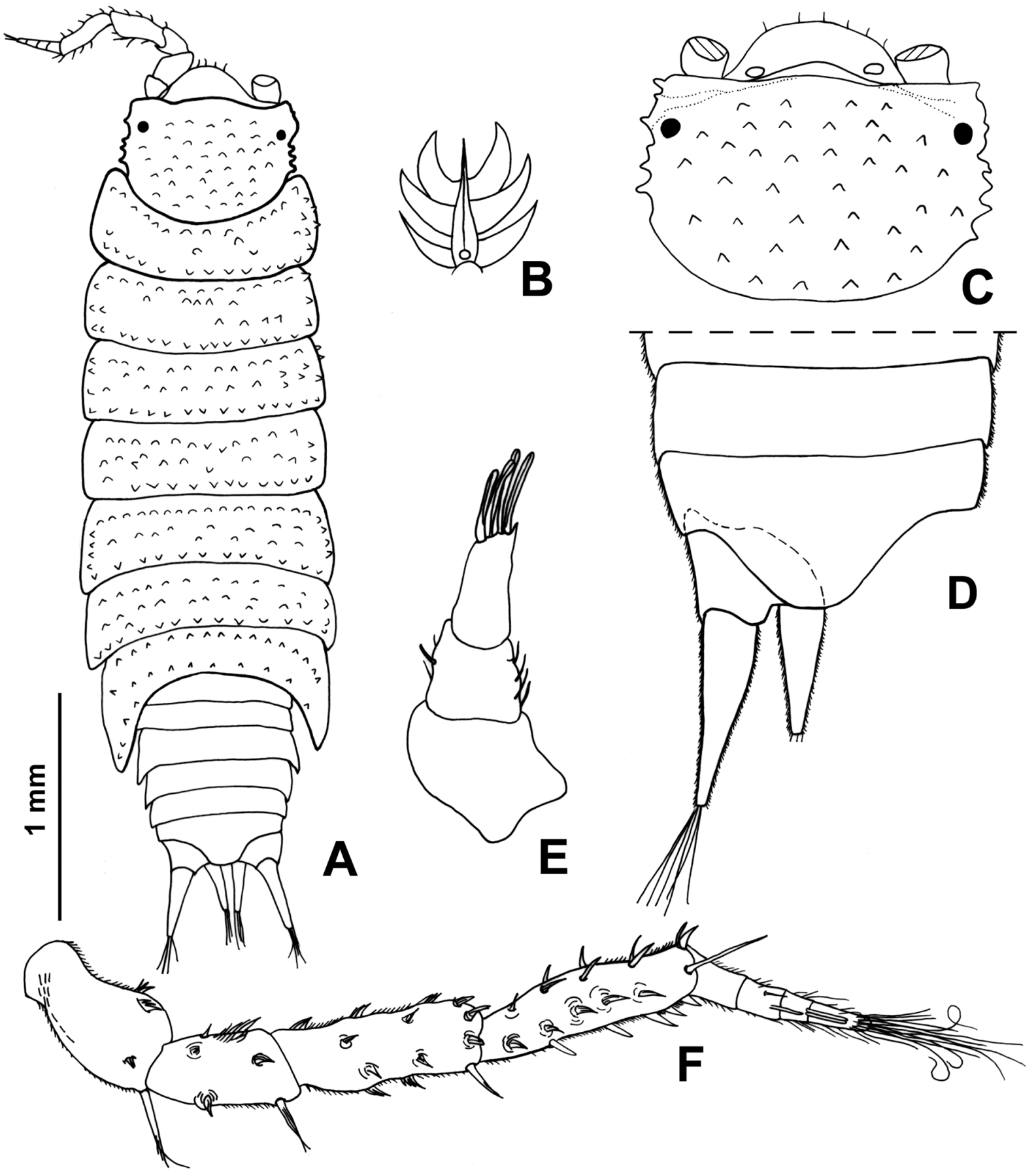

Fig. 18. Miktoniscus longispina Reboleira \& Taiti sp. nov. from Gruta dos Bolhos, Cesaredas Plateau. - Paratype,, . A. Specimen in dorsal view. - Paratype, $\overbrace{}^{\lambda}$. B. Dorsal scale-seta. C. Cephalon in dorsal view. D. Pleonite 5, telson and left uropod. E. Antennula. F. Antenna. 
apex; palp elongated, with long setae on margin of apical part, and basal article with two short, simple setae. Uropod (Fig. 18E) with exopod distinctly longer than endopod and more distally inserted.
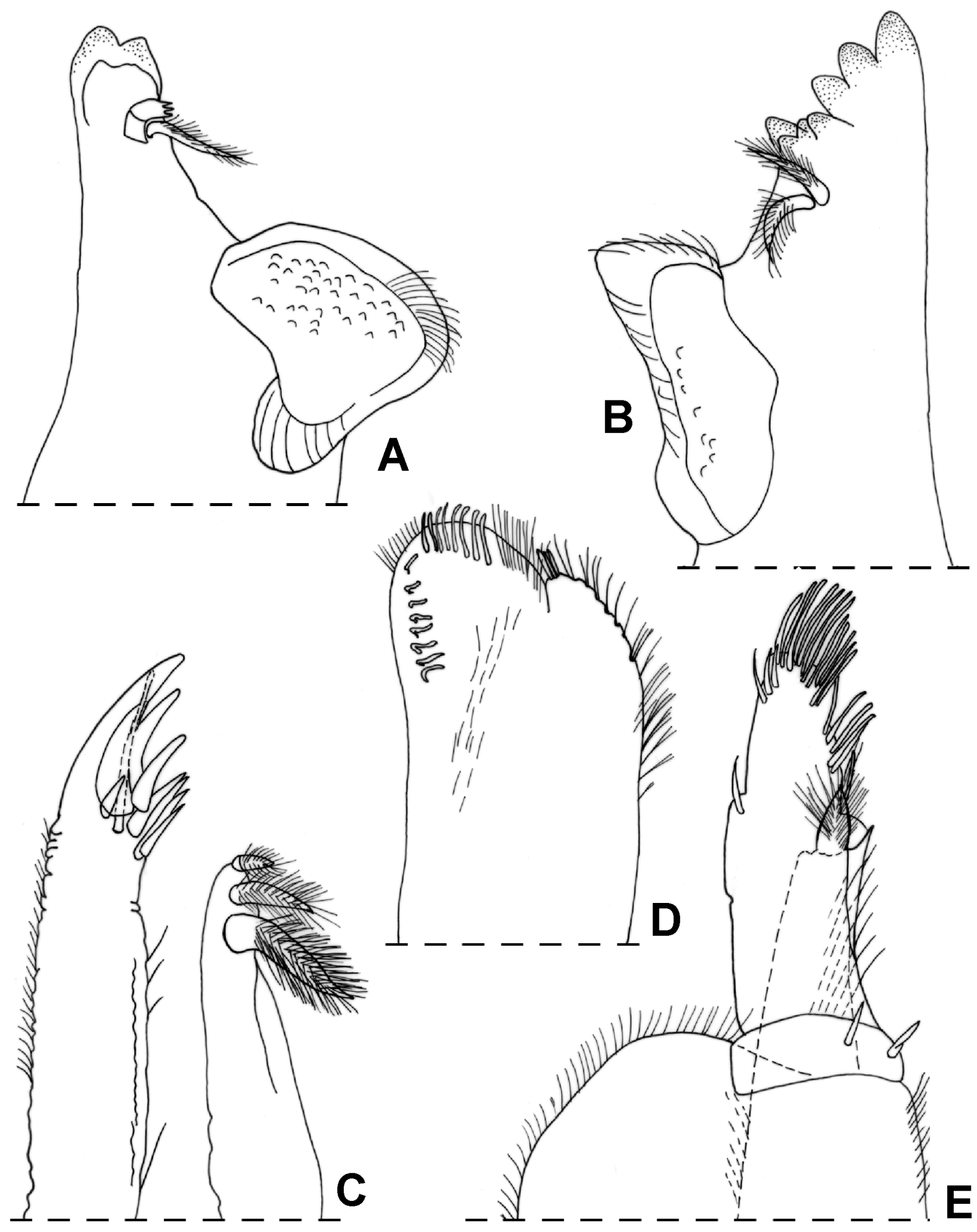
Male. Pereopod 1 (Fig. 20A) with no distinct sexual modifications. Pereopod 7 (Fig. 20B) ischium triangular, with strong seta, as long as merus, at corner between distal and sternal margin; sternal margin of merus sinuous, with one recurved seta and one pointed seta in the middle; carpus with distal part enlarged, with some strong setae on sternal margin. Pleopod 1 (Fig. 20C) exopod triangular, about

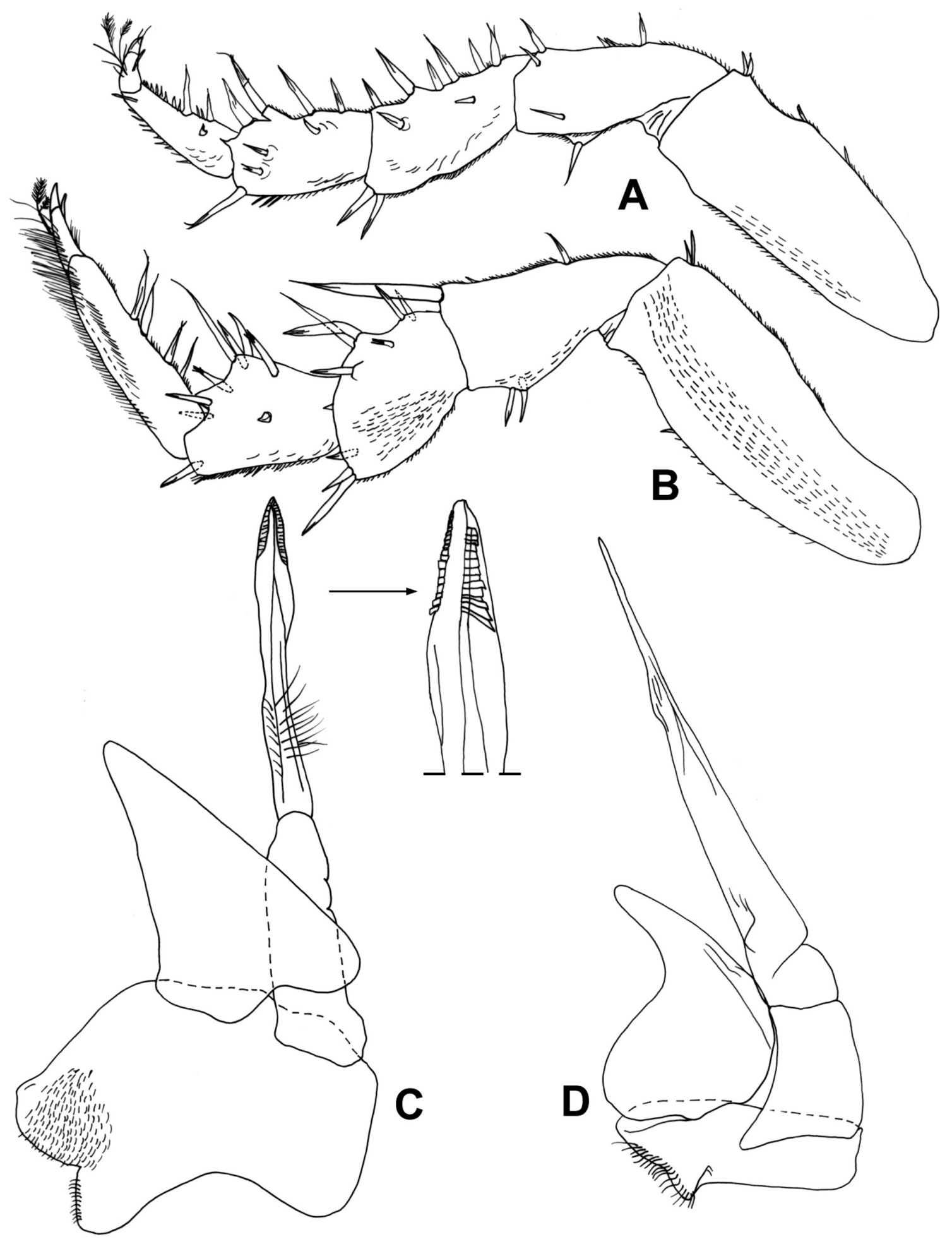

Fig. 20. Miktoniscus longispina Reboleira \& Taiti sp. nov. from Gruta dos Bolhos, Cesaredas Plateau, paratype, §. A. Pereopod 1. B. Pereopod 7. C. Pleopod 1. D. Pleopod 2. 
twice as long as wide; endopod with basal article distinctly shorter than distal article, which is slightly enlarged subapicaly, with triangular and crenulated apical part. Pleopod 2 (Fig. 20D) exopod triangular, with distinctly concave outer margin; endopod biarticulated, distal article fusiform, elongated, about four times as long as first article.

\section{Remarks}

At present, the genus Miktoniscus includes 15 species distributed in the Americas and Western Europe, including the Atlantic islands (Schmalfuss 2003). The new species is readily distinguishable from all species in the genus by the presence of a strong and long seta at the distal corner of the male pereopod 7 ischium. In continental Portugal and northwestern Spain only one species was previously known, Miktoniscis bisetosus Vandel, 1946, from which M. longispina Reboleira \& Taiti sp. nov. also differs in lacking a recurved seta on the male pereopod 7 carpus and in having the male pleopod 1 exopod with an acute, rather than broadly rounded, apex. The new species occurs in two distinct massifs of central Portugal, on the west border of Cesaredas Plateau near the Atlantic coast, and in Gruta da Cerâmica and Algar da Ervilha in the centre of Sicó Massif. Some differences are present in the specimens from Sicó compared with the type specimens from Cesaredas, i.e., the lack of visible eyes and the different number of aesthetascs on the antennula and antennal flagellum. For this reason, we have not designated the additional material as paratypes. However, since the male characters are the same in all these populations, we consider them as belonging to the same species.

Genus Haplophthalmus Schöbl, 1860

Haplophthalmus siculus Dollfus, 1896

Haplophthalmus siculus Dollfus, 1896: 5, fig. 3.

Haplophthalmus siculus - Vandel 1946: 192, figs 36-41.

\section{Records}

Cova da Adiça, Moura; Gruta do Algar, Mexilhoeirinha, Lagoa (Vandel 1946).

\section{Distribution}

Portugal, Spain, southern Italy and Sicily.

Genus Moserius Strouhal, 1940

Moserius inexpectatus Reboleira \& Taiti sp. nov. urn:lsid:zoobank.org:act:18B5B016-F7A6-4047-A2CB-28B4394797CF

Figs $21 \mathrm{~A}-\mathrm{E}, 22 \mathrm{~A}-\mathrm{C}$

\section{Diagnosis}

A species of Moserius characterised by the male pereopod 7 carpus having a distal lobe on the sternal margin, and the pleopod 1 exopod having a truncate and sinuous distal point.

\section{Etymology}

From Latin inexpectatus = unexpected. The name refers to the location, which is far from the previously known distribution range of the genus.

\section{Material examined}

Holotype

PORTUGAL: ${ }^{\curvearrowright}$, Gruta do Almonda (= Gruta do Olho da Fonte), Estremenho Massif, 24 Aug. 2013 (MZUF). 


\section{Description}

Size: $1.5 \times 0.6 \mathrm{~mm}$. Body colourless, ovoidal, outline not interrupted between pereon and pleon; pereon tergites very convex, with epimera obliquely directed outwards (Fig. 21A). Dorsum bearing ribs and tubercles (Fig. 21A): cephalon with large central tubercle with $3+3$ rounded tips, and $3+3$ tubercles near rear margin, the two external ones fused at base; pereonites 2-6 with $3+3$ longitudinal ribs as long as tergites; pereonite 7 with $2+2$ ribs and small tubercle per side between two ribs; pleonite 3 with 2 large paramedian tubercles; pleonites 4 and 5 and telson with 2 small paramedian tubercles. Cephalon(Fig. 21B) with short, quadrangular frontal lateral lobes, directed outwards and not protruding compared with median lobe. Eyes absent. Pereonites with rounded posterior corners; epimera 4-7 slightly pointing backwards

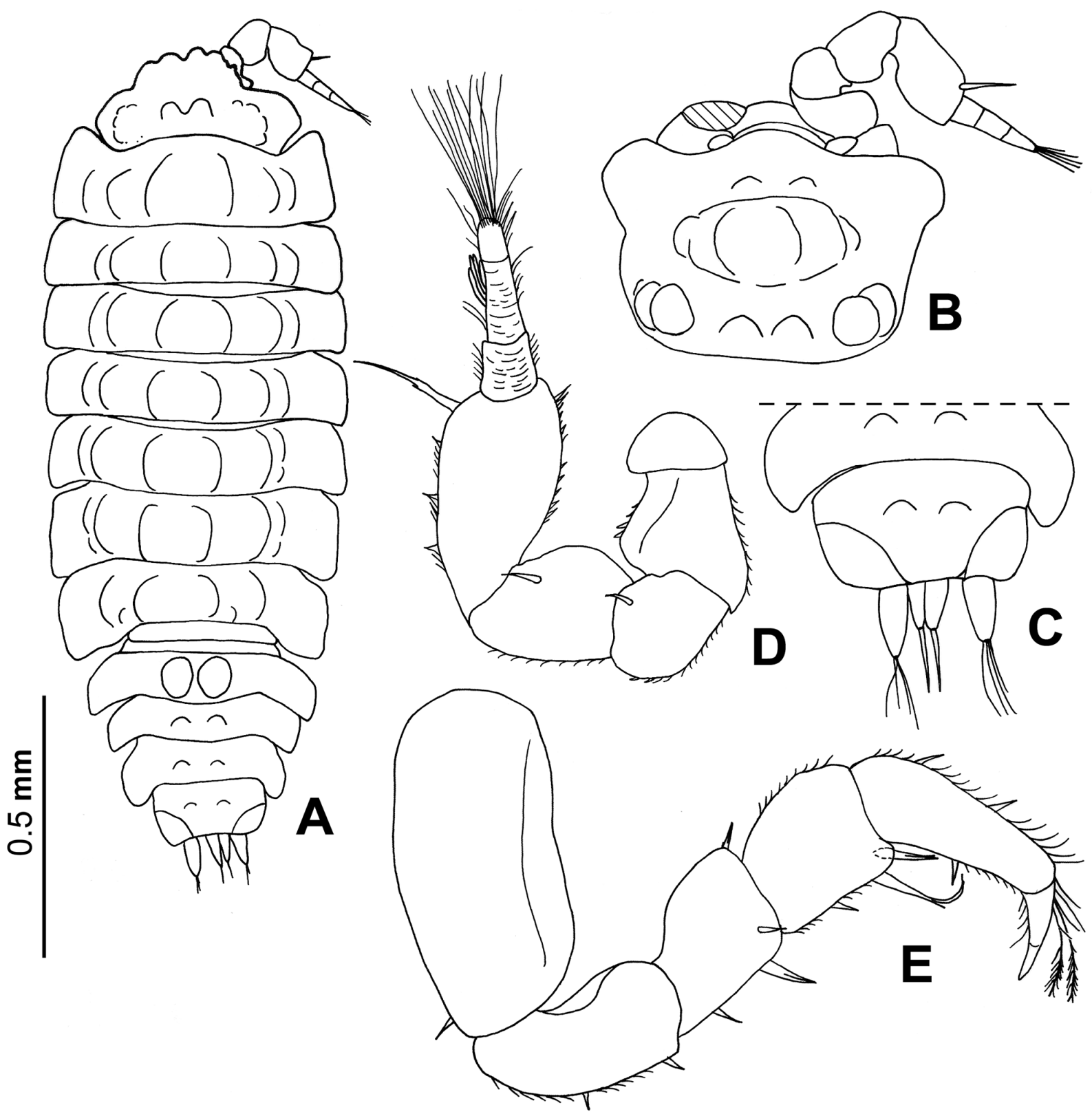

Fig. 21. Moserius inexpectatus Reboleira \& Taiti sp. nov. from Gruta do Almonda, Estremenho, paratype, $\widehat{\jmath}$. A. Specimen in dorsal view. B. Cephalon in dorsal view. C. Pleonite 5, telson and uropod. D. Antenna. E. Pereopod 1. 
(Fig. 21A). Pleonites 3-5 (Fig. 21A, C) with large epimera directed backwards. Telson (Fig. 21C) about twice as wide as long, with distal part trapezoidal, with concave sides and truncate apex. Antenna (Fig. 21D) with thickset articles of peduncle; flagellum with three articles, with 3-4 long aesthetascs on second article. Uropod (Fig. 21C) with flattened protopod; exopod slightly longer than endopod, with tuft of four apical setae; endopod with single apical seta. Pereopod 1 (Fig. 21E) with no particular modifications. Pereopod 7 (Fig. 22A-B) ischium with slightly convex sternal margin, carpus with large distal lobe on sternal margin. Pleopod 1 (Fig. 22C) exopod quadrangular, with truncate and sinuous distal point, sinuous outer margin and straight medial margin.

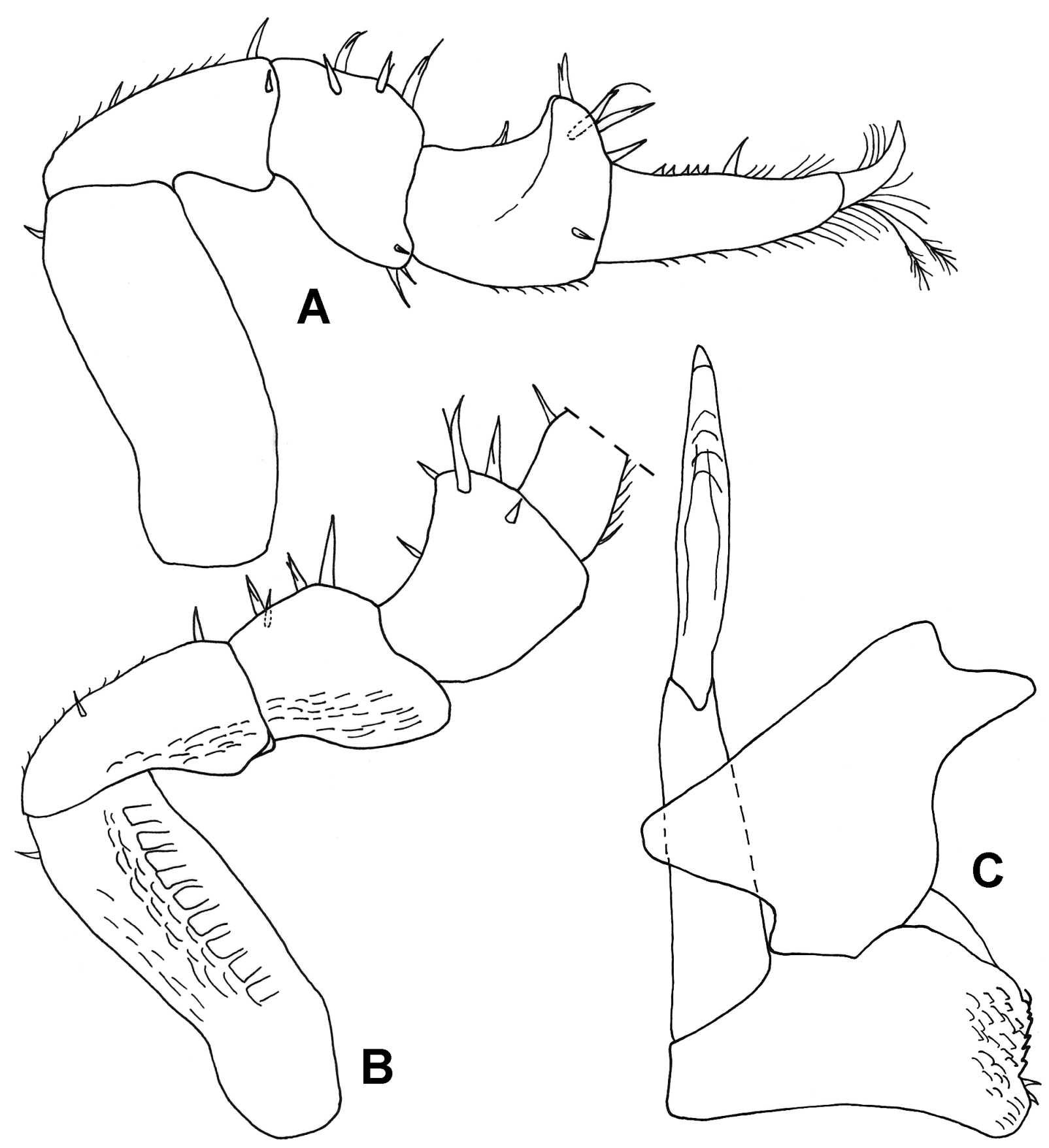

Fig. 22. Moserius inexpectatus Reboleira \& Taiti sp. nov. from Gruta do Almonda, Estremenho, EstremozCano Massif, paratype, ô. A. Pereopod 7, caudal view. B. Pereopod 7, rostral view. C. Pleopod 1. 


\section{Remarks}

This new blind species belongs to the subfamily Haplophthalminae and is included in Moserius since it shows the tergal ornamentation typical of the genus, i.e., $3+3$ ribs on the pereonites and two large tubercles on pleonite 3 . The genus Moserius was previously known only for two species: M. percoi Strouhal, 1940, originally described from the cave Belinca Jama, Slovenia, and later recorded from Ligurian and Tuscan caves (Strouhal 1940; Brian 1963; Taiti \& Ferrara 1995), and M. elbanus Taiti \& Ferrara, 1995, from a small cave on Elba Island, Tuscany, Italy. The new species is readily distinguished from the other two members of the genus by the peculiar shape of the male pleopod 1 exopod, with a truncate and sinuous, rather than triangular, distal point. The location of M. inexpectatus (Portugal) is very far from those of the other two species (northern Italy and Slovenia), but it is quite probable that other species are present in the countries encompassing the northwestern Mediterranean.

\section{Ecological notes}

This species occurs in the Gruta do Almonda, the largest Portuguese cave, with at least $10 \mathrm{~km}$ of mapped subterranean galleries. It shares habitat with other troglobiotic species, namely the spider Nesticus lusitanicus Fage, 1931, the woodlouse Trichoniscoides meridionalis, and the beetle Trechus lunai Reboleira \& Serrano, 2009 (Reboleira et al. 2009).

Family Styloniscidae Vandel, 1952

Genus Cordioniscus Gräve, 1914

Cordioniscus lusitanicus Reboleira \& Taiti sp. nov. urn:1sid:zoobank.org:act:B1F2D756-D90F-43BF-9F42-4F8EAE6C79F0

Figs $23 \mathrm{~A}-\mathrm{G}, 24 \mathrm{~A}-\mathrm{E}, 25 \mathrm{~A}-\mathrm{E}$

\section{Diagnosis}

A blind species of Cordioniscus characterised by a colourless body, the male pereopod 7 ischium having a rounded hyaline basal lobe, the triangular male pleopod 1 exopod, as long as the endopod, and the complex apical part of the male pleopod 2 endopod.

\section{Etymology}

From Latin lusitanicus $=$ Portuguese. The name refers to the country where the specimens were collected.

\section{Material examined}

\section{Holotype}

PORTUGAL: O̊, Algar de Santo António, Estremoz-Cano Massif, 30 Mar. 2009 (MZUF).

\section{Paratypes}

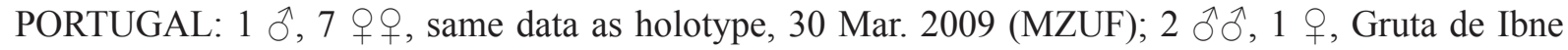

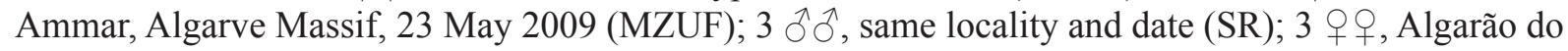
Remexido, Algarve Massif, 5 Sep. 2009 (SR); 1 §ิ, same locality, 30 Jan. 2009 (MZUF); 2 우, same locality, 29 Dec. 2009 (SR); 1 ○ juv., 2 우, Gruta da Senhora, Algarve Massif, 3 Jul. 2011 (ZMUC); 1 गे, same locality, 18 May 2013 (SR).

\section{Description}

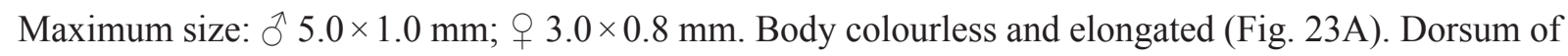
cephalon and pereon finely granulated and equipped with triangular scale-setae (Fig. 23B); pleon and telson smooth. Cephalon (Fig. 23C-D) with short, rounded frontal lateral lobes. Eyes absent. Pereonites 
1-3 with rounded posterior corners; pereonites 4-7 with epimera pointing backwards (Fig. 23A). Pleon (Fig. 23A, E) narrower than pereon; pleonites 3-5 with epimera reduced and no posterior points.

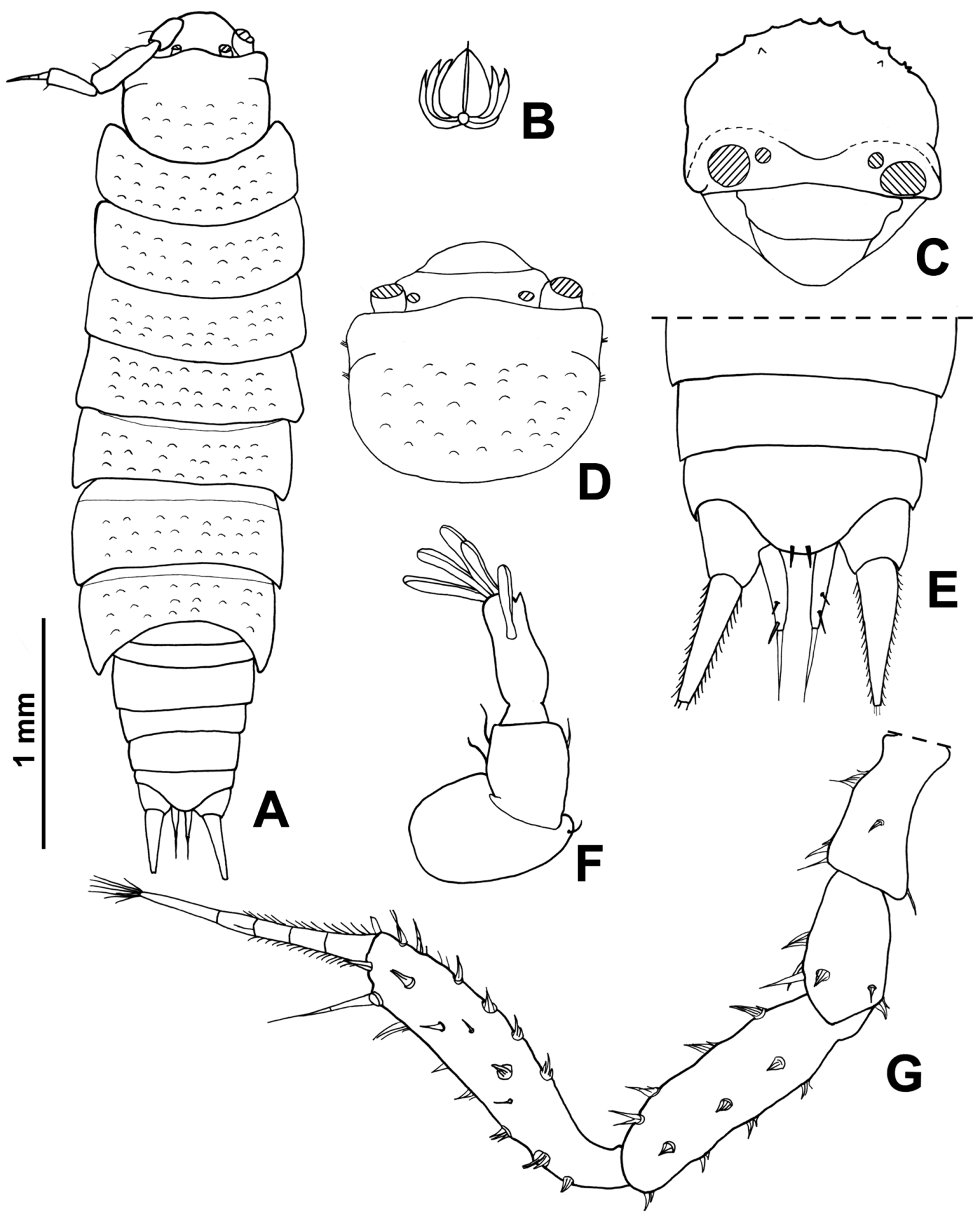

Fig. 23. Cordioniscus lusitanicus Reboleira \& Taiti sp. nov. from Algar de Santo António, EstremozCano. - Paratype, ๆ. A. Adult specimen in dorsal view. - Paratype, O. B. Dorsal scale-seta. C. Cephalon in frontal view. D. Cephalon in dorsal view. E. Pleonites 4, 5, telson and uropods. F. Antennula. G. Antenna. 
Telson (Fig. 23E) about twice as wide as long, distal part with concave sides and broadly rounded apex. Antennula (Fig. 23F) with third article longer than first and second articles, with small triangular posterior point, and with one subapical and four apical, long aesthetascs. Antenna (Fig. 23G) with articles of peduncle bearing scale-setae; fifth article distinctly longer than flagellum; flagellum with four articles, with very long apical organ. Right mandible (Fig. 24A) with one penicil between lacinia mobilis and molar process, which bears long penicil; left mandible (Fig. 24A) with two penicils. Maxillula (Fig. 24C) inner branch bearing two thickset penicils at apex and long subapical penicil; outer branch

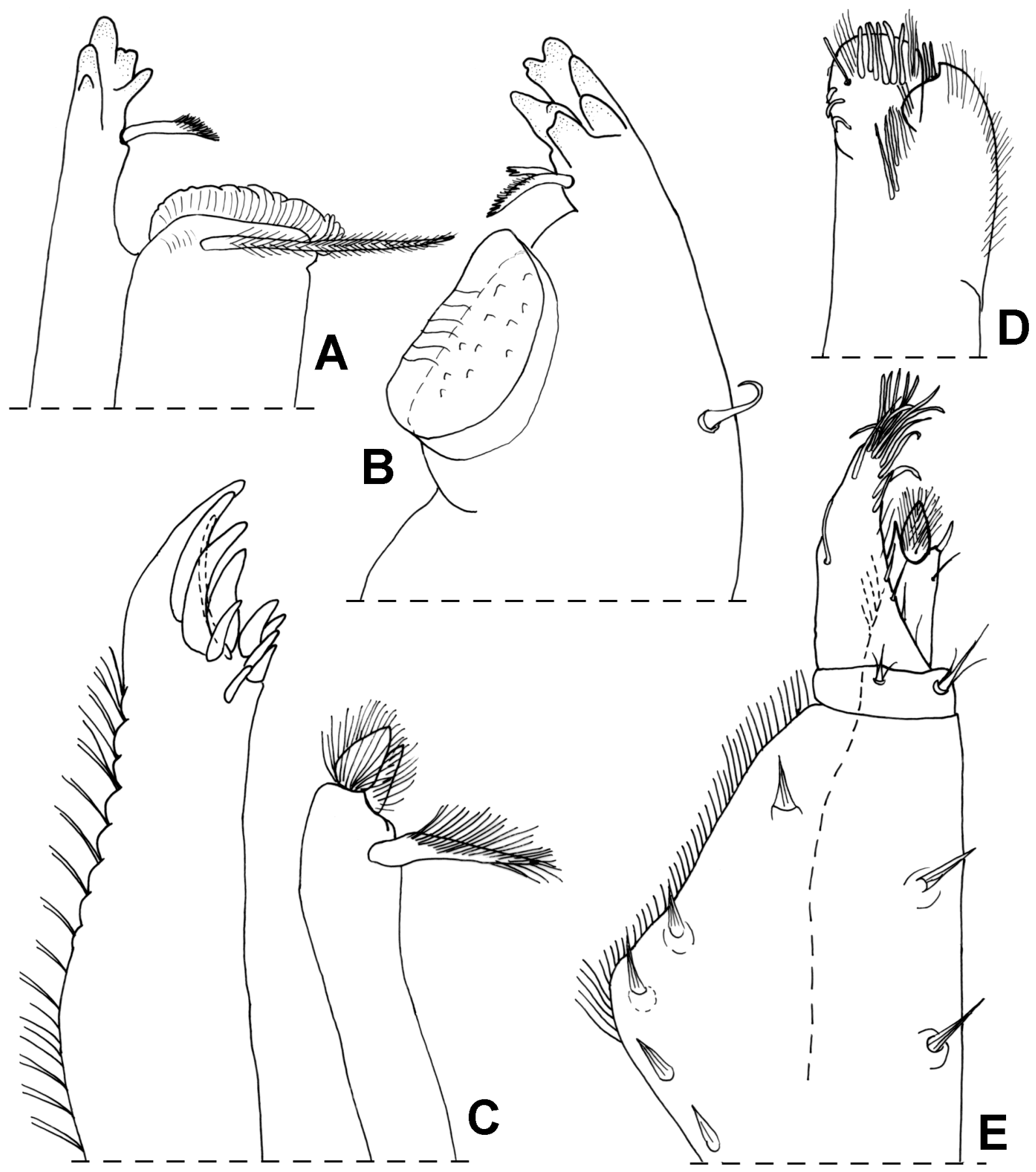

Fig. 24. Cordioniscus lusitanicus Reboleira \& Taiti sp. nov. from Algar de Santo António, EstremozCano, paratype, +. A. Right mandible. B. Left mandible. C. Maxillula. D. Maxilla. E. Maxilliped. 
with 10 teeth and thin, setose stem among outer group of teeth. Maxilla (Fig. 24D) apically bilobed and setose, with outer and inner lobes subequal; inner lobe with several long, stout setae along margin. Maxilliped (Fig. 24E) basis enlarged in middle; endite triangular, with stout triangular penicil at apex; palp distally rounded, with long setae at apex, and basal article with two short compound setae. Uropod (Fig. 23E) with exopod distinctly longer than endopod, endopod inserted proximally to exopod.

MaLE. Pereopod 1 (Fig. 25A) with no particular modifications. Pereopod 7 (Fig. 25B) ischium with slightly convex sternal margin and bearing rounded hyaline lobe at base. Genital papilla (Fig. 25C) lanceolate with pointed apex, shorter than pleopod 1. Pleopod 1 (Fig. 25D) exopod triangular, as long as endopod; endopod with short triangular basal article and flagelliform distal article. Pleopod 2 (Fig. 25E)

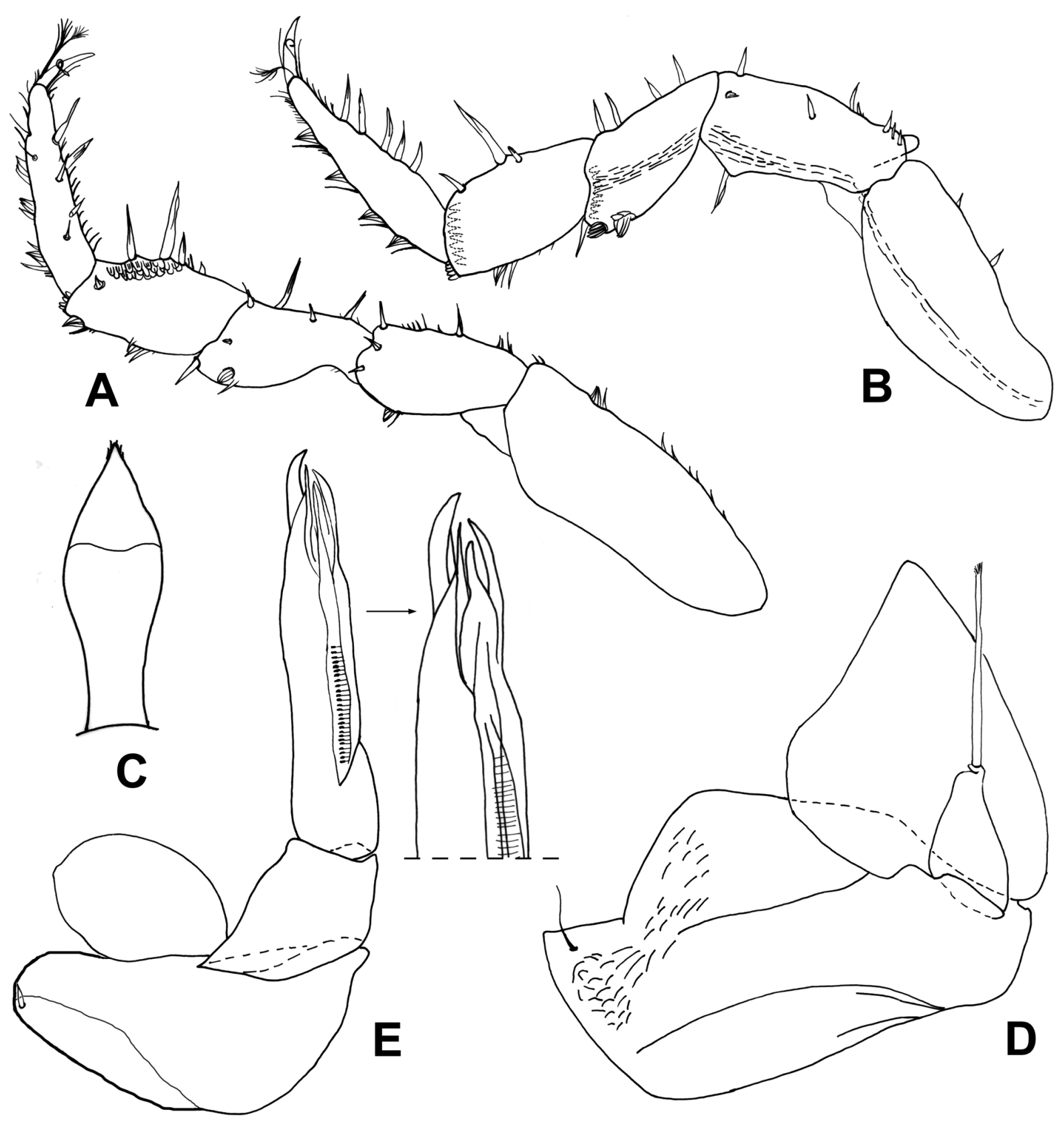

Fig. 25. Cordioniscus lusitanicus Reboleira \& Taiti sp. nov. from Algar de Santo António, EstremozCano, paratype, ô. A. Pereopod 1. B. Pereopod 7. C. Genital papilla. D. Pleopod 1. E. Pleopod 2. 
exopod small, ovoidal; endopod biarticulated, distal article thickset, about three times as long as basal article, with parallel sides and complex apical part.

\section{Remarks}

At present the genus Cordioniscus includes with certainty 14 species (Andreev 2002; Schmalfuss 2003), mainly distributed in caves of Mediterranean countries. For a definition of the genus see Schmalfuss \& Erhard (1998). Species of Cordioniscus are mainly distinguishable by the shape of the male pleopod 2 endopod. In the Iberian Peninsula, only Cordioniscus stebbingi (Patience, 1907) was previously known from some caves in Valencia and Castellón provinces, Spain (Vandel 1952b). The new species differs from C. stebbingi in the lower number of aesthetascs on the antennula (5 vs 8), the presence of a hyaline lobe on the male pereopod 7 ischium, and the thickset and complex, rather than tapering, distal part of the male pleopod 2 endopod. In the presence of a lobe at the base of the male pereopod 7 ischium, C. lusitanus Reboleira \& Taiti sp. nov. is similar to C. bulgaricus Andreev, 1986 from Bulgaria and C. andreevi Schmalfuss \& Erhard, 1998, C. beroni Vandel, 1968, C. graecus Vandel, 1959 and C. kithnosi Andreev, 1986 from Greece (Vandel 1959, 1968; Andreev 1986a, 1986b; Schmalfuss \& Erhard 1998). It differs from all these species in the different structure of the male pleopod 2 endopod.

\section{Ecological notes}

This species was collected in two isolated karst areas, Alentejo and Algarve. These two areas are more than $200 \mathrm{~km}$ apart and are separated by the extended dry, flat areas of Alentejo Province. In the Algarve Massif this species is frequent in caves. In the northern locality, Algar de Santo António in Alentejo, the specimens were collected in deep layers of soil at the bottom of the first pit $(-20 \mathrm{~m})$, where it cohabits with the troglobiotic millipede Sireuma nobile Reboleira \& Enghoff, 2014 (Reboleira \& Enghoff 2014b).

Family Philosciidae Kinahan, 1857

Genus Anaphiloscia Racovitza, 1907

Anaphiloscia sicula Arcangeli, 1934

Anaphiloscia sicula Arcangeli, 1934: 152, figs 1-19.

Anaphiloscia sicula - Vandel 1946: 202, figs 50-59.

\section{Records}

Algueirão, Pechão; Algarão Menor do Paulino, Loulé, Algarve Province (Vandel 1946).

\section{Distribution}

Portugal, Sicily, Ustica Island, Pantelleria Island and Malta.

\section{Remarks}

According to Schmalfuss (2003), this blind and depigmented species might be a junior synonym of Anaphiloscia simoni Racovitza, 1907, described on the basis of a female specimen from a cave on Mallorca, Balearic Islands (Racovitza 1907; Arcangeli 1934) and later recorded from western Spain, Morocco, Algeria and Libya (Cyrenaica). Vandel (1972) seems to have considered the two species as synonymous, without formally discussing the issue (Schmalfuss 2003). Since no illustrations of the male characters of $A$. simoni exist, it is impossible to clarify this taxonomic problem without a re-examination of the type material. No specimens of this genus have been collected during our investigations.

\section{Ecological notes}

Epigean species. 
Genus Ctenoscia Verhoeff, 1928

Ctenoscia minima (Dollfus, 1892)

Philoscia minima Dollfus, 1892: 187, 3 figs.

Ctenoscia minima - Vandel 1946: 196, figs 42-49.

\section{Material examined}

PORTUGAL: 1 \%, Gruta da Assafora, Sintra, 4 Apr. 2011 (SR).

\section{Previous records}

Algarão da Ribeira de Alte, Paderne; Algarão do Barrocal do Esguicho, Loulé, Algarve Province (Vandel 1946).

\section{Distribution}

Portugal, Spain (including Canary and Balearic Islands), Corsica, Sardinia, northwestern Italy, Sicily and surrounding islands, Malta, Tunisia and Morocco (Rif).

\section{Remarks}

This epigean species was recently discussed and fully illustrated by Taiti \& Rossano (2015), who considered it to be a senior synonym of Ctenoscia dorsalis (Verhoeff, 1928).

\section{Ecological notes}

Epigean species.

Family Platyarthridae Verhoeff, 1949

Genus Trichorhina Budde-Lund, 1908

Trichorhina anophthalma Arcangeli, 1935

Figs $26 \mathrm{~A}-\mathrm{G}, 27 \mathrm{~A}-\mathrm{C}$

Trichorhina anophthalma Arcangeli, 1935b: 23, figs 19-24.

Trichorhina anophthalma - Vandel 1946: 216, figs 62-63. — Schmölzer 1965: 281, fig. 1104; 1971: 28, 89, 146. - Schmalfuss 2003: 315.

\section{Material examined}

PORTUGAL: 1 đ̊, 1 ㅇ, Algar de Santo António, Estremoz-Cano Massif, 30 Dec. 2009 (MZUF); 9 q , 4 웅, 1 juv., same locality, 30 Mar. 2009 (MZUF); 5 ㅅํ, 3 우오, same locality, 22 May 2009 (SR);

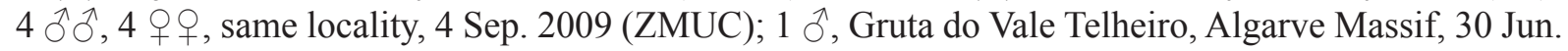
2011 (MZUF); 2 우, Gruta da Senhora, Algarve Massif, 3 Jul. 2011 (SR).

\section{Previous records}

Serpa, Alentejo (Arcangeli 1935b). Palmela, Serra da Arrábida, Setúbal (Vandel 1946).

\section{Distribution}

Known with certainty from southern Portugal and southern Spain (Schmölzer 1971). 


\section{Remarks}

Trichorhina anophthalma is fully illustrated here (Figs 26-27) to facilitate its identification. Hoese (1984) recorded this species from the Canary Islands (Fuerteventura and Tenerife) and considered T. hoestlandti Vandel, 1960 from Madeira (Vandel 1960b) to be a junior synonym of that species. Contrary to this, Schmalfuss (2003) regarded both species as valid. A re-examination of specimens of Trichorhina hoestlandti from Madeira is necessary in order to define the taxonomic status of this species. The specimens of Trichorhina from the Canary Islands recorded by Hoese (1984) also need to be examined for a correct identification.

\section{Ecological notes}

This species is probably endogean and troglophile rather than a true troglobiont.
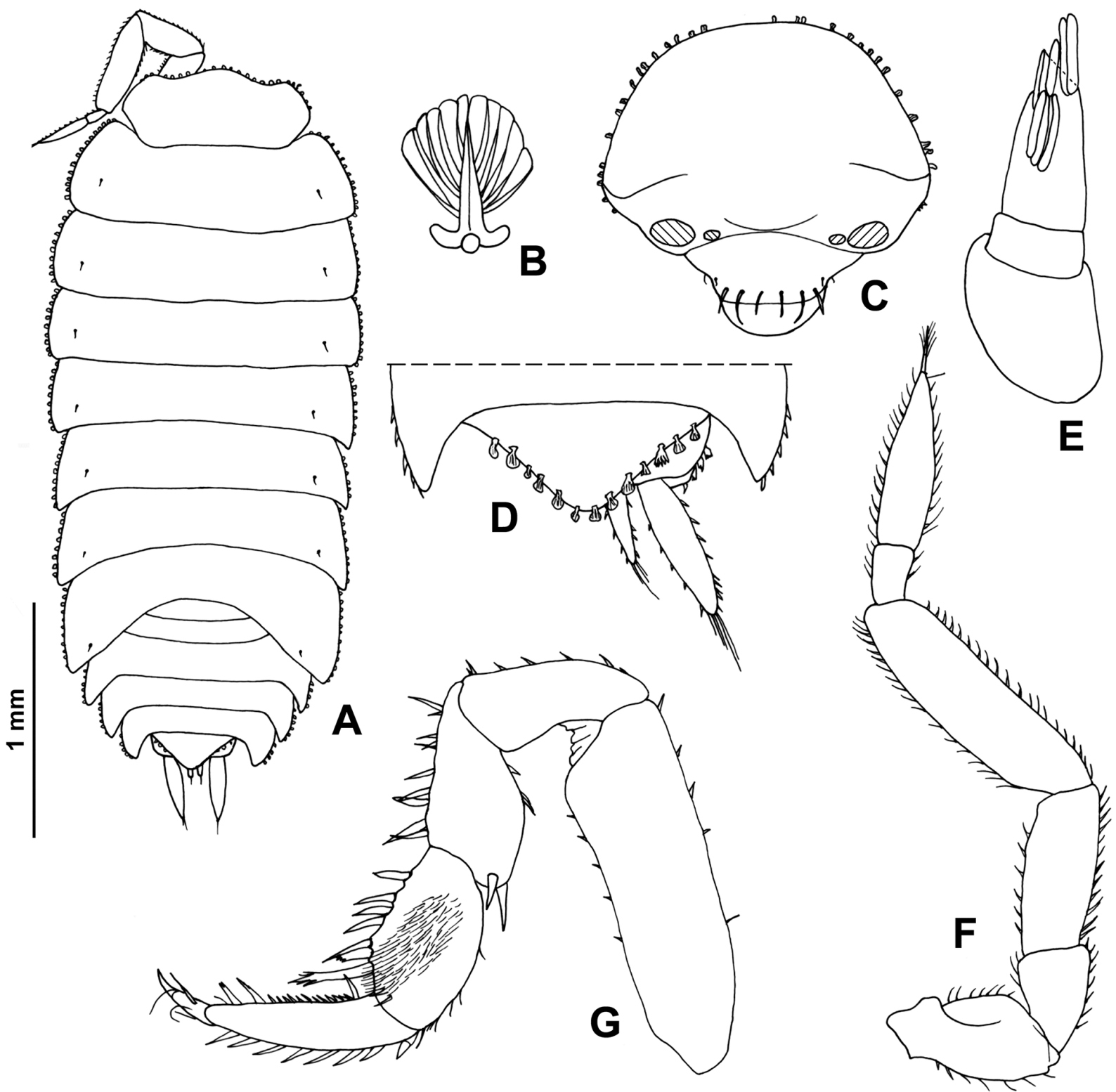

Fig. 26. Trichorhina anophthalma Ancangeli, 1935 from Algar de Santo António, Estremoz-Cano, Ô. A. Adult specimen in dorsal view. B. Scale-seta. C. Cephalon in frontal view. D. Pleonite 5, telson and right uropod. E. Antennula. F. Antenna. G. Pereopod 1. 
Family Porcellionidae Brandt, 1831

Genus Porcellionides Miers, 1877

Porcellionides pruinosus (Brandt, 1833)

Porcellio pruinosus Brandt, 1833: 481.

Metoponorthus (Metoponorthus) pruinosus - Vandel 1946: 272, figs 87-90.

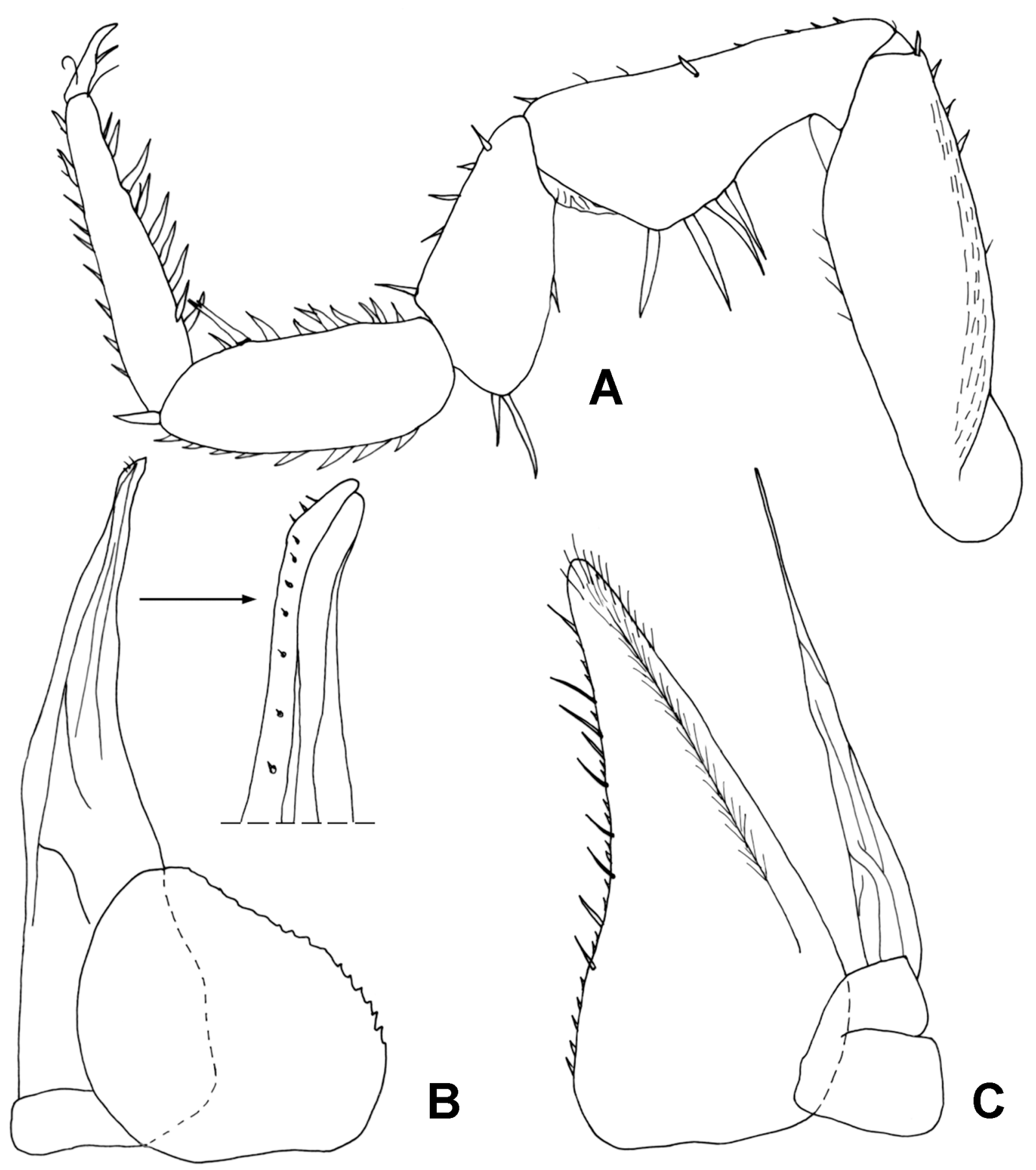

Fig. 27. Trichorhina anophthalma Ancangeli, 1935 from Algar de Santo António, Estremoz-Cano, ô. A. Pereopod 7. B. Pleopod 1. C. Pleopod 2. 


\section{Material examined}

PORTUGAL: 1 q, Algar de Santo António, Estremoz-Cano Massif, 22 May 2009 (SR).

\section{Previous records}

Grutas dos Moinhos da Rocha, Tavira, Faro (Vandel 1946).

\section{Distribution}

Cosmopolitan species of Mediterranean origin.

\section{Ecological notes}

Epigean species, occasionally found at cave entrances.

Porcellionides sexfasciatus (Budde-Lund, 1885)

Metoponorthus sexfasciatus Budde-Lund, 1885: 167.

Metoponorthus (Polytretus) sexfasciatus lusitanus - Vandel 1946: 269, figs 80b-d.

\section{Records}

Gruta do Algar, Mexilhoeirinha, Lagoa; Algarão, Pechão, Algarve Province (Vandel 1946).

\section{Distribution}

Western Mediterranean region, Atlantic coast of Europe and northern Africa, including Atlantic islands. It has also been introduced to many other parts of the world.

\section{Ecological notes}

Epigean species, trogloxene.

Porcellionides cingendus (Kinahan, 1857)

Porcellio cingendus Kinahan, 1857: 279, pl. 19, figs 1-2, 4, 6, 8-9.

Metoponorthus (Lusitanoniscus) cingendus - Vandel 1946: 274, figs 91-97.

\section{Records}

Gruta Baixa do Cabeço dos Mosqueteiros, Aljubarrota; Cova dos Mouros de Vale Ribeiro, Lagoa do Cão, Alcobaça (Vandel 1946).

\section{Distribution}

Southern British Isles, Atlantic coasts of France, Portugal and Spain.

\section{Ecological notes}

Epigean species, trogloxene.

Genus Porcellio Latreille, 1804

Porcellio cavernicolus Vandel, 1946

Figs $28 \mathrm{~A}-\mathrm{G}, 29 \mathrm{~A}-\mathrm{F}$

Porcellio cavernicolus Vandel, 1946: 330, figs 137-143.

Porcellio cavernicolus - Schmölzer 1965: 208, figs 745-746; 1971: 37, 95, 149. - Schmalfuss 2003: 220. — Reboleira et al. 2011a: 27, fig. 3, table 1. 


\section{Material examined}

PORTUGAL: 8 ふふ, 5 우, Gruta d'el Rey, Cantanhede-Outil Massif, 19 May 2009 (MZUF); 4 $\widehat{\partial}$, 5 q $q, 6$ juvs, same locality, 8 Oct. 2009 (SR); 5 $\widehat{\jmath}, 4$ 우, Gruta da Senhora da Estrela, Sicó Massif,

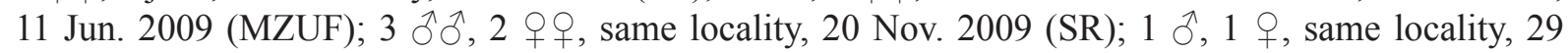

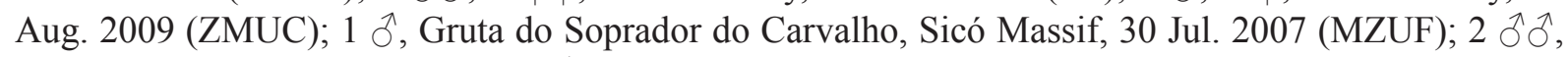
same locality, 17 Jan. 2009 (SR); 1 ô, 2 우, same locality, 30 Jul. 2009 (ZMUC); 1 juv., same locality, 21 Mar. 2009 (SR); many ${ }^{\lambda} \delta$ and + 우, Gruta do Algarinho, Sicó Massif, 21 Mar. 2012 (MZUF); many

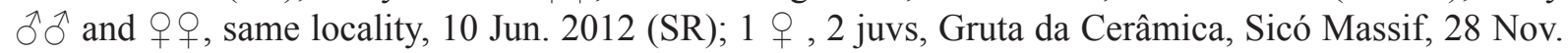
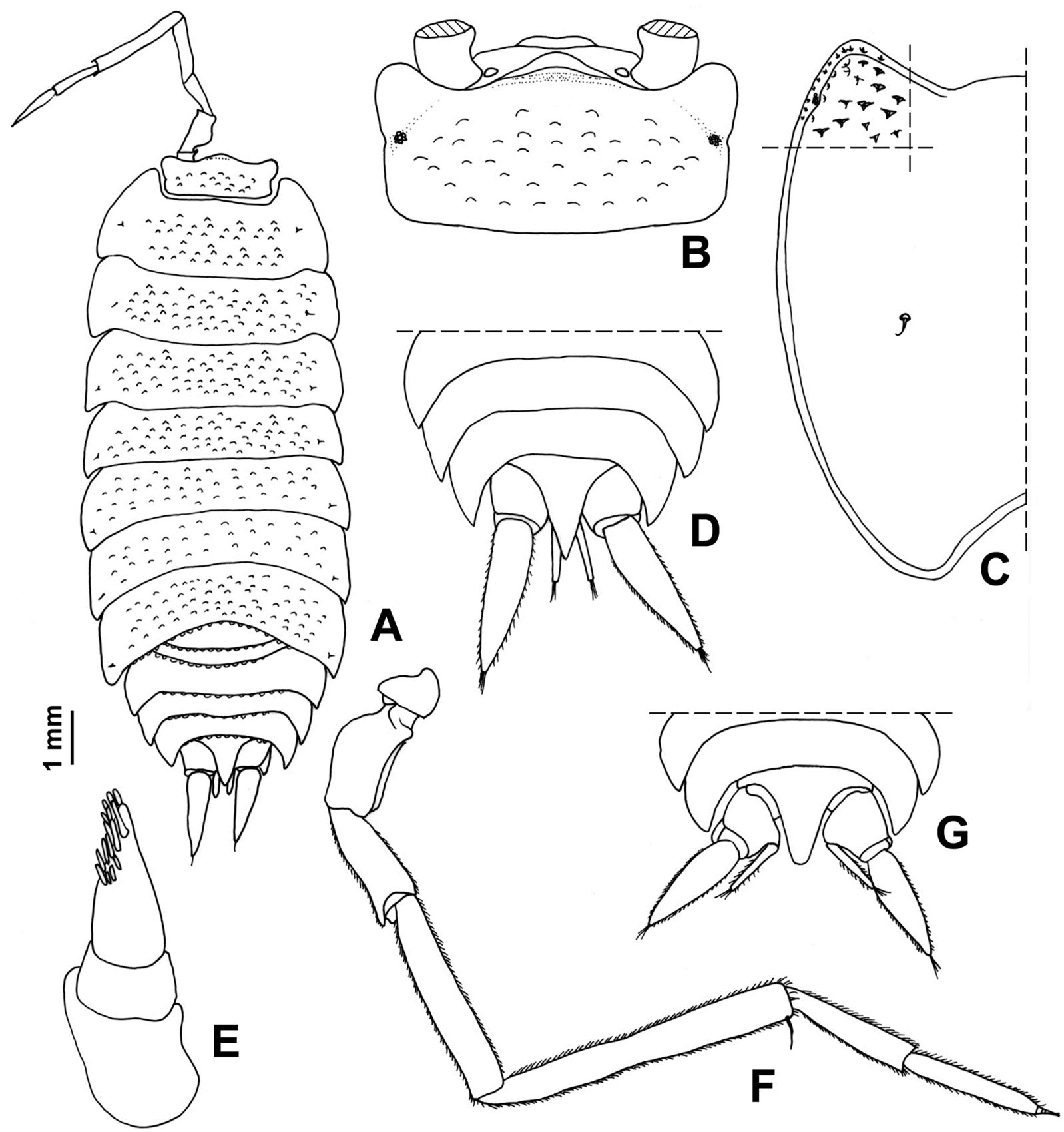

Fig. 28. Porcellio cavernicolus Vandel, 1946. - ô from Gruta da Cerâmica, Sicó. A. Adult specimen in dorsal view. B. Cephalon in dorsal view. C. Epimeron of pereonite 1. D. Pleonites 3-5, telson and uropods. E. Antennula. F. Antenna. — $\widehat{\jmath}$ from Gruta d'el Rey. G. Pleonite 4, 5, telson and uropods. 


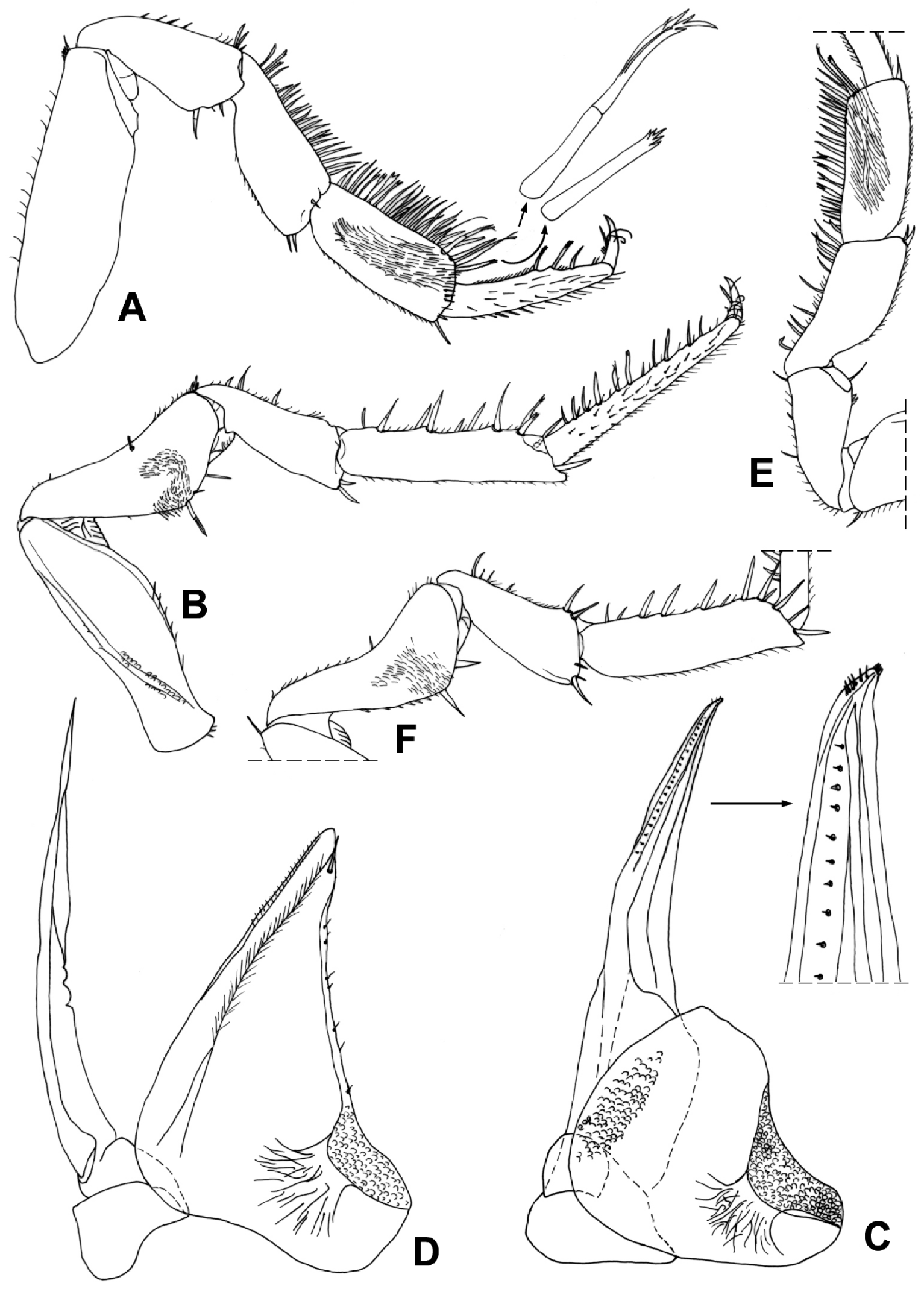

Fig. 29. Porcellio cavernicolus Vandel, 1946. - đ̂̉ from Gruta da Cerâmica, Sicó. A. Pereopod 1. B. Pereopod 7. C. Pleopod 1. D. Pleopod 2. - ô from Gruta d'el Rey, Cantanhede-Outil Massif. E. Pereopod 1. F. Pereopod 7. 


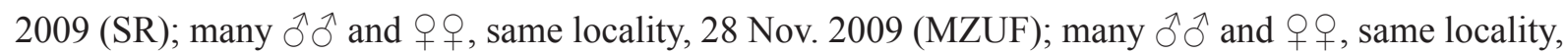

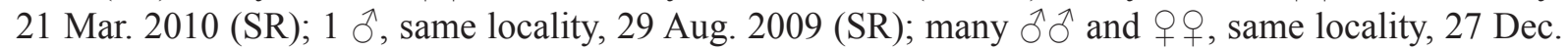
2010 (ZMUC); 1 +, 3 juvs, Gruta Abrigo Tomar I, Sicó Massif, 26 Sep. 2011 (SR).

\section{Previous records}

Algar da Lapa, Ansião; Gruta dos Alqueves, São Martinho do Bispo, Coimbra (Vandel 1946). 3 $え$, 2 우, Gruta Maior da Furjaca, Pampilhosa, Coimbra, 26 Feb. 1987, A. Serra leg. (Cruz 1990).

\section{Distribution}

Species endemic to caves in central Portugal, from Cantanhede-Outil to the southernmost border of the Sicó Massif, but so far absent from the Estremenho karst massif.

\section{Remarks}

This troglobiotic species is fully illustrated here (Figs 28-29) to facilitate its recognition. The finding of this species in Gruta d'el Rey, Cantanhede-Outil Massif, another isolated karst area far from the Sicó localities from where it was described, considerably enlarges the distribution of this species. Populations from the two distinct karst areas show some small differences which, however, do not seem to justify a split of the species. The specimens from Gruta d'el Rey have the apex of the telson more rounded (compare Fig. 28D with 28G), the male pereopod 1 has less numerous setae on the sternal margin of the merus (compare Fig. 29A with 29E), and the male pereopod 7 has a more concave sternal margin of the ischium (compare Fig. 29B with 29F) than specimens from the type locality.

\section{Ecological notes}

This species inhabits the most superficial parts of the caves. It can frequently be found on roots hanging from the ceiling, from which specimens can easily be distinguished by their whitish coloration.

\section{Porcellio dilatatus dilatatus Brandt, 1831}

Porcellio dilatatus Brandt in Brandt \& Ratzeburg, 1831: 78, pl. 12, fig. 6c-d.

Porcellio (Porcellio) dilatatus - Arcangeli 1935b: 12.

Porcellio dilatatus - Vandel 1946: 316, fig. 135.

\section{Material examined}

PORTUGAL: many $\widehat{\partial} \hat{\partial}$ and $\phi$,, Gruta d'el Rey, Cantanhede-Outil Massif, 8 Oct. 2009 (MZUF); many $\widehat{\delta} \hat{o}$ and $q$,, , Gruta dos Moinhos Velhos, Estremenho Massif, 26 Dec. 2006 (ZMUC); 1 ô, 1 o, Gruta dos Bolhos, Cesaredas Plateau, 18 Sep. 2009 (SR); 1 , Gruta de Salir, Caldas da Rainha typhonic

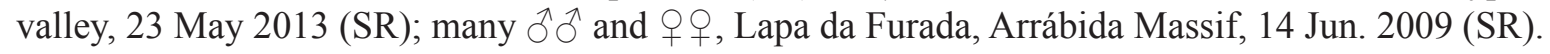

\section{Previous records}

Beja (Arcangeli 1935b). Gruta de Ferreiros, Santo Adrião, Miranda do Douro, Bragança; Ermesinde, Valongo, Porto; Gruta de Sabadal, Portunhos, Cantanhede, Coimbra; Gruta dos Alqueves, S. Martinho do Bispo, Coimbra; Gruta de Legacão, Rabaçal, Penela, Coimbra; Algar N. 1 das Corujeiras, Pombal, Leiria; Algar da Lapa, Ancião, Leiria; $1{ }^{\text {a }}$ Cova da Moura da Ribeira do Sirol, Leiria; Loca dos Vales, Cortes, Leiria; Gruta Alta do Cabeço dos Mosqueiros, Aljubarrota, Leiria; Gruta Baixa do Cabeço dos Mosqueiros, Aljubarrota, Leiria; Algar de João Ramos, Turquel, Leiria; Cova da Moura do Cabeço de Turquel, Alcobaça, Leiria; Algar n ${ }^{\circ} 2$ de Pinheiro, Benedita, Leiria; Casa da Moura, Cesareda, Peniche, Leiria; Gruta do Almonda, Torres Novas, Santarém; Gruta da Senhora da Luz, Rio Maior, Santarém; Gruta das Alcobertas, Rio Maior, Santarém; Algarve da Terra da Rôlha, Cadaval, Lisboa; Gruta N. do Furadoro, Cadaval, Lisboa; Cova da Moura, Cercal, Cadaval, Lisboa; Lapa dos Morcegos, Sesimbra, Setúbal; Lapa do Médico, Portinho da Arrábida, Palmela, Setúbal; Cova da Adiça, Moura, Beja; Gruta 
da Seiceira, Aljezur, Faro; Algarão menor do Paulino, Cerro da Cabeça Gorda, Loulé, Faro; Solestreira Pequena, Querença; Igrejinha de Soidos, Alte, Loulé, Faro; Algueirão dos Mouros, Pechão, Olhão, Faro; Abismo Novo, Moncarapacho, Olhão, Faro; Algarão do Garrafão, Cerro da Cabeça, Olhão, Faro; Ladroeira Pequena, Cerro da Cabeça, Olhão, Faro (Vandel 1946).

\section{Distribution}

Species widely distributed in Europe and introduced to many other parts of the world.

\section{Ecological notes}

This species is a common inhabitant of caves and other subterranean habitats. It has no morphological adaptations to cave life and can be considered as a troglophile.

\section{Porcellio dispar Verhoeff, 1901}

Porcellio dispar Verhoeff, 1901: 407.

Porcellio dispar - Vandel 1946: 289, figs 110-111.

\section{Records}

Algar $n^{\circ} 2$ do Pinheiro, Benedita (Vandel 1946).

\section{Distribution}

Portugal.

\section{Ecological notes}

Epigean species, trogloxene.

Porcellio echinatus Lucas, 1849

Porcellio echinatus Lucas, 1849: 69, pl. 7, fig. 1.

Porcellio echinatus - Vandel 1946: 304, figs 125-130.

\section{Records}

Algar da Serra, Alvaiázere (Vandel 1946).

\section{Distribution}

Southern Portugal, southern Spain, northern Morocco, and north-western Algeria.

\section{Ecological notes}

Epigean species, trogloxene.

Family Armadillidiidae Brandt, 1833

Genus Eluma Budde-Lund, 1885

Eluma caelata (Miers, 1877)

Armadillidium caelatum Miers, 1877: 665, pl. 7, fig. 3.

Eluma purpurascens - Vandel 1946: 357, fig. 158 (not Budde-Lund, 1885).

\section{Records}

Algarve das Gralhas, Cadaval, Montejunto Massif (Vandel 1946). 


\section{Distribution}

Southern British Isles, western France, Portugal, Azores, Madeira, Canary Islands, mainland Spain and north-western Africa. It has been introduced to Tasmania and French Guyana.

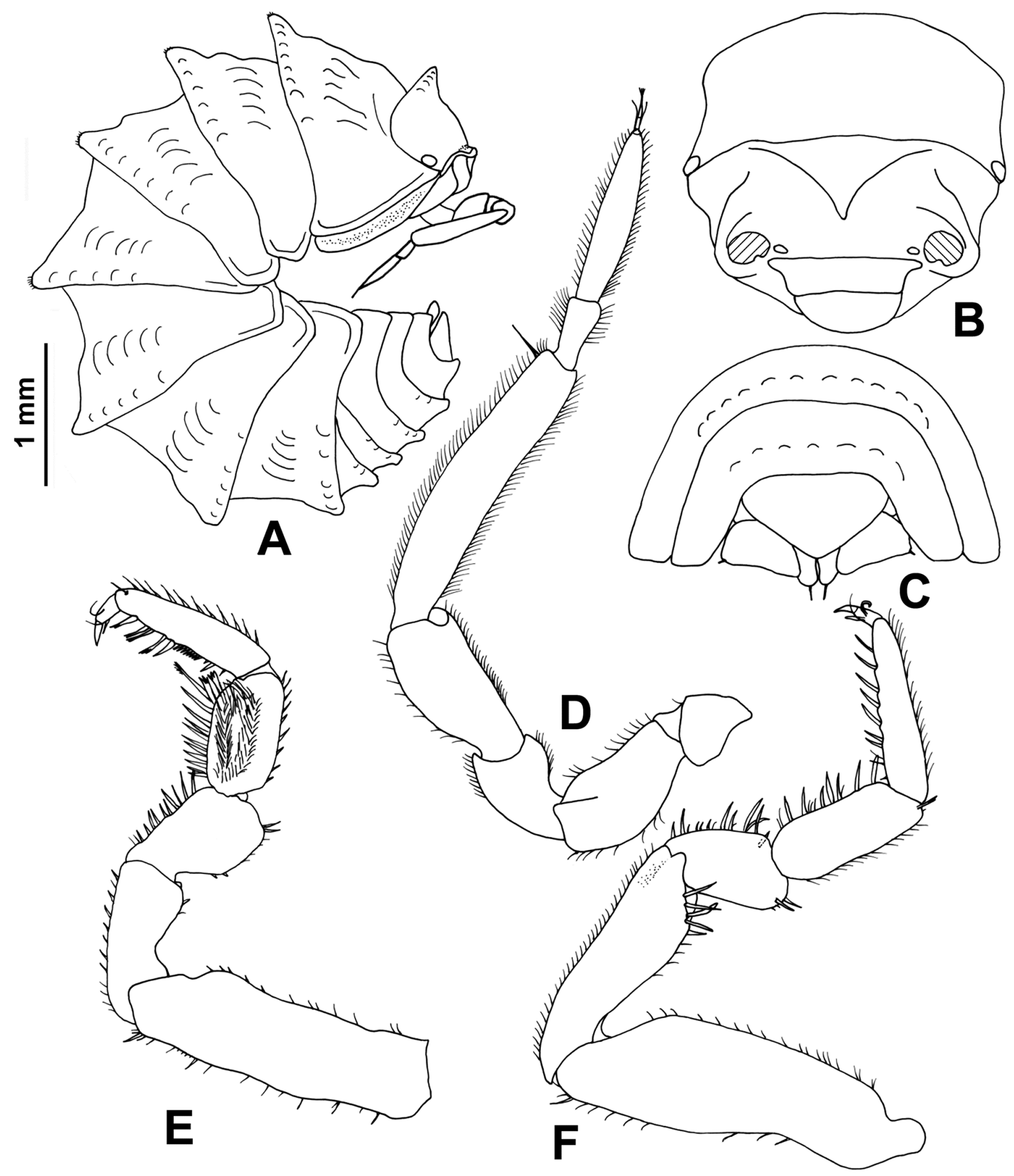

Fig. 30. Eluma tuberculata Cruz, 1991 from Gruta do Soprador do Carvalho, Sicó. — + . A. Specimen in lateral view. B. Cephalon in frontal view. C. Pleonites 4, 5, telson and uropods. - $\widehat{o}$. D. Antenna. E. Pereopod 1. F. Pereopod 7. 


\section{Remarks}

The genus Eluma includes three epigean species: E. caelata, E. tuberculata Cruz, 1991 from Portugal (see below), and E. praticola Taiti \& Rossano, 2015 from the Rif region in Morocco. Eluma caelata has been fully illustrated by Taiti \& Rossano (2015: figs 32-33).

\section{Ecological notes}

Epigean species, trogloxene.

\section{Eluma tuberculata Cruz, 1991}

Figs 30A-F, 31A-B

Eluma tuberculata Cruz, 1991: 73, fig. 1a-f.

Eluma tuberculata - Schmalfuss 2003: 107.

\section{Material examined}

PORTUGAL: many $\widehat{\partial} \hat{o}$ and $q q$, mesovoid shallow substratum (MSS) near Gruta das Alcobertas, Estre-

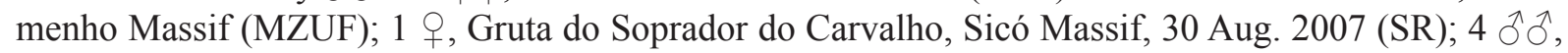

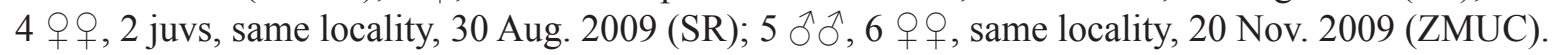

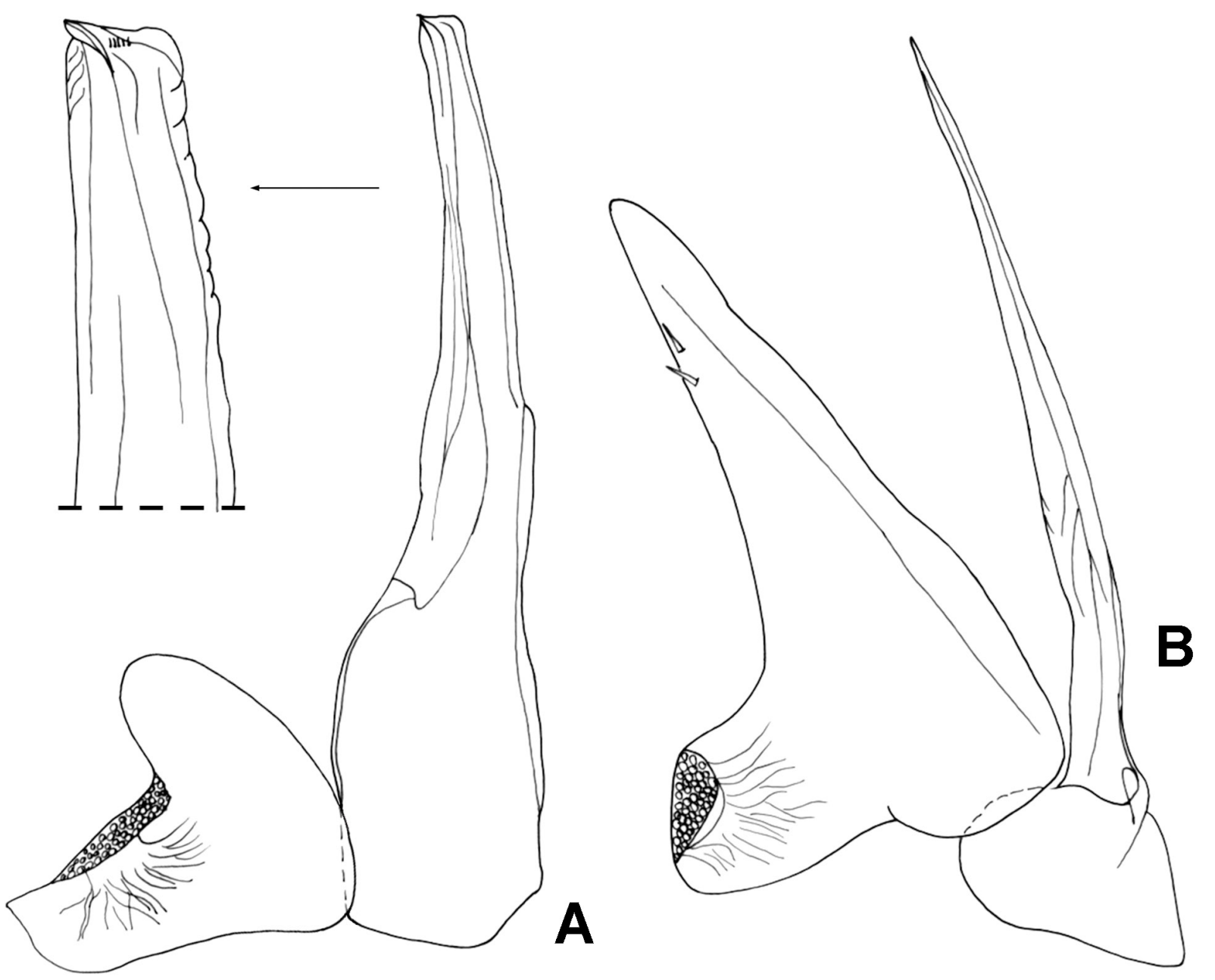

Fig. 31. Eluma tuberculata Cruz, 1991 from Gruta do Soprador do Carvalho, Sicó, đ̃. A. Pleopod 1. B. Pleopod 2. 


\section{Previous records}

São Mamede, Fátima (Cruz 1991).

\section{Distribution}

This species seems to be endemic to central Portugal.

\section{Remarks}

Eluma tuberculata was described by Cruz (1991) based on two females from São Mamede, Fátima. The numerous specimens collected during our research allow us to illustrate the species with its most important features, i.e., the tuberculated body and the schisma on pereonite 1 (Fig. 30A), the cephalon (Fig. 30B), the telson and uropods (Fig. 30C), and the antenna (Fig. 30D). This species has a very plastic morphology concerning the dorsal tubercles, which may be more or less developed. The presence of several adult males permits the description of the male characters which were previously unknown: Pereopods 1 (Fig. 30E) to 6 with brushes of setae on sternal margins of merus and carpus. Pereopod 7 (Fig. 30F) ischium narrow, with straight sternal margin and a ridge on distal part of caudal surface. Pleopod 1 (Fig. 31A) exopod with long, rounded median lobe directed outwards, endopod with distal half having parallel sides and small recurved and pointed apical part not protruding outwards. Pleopod 2 (Fig. 31B) exopod triangular and slightly shorter than endopod.

\section{Ecological notes}

This troglophilic species was collected with traps in the MSS (mesovoid shallow substratum, or 'milieu souterrain superficiel' sensu Juberthie et al. 1980) in the Estremenho Massif as well as in a cave (Gruta Soprador do Carvalho) in Sicó.

Genus Paraschizidium Verhoeff, 1918

\section{Paraschizidium sp.}

Fig. 32A-E

\section{Material examined}

PORTUGAL: 4 우, Algar do Javali, Montejunto Massif, 19 Sep. 2009 (MZUF); 6 우, same locality, 24 Dec. 2009 (SR).

\section{Remarks}

At present, the genus Paraschizidium includes with certainty only three species: P. coeculum (Silvestri, 1897), distributed from Spain to the Balkans, P. hispanum Arcangeli, 1935 from southern Spain, and P. roubali Frankenberger, 1940 from Prague, Czech Republic (Frankenberger 1940), which is probably a junior synonym of $P$. coeculum (see Manicastri \& Taiti 1994). Other species from Greece originally included in the genus Paraschizidium by Schmalfuss (1981) and Sfenthourakis (1992, 1995) were transferred to the genus Schizidium Verhoeff, 1901 by Schmalfuss (2008). Our specimens certainly belong to the genus Paraschizidium: they are depigmented and blind, have no schisma at the posterolateral corner of the pereonite 1 (Fig. 32A), the cephalon has oblique antennal lobes (Fig. 32B-C), the telson is short and triangular (Fig. 32D) and the antennula has two articles (Fig. 32E). Unfortunately, the absence of males in our material does not permit the identification of these specimens to species level.

Genus Trogleluma Vandel, 1946

\section{Remarks}

Trogleluma was erected by Vandel (1946) as a subgenus of Troglarmadillidium Verhoeff, 1900 to include the new species Troglarmadillidium (Trogleluma) machadoi from two caves in South Portugal (see below). At present, the genus Troglarmadillidium only includes the monospecific subgenera 
Troglarmadillidium and Trogleluma, with the species T. (Troglarmadillidium) stygium (Verhoeff, 1900) from Herzegovina, and T. (Trogleluma) machadoi. Both these species have a depigmented body, are blind, have no schisma at the postero-lateral corner of pereonite 1, a triangular telson, and uropods with the exopodite flattened, longer than wide. The two subgenera show quite distinct morphological traits in the cephalic structure: in Troglarmadillidium the triangular frontal scutellum of the cephalon, frontal line and antennal lobes are missing, while in Trogleluma these structures are present. These characters have been confirmed after the examination of a fremale specimen of $T$. (Troglarmadillidium) stygium from Montenegro (Crna Gora, Danilovgrad, Tunjevo, Milojevića vrela, 26 Apr. 1997, leg. and det. I. Karaman). On the basis of these characters we consider Trogleluma as a distinct genus from Troglarmadillidium. Trogleluma includes the type species, Trogleluma machadoi, and a few undescribed new species from Sardinia and Tuscany in Italy (Taiti 2007, unpublished results).

Trogleluma machadoi (Vandel, 1946)

Figs 33A-J, 34A-E

Troglarmadillidium (Trogleluma) machadoi Vandel, 1946: 361, figs 148-157.

Troglarmadillidium (Trogleluma) machadoi - Schmölzer 1965: 307, figs 1232-1233; 1971: 62.

Troglarmadillidium machadoi - Schmölzer 1971: 106, 155. — Schmalfuss 2003: 319. — Reboleira et al. 2011a: 7, table 1 .

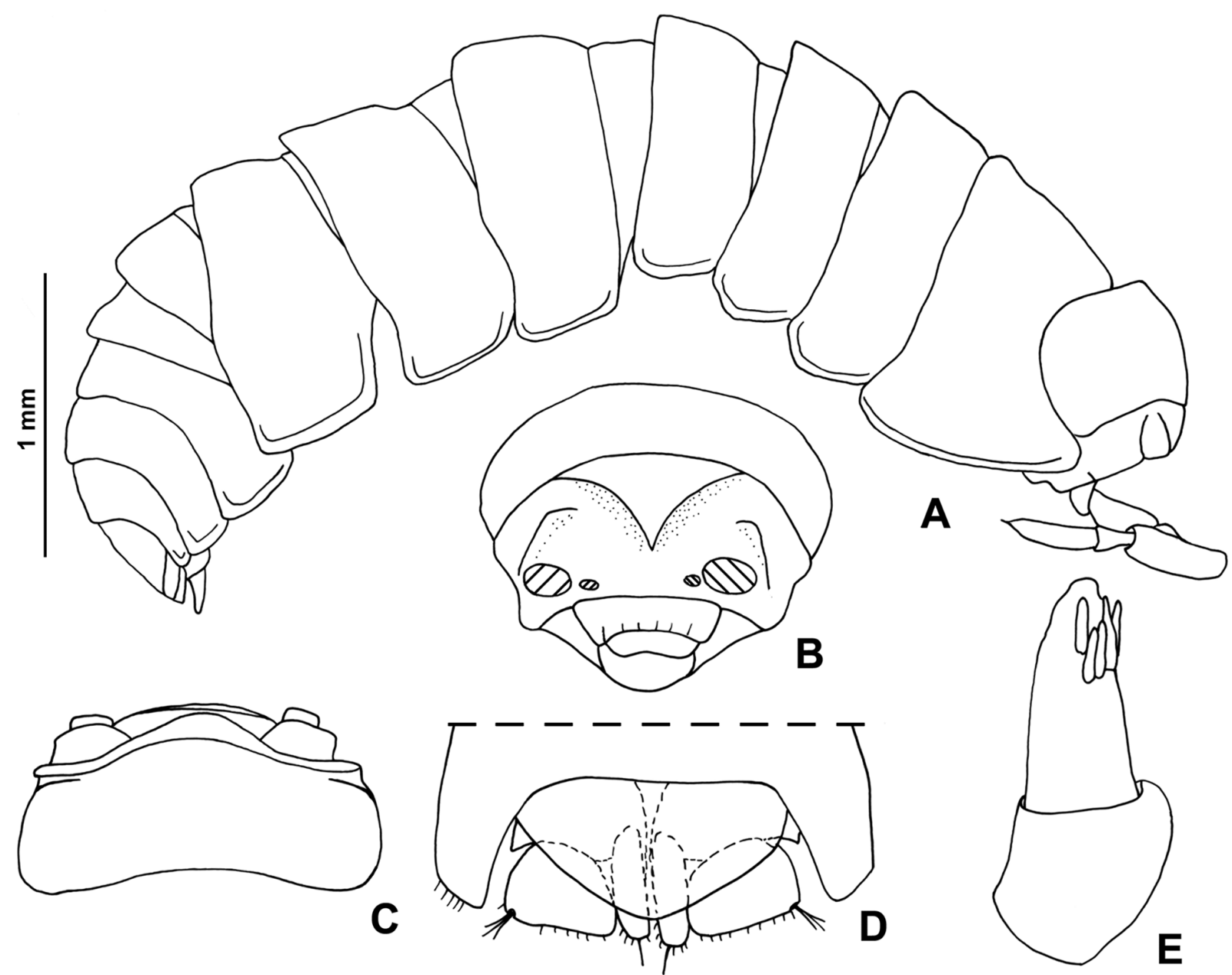

Fig. 32. Paraschizidium sp. from Algar do Javali, Montejunto, ${ }^{+}$. A. Specimen in lateral view. B. Cephalon in frontal view. C. Cephalon in dorsal view. D. Pleonite 5, telson and uropods. E. Antennula. 

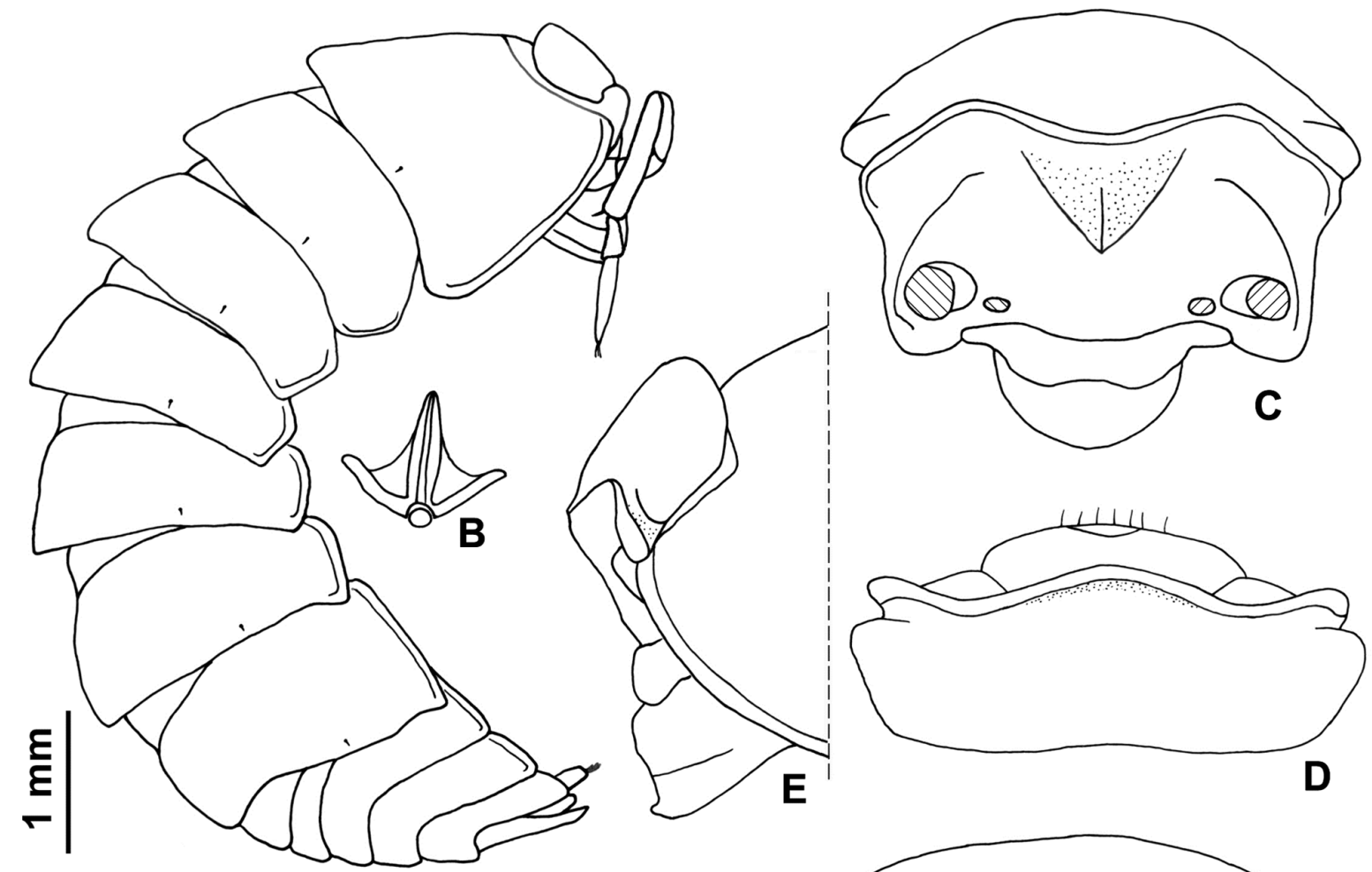

A
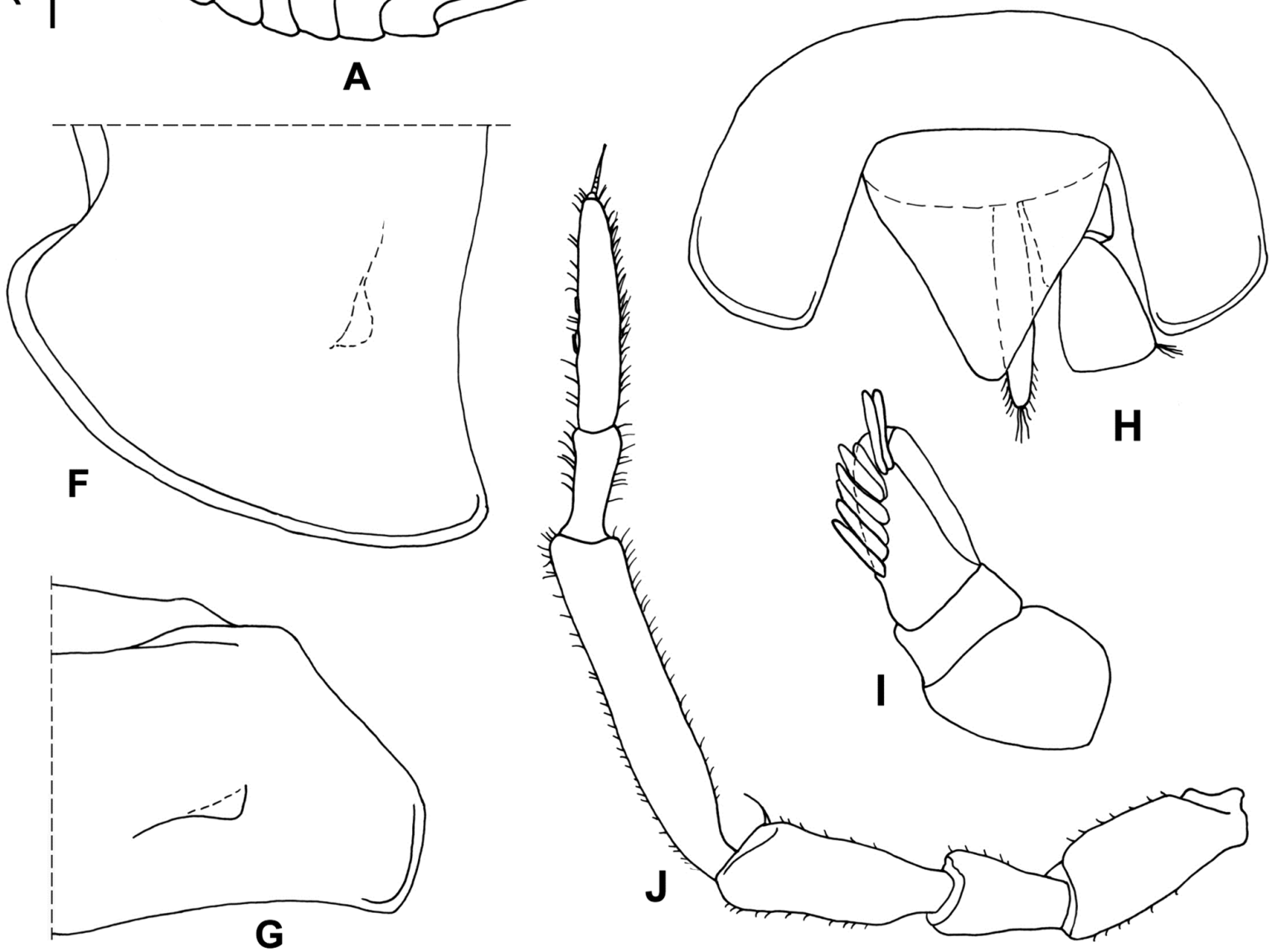

Fig. 33. Trogleluma machadoi (Vandel, 1946) from Algarão do Remexido, Algarve. — $q$. A. Specimen in lateral view. B. Scale-seta. - o . C. Cephalon in frontal view. D. Cephalon in dorsal view. E. Cephalon in lateral view. F. Epimeron of pereonite 1 in dorsal view. G. Epimeron of pereonite 2 in ventral view. H. Pleonite 5, telson and right uropod. I. Antennula. J. Antenna. 


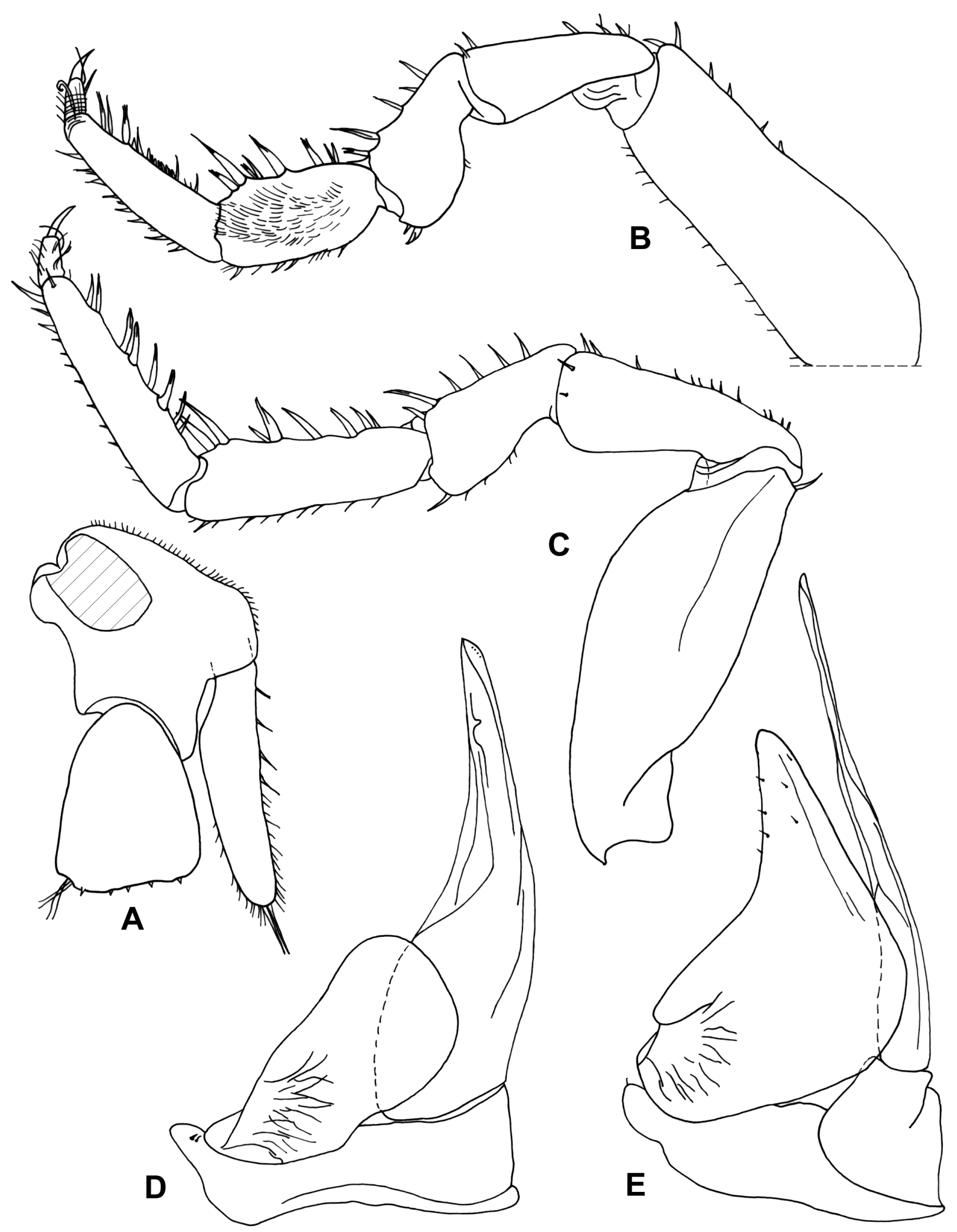

Fig. 34. Trogleluma machadoi (Vandel, 1946) from Algarão do Remexido, Algarve, đ̂. A. Uropod. B. Pereopod 1. C. Pereopod 7. D. Pleopod 1. E. Pleopod 2. 


\section{Material examined}

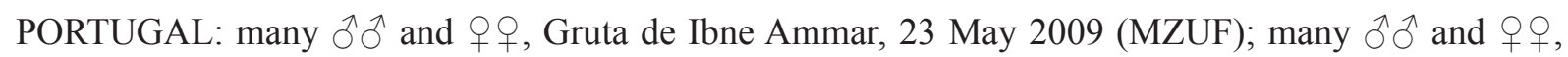

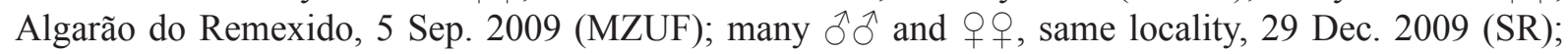

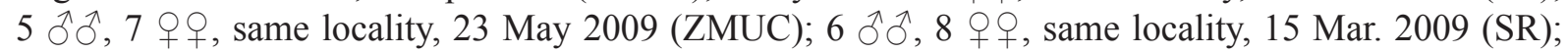

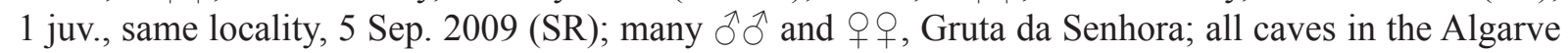
Massif (MZUF).

\section{Previous records}

Algarão Menor do Paulino, Serro da Cabeça Gorda, Loulé, Faro; Abismo Novo, Moncarapacho, Olhão, Faro, Algarve Province (Vandel 1946).

\section{Distribution}

Endemic to caves of the Algarve, the southernmost province of Portugal.

\section{Remarks}

The species is here fully illustrated (Figs 33-34) to facilitate its recognition.

\section{Ecological notes}

Troglobiotic species. The specimens were mostly found inside the clay, which often covers their integument, an observation already pointed out by Vandel (1946). Some individuals were also found walking on cave walls and completely clean of clay. In the caves of the Algarve, this species occurs together with other remarkable troglobiotic species: the pseudoscorpions Titanobochica magna Zaragoza \& Reboleira, 2010 and Lusoblothrus aenigmaticus Zaragoza \& Reboleira, 2012; the spiders Harpactea stalitoides Ribera, 1993 and Teloleptoneta synthetica Machado, 1951; the millipedes Boreviulisoma barrocalense Reboleira \& Enghoff, 2013, Acipes machadoi Enghoff \& Reboleira, 2013, and A. bifillum Enghoff \& Reboleira, 2013; the campodeid Litocampa mendesi Sendra \& Reboleira, 2010; and the giant thysanuran Squamatinia algharbica Mendes \& Reboleira, 2012 (Reboleira et al. 2010c, 2012a, 2012b; Reboleira \& Enghoff 2013; Enghoff \& Reboleira 2013b).

\section{Discussion}

Terrestrial isopods are the most diverse taxonomic group of troglobionts (Reboleira et al. 2013b) in the caves of Portugal, with the number of known species doubled with the present work. The Portuguese oniscidean fauna is now composed of 16 troglobiotic species in mainland Portugal, 5 troglophiles and 6 trogloxenes (Table 2). Two additional species are known from the volcanic caves of the Portuguese Atlantic islands: Trichoniscus bassoti Vandel, 1960 from Madeira (Vandel 1960b; Reboleira et al. 2011a), and a new, still undescribed, trichoniscid from the Azores (Borges et al. 2012). For comparison, 27 species of troglobiotic Oniscidea are known from Spain and 64 from Italy (including Sardinia and Sicily), most of which belonging to the family Trichoniscidae ( 25 and 57 species, respectively).

Trichoniscidae is also the richest family in Portugal, with 14 species frequently found in caves of mainland Portugal, 12 of which are considered to be true troglobionts. Trichoniscoides is the most diverse genus. Trichoniscoides machadoi is an endogean and cavernicolous species occurring in different regions of Portugal, while the remaining species are restricted to single karst areas: T. serrai to the palaeokarst of Vimioso in northeastern Portugal; T. broteroi to the northern part of the Sicó Massif; T. sicoensis to the central area of Sicó; and three species to the Estremenho Massif, the largest karst area of Portugal, i.e., T. meridionalis distributed in caves along its three main central subunits (Serra dos Candeeiros, Santo António Plateau and Serra de Aire/São Mamede Plateau), T. subterraneus in the Aljubarrota Plateau at 
Table 2. Terrestrial isopod species recorded in subterranean habitats of karst areas from Portugal, with ecological classification. $\mathrm{Tb}=$ troglobiont; $\mathrm{Tph}=$ troglophile; $\mathrm{Tx}=$ trogloxene.

\begin{tabular}{|c|c|c|c|}
\hline Family & Species & Ecology & Karst area \\
\hline \multirow[t]{14}{*}{ Trichoniscidae } & Trichoniscoides broteroi & $\mathrm{Tb}$ & Sicó \\
\hline & Trichoniscoides machadoi & Tph & widespread \\
\hline & Trichoniscoides ouremensis & $\mathrm{Tb}$ & Estremenho \\
\hline & Trichoniscoides serrai & $\mathrm{Tb}$ & Vimioso \\
\hline & Trichoniscoides subterraneus & $\mathrm{Tb}$ & Estremenho \\
\hline & Trichoniscoides meridionalis & $\mathrm{Tb}$ & Estremenho \\
\hline & Trichoniscoides bellesi & $\mathrm{Tb}$ & Sicó \\
\hline & Trichoniscoides sicoensis & $\mathrm{Tb}$ & Sicó \\
\hline & Metatrichoniscoides salirensis & $\mathrm{Tb}$ & Caldas da Rainha \\
\hline & Troglonethes olissipoensis & $\mathrm{Tb}$ & Lisbon Peninsula \\
\hline & Troglonethes arrabidaensis & $\mathrm{Tb}$ & Arrábida \\
\hline & Miktoniscus longispina & $\mathrm{Tb}$ & Cesaredas and Sicó \\
\hline & Haplophthalmus siculus & $\mathrm{Tx}$ & Lisbon Peninsula \\
\hline & Moserius inexpectatus & $\mathrm{Tb}$ & Estremenho \\
\hline Styloniscidae & Cordioniscus lusitanicus & $\mathrm{Tb}$ & Alentejo \\
\hline \multirow[t]{2}{*}{ Philosciidae } & Anaphiloscia sicula & Tph & Algarve \\
\hline & Ctenoscia minima & $\mathrm{Tx}$ & Algarve and Lisbon Peninsula \\
\hline Platyarthridae & Trichorhina anophthalma & Tph & Alentejo \\
\hline \multirow[t]{5}{*}{ Porcellionidae } & Porcellionides pruinosus & Tx & widespread \\
\hline & Porcellionides sexfasciatus & $\mathrm{Tx}$ & Algarve \\
\hline & Porcellionides cingendus & $\mathrm{Tx}$ & Estremenho \\
\hline & Porcellio cavernicolus & $\mathrm{Tb}$ & Sicó and Catanhede \\
\hline & Porcellio dilatatus & Tph & widespread \\
\hline \multirow[t]{4}{*}{ Armadillidiidae } & Eluma caelata & Tx & Montejunto \\
\hline & Eluma tuberculata & Tph & Sicó and Estremenho \\
\hline & Paraschizidium sp. & $\mathrm{Tb}$ & Montejunto \\
\hline & Trogleluma machadoi & $\mathrm{Tb}$ & Algarve \\
\hline
\end{tabular}

the western part of the massif, and T. ouremensis in the Fátima Plateau, the eastern part of Estremenho. Despite the sampling effort at their type localities, the troglobiotic species Trichoniscoides broteroi, T. serrai, T. ouremensis and T. subterraneus were not found during our research. The Iberian genus Troglonethes now also includes two species from central Portugal: T. olissipoensis Reboleira \& Taiti sp. nov. from a cave of the Lisbon Peninsula, and T. arrabidaensis Reboleira \& Taiti sp. nov. from a cave in the Arrábida Massif. Miktoniscus longispina Reboleira \& Taiti sp. nov. was collected in two different karst areas: Sicó and the Cesaredas Plateau, the specimens from these localities presenting slight morphological differences from each other.

The styloniscid Cordioniscus lusitanicus Reboleira \& Taiti sp. nov. is described from caves of the Alentejo and Algarve karst areas, more than $200 \mathrm{~km}$ apart in the south of Portugal. 
The family Platyarthridae is represented by the species Trichorhina anophthalma, described from endogean habitats in Palmela, the Arrábida karst massif and Serpa (Baixo Alentejo), but recently also found in karst caves of Alandroal in central Alentejo and in the Algarve.

The family Porcellionidae has one troglobiotic species, Porcellio cavernicolus, described from the Sicó Massif, but now found in caves of the Outil-Cantanhede and Mealhada karst areas, north of the Mondego River, and also inhabiting caves in the Tomar region, significantly increasing its former area of distribution. Slight morphological differences can easily be observed between the extremes of its area of distribution, and molecular studies may clarify the taxonomy of these isolated populations. This species is particularly abundant in shallow caves with roots pending from the ceiling. The troglophilic Porcellio dilatatus dilatatus is very abundant in the most superficial parts of caves from all of Portugal, a feature already pointed out by Vandel (1946).

The family Armadillidiidae is represented by four species belonging to the genera Eluma, Paraschizidium and Trogleluma. The genus Eluma includes the epigean E. caelata and E. tuberculata, originally described from specimens collected under stones in the eastern subunit of the Estremenho Massif (Cruz 1991) and now found in the MSS on the western border of the same massif and also in one cave of Sicó. It appears to be distributed along the MSS, being found inside caves only in their most superficial areas. One cave-adapted species of Paraschizidium was found in a cave of the Montejunto Massif and represents the first record of this genus in Portugal. Trogleluma machadoi is widely distributed in caves along the Barrocal area in the Algarve karst massif.

From a biospeleological point of view, mainland Portugal is traditionally divided into two main areas, the Lusitanian district in central Portugal, and the Baetic district in the south, including the Algarve and extending to Andalucia in Spain (Bellés 1987; Reboleira et al. 2011a). The pattern of troglobiont richness for terrestrial isopods reinforces this separation, with the Lusitanic district clearly rich in troglobiotic species of the genus Trichoniscoides and the Baetic district characterised by the presence of the genera Trogleluma and Cordioniscus.

The recent rise in the number of known subterranean species is a result of the extensive use of a standard sampling methodology in a large number of karst caves, which has also provided new taxa of other caveadapted arthropod groups (Reboleira 2012; Reboleira et al. 2009, 2010a, 2010b, 2010c, 2011b, 2012a, 2012b, 2013b; Reboleira \& Enghoff 2014a). The richness of terrestrial isopods in the subterranean ecosystems of Portugal, and by extension of the Iberian Peninsula, requires a consistent sampling effort to reach a complete level of evaluation.

Terrestrial isopods have been used as bioindicators in land ecosystems, since they are extremely sensitive to contaminants (Paoletti \& Hassall 1999; Paoletti et al. 2007). In the same way, the presence of troglobiotic Oniscidea can be used as indicators of subterranean ecosystem health. A strong argument in support of this is their basal trophic position in cave communities. Decomposing detritus and their strong dependence on water makes them more vulnerable to contamination. The presence of troglobiotic oniscidean species is generally related to deep, stable and undisturbed parts of caves, while in the most disturbed areas only trogloxenes or, at most, troglophile isopods are present, suggesting that they can be used as indicators of the quality of the subterranean ecosystems that they occupy. An example of this is provided by the Gruta dos Moinhos Velhos, with a $300 \mathrm{~m}$ long show cave branch, where only the troglophile Porcellio dilatatus dilatatus is abundant, while the troglobiont Trichoniscoides meridionalis occurs only in the undisturbed galleries, far from human impact. All troglobiotic species of Oniscidea in Portugal lack formal protection (Reboleira et al. 2013a) and their biodiversity patterns should be considered for sustainable management of karst areas in such an important world biodiversity hotspot. 


\section{Acknowledgements}

We express our gratitude to all the Portuguese caving groups: NEUA, GPS, CEAE-LPN, Geonauta, CEEAA, NEL, AES, ECLER, NALGA, Desnível, Alto relevo, DIR-SPE, CIES, SAGA and NEC for their human and material support in the field work and for providing us with speleological information. For the same reasons we are also grateful to F. Regala, R. Francisco, R. Cerqueira, O. Mateus, P. Robalo and S. Medeiros. We are indebted to Parque Natural das Serras de Aire e Candeeiros (PNSAC/ICNF), Grutas de Mira d'Aire, S.A., Câmara Municipal de Penela-CISED, and Câmara Municipal do Alandroal for logistic support during the field work. We thank Dr. Ivo Karaman for kindly sending material of Trogloarmadillidium stygium. The Portuguese Foundation for Science and Technology (FCT, Portugal) provided Ana Sofia Reboleira with a Postdoc grant (SFRH/BPD/92435/2013) and support for a stay of one month at the Istituto per lo Studio degli Ecosistemi, CNR, Florence. All specimens were collected under permits of the Instituto de Conservação da Natureza e das Florestas.

\section{References}

Anderson L.E. 1954. Hoyer's solution as a rapid permanent mounting medium for bryophytes. Bryologist 57: 242-244. http://dx.doi.org/10.2307/3240091

Andreev S. 1986a. Cordioniscus bulgaricus sp. n. (Oniscoidea, Styloniscidae) - premier représentant de la famille Styloniscidae en Bulgarie. Acta zoologica bulgarica 31: 67-70.

Andreev S. 1986b. Contribution à l'étude des isopodes terrestres de la Grèce. 3. Sur trois nouvelles espèces des genres Cordioniscus, Alpioniscus et Trichoniscus et nouvelles données sur les isopodes terr. (Oniscoidea). Biologia gallo-hellenica 11: 153-164.

Andreev S. 2002. Trois nouvelles espèces des genres Cordioniscus et Trichoniscus (Isopoda: Oniscidea) et nouvelles données sur les isopodes terrestres de la Bulgarie. Historia naturalis bulgarica 15: 55-72.

Arcangeli A. 1934. Anaphiloscia sicula, nuova specie di isopodo umicolo della Sicilia. Bollettino del Laboratorio di Zoologia generale e agraria della Reale Scuola superiore d'Agricoltura in Portici 28: $152-158$.

Arcangeli A. 1935a. Gli isopodi terrestri del Portogallo. Bollettino del Laboratorio di Zoologia generale e agraria della Reale Scuola superiore d'Agricoltura in Portici 29: 1-39.

Arcangeli A. 1935b. Isopodi terrestri di caverne della Spagna (Collezione del Museo di Storia naturale di Madrid). Eos 10: 171-195.

Bellés X. 1987. Fauna Cavernícola i Intersticial de la Península Ibèrica i les Illes Balears. Editorial Moll, CSIC-CSIC Press, Palma de Mallorca.

Borges P.A.V., Cardoso P., Amorim I.R., Pereira F., Constância J.P., Nunes J.C., Barcelos P., Costa P., Gabriel R. \& Dapkevicius M.L. 2012. Volcanic caves: priorities for conserving the Azorean endemic troglobiont species. International Journal of Speleology 41 (1): 101-112. http://dx.doi.org/10.5038/1827$\underline{\text { 806X.41.1.11 }}$

Brandt J.F. 1833. Conspectus Monographiae Crustaceorum Oniscodorum Latreillii. Bulletin de la Société impériale des Naturalistes de Moscou 6: 171-193.

Brandt J.F. \& Ratzeburg J.T.C. 1831. Isopoda. In: Brandt J.F. \& Ratzeburg J.T.C. (eds) Medizinische Zoologie oder getreue Darstellung und Beschreibung der Thiere, die in der Arzneimittellehre in Betracht kommen, in systematischer Folge herausgegeben. Vol. 2, parts 1-3: 70-84. Trowitzsch und Sohn, Berlin.

Brian A. 1963. Nota intorno ad alcuni isopodi terrestri raccolti dai signori Ribaldone e Montenegro in grotte della Liguria. Doriana 3: 1-11.

Broly P., Deville P. \& Maillet S. 2013. The origin of terrestrial isopods (Crustacea: Isopoda: Oniscidea). Evolutionary Ecology 27 (3): 461-476. http://dx.doi.org/10.1007/s10682-012-9625-8 
Budde-Lund G. 1885. Crustacea Isopoda Terrestria per Familias et Genera et Species Descripta. Nielsen \& Lydiche, Copenhagen.

Campos-Filho I.S., Araújo P.B., Bichuette M.E., Trajano E. \& Taiti S. 2014. Terrestrial isopods (Crustacea: Isopoda: Oniscidea) from Brazilian caves. Zoological Journal of the Linnean Society 172: 360-425. http://dx.doi.org/10.1111/zoj.12172

Cruz A. 1989. Troglonethes aurouxi gen. n., sp. n. (Oniscidea Trichoniscidae), un isópodo terrestre cavernícola del Levante español. Miscelánea Zoológica 13: 51-54.

Cruz A. 1990. Contribución al Conocimiento de los Isópodos Terrestres (Oniscidea) de la Península Ibérica y Baleares. PhD Thesis, Barcelona University, Spain.

Cruz A. 1991. Especies nuevas o poco conocidas de isópodos terrestres de la Peninsula Ibérica. II. Isópodos epigeos de España y Portugal (Crustacea, Oniscidea). Bulletin de la Société d'Histoire naturelle de Toulouse 127: 71-75.

Cruz A. 1993. Especies nuevas o poco conocidas de isopodos terrestres de la Península Ibérica. III. Trichoniscoides pitarquensis sp. n. y T. serrai sp. n. (Crustacea, Oniscidea, Tichoniscidae). Bulletin de la Société d'Histoire naturelle de Toulouse 127: 15-21.

Dollfus A. 1892. Catalogue raisonné des isopodes terrestres de 1'Espagne. Anales de la Sociedad española de Historia natural 21: 161-190.

Dollfus A. 1896. Crustacés isopodes de la Sicile. Notes faunistiques (Paris) 1896: 1-6.

Enghoff H. \& Reboleira A.S.P.S. 2013a. A new cave-dwelling millipede of the genus Scutogona from central Portugal (Diplopoda, Chordeumatida, Chamaesomatidae). Zootaxa 3736 (2): 175-186. http:// dx.doi.org/10.11646/zootaxa.3736.2.5

Enghoff H. \& Reboleira A.S.P.S. 2013b. Subterranean species of Acipes Attems, 1937 (Diplopoda, Julida, Blaniulidae). Zootaxa 3652 (4): 485-491. http://dx.doi.org/10.11646/zootaxa.3652.4.6

Frankenberger Z. 1940. Paraschizidium roubali sp. n. (Isopoda - Oniscoidea). Věstnik československé zoologické Společnosti v Praze 8: 7-11.

Gregory S.J., Lee P., Read H.J. \& Richards P. 2012. Woodlice (Isopoda: Oniscidea) collected from northwest Spain and northern Portugal in 2004 by the British Myriapod and Isopod Group. Bulletin of the British Myriapod and Isopod Group 26: 6-23.

Hoese B. 1984. Checkliste der terrestrischen Isopoden der Kanarischen Inseln (Crustacea: Isopoda: Oniscoidea). Courier Forschungsinstitut Senckenberg 71: 27-37.

Hornung E. 2011. Evolutionary adaptation of oniscidean isopods to terrestrial life: Structure, physiology and behavior. Terrestrial Arthropod Reviews 4 (2): 95-130.http://dx.doi.org/10.1163/187498311X576262

Juberthie C., Delay B. \& Bouillon M. 1980. Sur l'existence d'un milieu souterrain superficiel en zone non calcaire. Comptes Rendus de l'Académie des Sciences 290: 49-52.

Kinahan J. 1857. Analysis of certain allied genera of terrestrial isopods; with description of a new genus, and a detailed list of the British species of Ligia, Philougria, Philoscia, Porcellio, Oniscus and Armadillium [sic]. Natural History Review 4: 258-282.

Lucas H. 1849. Première Classe. Crustacés. Troisième Famille. Les Cloportides. Exploration scientifique de l'Algerie, pendant les années 1840, 1841, 1842. Sciences physiques, Zoologie 1: 67-73. Available from http://biodiversitylibrary.org/page/46116745 [accessed 1 Dec. 2015]

Manicastri C. \& Taiti S. 1994. Gli isopodi terrestri dell'Appennino umbro-marchigiano (Crustacea, Oniscidea). Biogeographia 17: 125-150. 
Miers E.J. 1877. On a collection of Crustacea, Decapoda and Isopoda, chiefly from South America, with descriptions of new genera and species. Proceedings of the Zoological Society of London 1877: 653-679. Avalialbe from http://biodiversitylibrary.org/page/28518607 [accessed 1 Dec. 2015]

Oliver P. \& Trew A. 1981. A new species of Metatrichoniscoides (Crustacea: Isopoda: Oniscoidea) from the coast of South Wales, U.K. Journal of Natural History 15: 525-529. http://dx.doi. org/10.1080/00222938100770371

Paoletti M.G. \& Hassall M. 1999. Woodlice (Isopoda: Oniscidea): their potential for assessing sustainability and use as bioindicators. Agriculture, Ecosystems \& Environment 74 (1): 157-165. http:// dx.doi.org/10.1016/S0167-8809(99)00035-3

Paoletti M.G., Osler G.H., Kinnear A., Black D.G., Thomson L.J., Tsitsilas A., Sharley D., Judd S., Neville P. \& D'Inca A. 2007. Detritivores as indicators of landscape stress and soil degradation. Animal Production Science 47 (4): 412-423.

Racovitza E. 1907. Biospéologica. IV. Isopodes terrestres (première série). Archives de Zoologie expérimentale et générale, 4 Série 7: 145-225.

Reboleira A.S.P.S. 2007. Os Coleópteros (Insecta, Coleoptera) Cavernícolas do Maciço Calcário Estremenho: uma Aproximação à sua Biodiversidade. MSc Thesis, University of Aveiro, Portugal.

Reboleira A.S.P.S. 2012. Biodiversity and Conservation of Subterranean Fauna of Portuguese Karst. $\mathrm{PhD}$ Thesis, University of Aveiro, Portugal.

Reboleira A.S.P.S. \& Enghoff H. 2013. The genus Boreviulisoma Brolemann, 1928 - an Iberian-N African outlier of a mainly tropical tribe of millipedes (Diplopoda: Polydesmida: Paradoxosomatidae). Zootaxa 3646 (5): 516-528. http://dx.doi.org/10.11646/zootaxa.3646.5.2

Reboleira A.S.P.S. \& Enghoff H. 2014a. Millipedes (Diplopoda) from caves of Portugal. Journal of Cave and Karst Studies 76 (1): 20-25. http://dx.doi.org/10.4311/2013LSC0113

Reboleira A.S.P.S. \& Enghoff H. 2014b. Sireuma, a new genus of subterranean millipedes from the Iberian Peninsula (Diplopoda, Chordeumatida, Opisthocheiridae). Zootaxa 3785 (1): 79-86. http:// dx.doi.org/10.11646/zootaxa.3785.1.6

Reboleira A.S.P.S. \& Ortuño V.M. 2011. Description of the larva and female genitalia of Trechus gamae with data on its ecology. Bulletin of Insectology 64 (1): 43-52.

Reboleira A.S.P.S., Gonçalves F. \& SerranoA. 2009. Two new species of cave dwelling Trechus Clairville, 1806 of the fulvus-group (Coleoptera, Carabidae, Trechinae) from Portugal. Deutsche Entomologische Zeitschrift 56 (1): 101-107. http://dx.doi.org/10.1002/mmnd.200900009

Reboleira A.S.P.S., Ortuño V.M., Gonçalves F. \& Oromí P. 2010a. A hypogean new species of Trechus Clairville, 1806 (Coleoptera, Carabidae) from Portugal and considerations about the T. fulvus species group. Zootaxa 2689: 15-26.

Reboleira A.S.P.S., Sendra A., Gonçalves F. \& Oromí P. 2010b. The first hypogean dipluran from Portugal: description of a new species of the genus Litocampa (Diplura: Campodeidae). Zootaxa 2728: $50-56$.

Reboleira A.S.P.S., Zaragoza J., Gonçalves F. \& Oromí P. 2010c. Titanobochica, surprising discovery of a new cave-dwelling genus from southern Portugal (Arachnida: Pseudoscorpiones: Bochicidae). Zootaxa 2681: 1-19.

Reboleira A.S.P.S., Borges P., Gonçalves F., Serrano A.R.M. \& Oromí P. 2011a. The subterranean fauna of a biodiversity hotspot region - Portugal: an overview and its conservation. International Journal of Speleology 40 (1): 23-37. http://dx.doi.org/10.5038/1827-806X.40.1.4 
Reboleira A.S.P.S., Gonçalves F. \& Oromí P. 2011b. On the Iberian endemic subgenus Lathromene Koch (Coleoptera: Staphylinidae: Paederinae): description of the first hypogean Domene Fauvel, 1872 from Portugal. Zootaxa 2780: 48-56.

Reboleira A.S.P.S., Gonçalves F., Oromí P. \& Mendes L.F. 2012a. Squamatinia algharbica gen. n. sp. n., a remarkable new Coletiniinae silverfish (Zygentoma: Nicoletiidae) from caves in southern Portugal. Zootaxa 3260: 33-46.

Reboleira A.S.P.S., Zaragoza J.A., Gonçalves F. \& Oromí P. 2012b. Lusoblothrus, a new syarinid pseudoscorpion genus (Arachnida) from Portugal, occupying an isolated position within the Holarctic fauna. Zootaxa 3544: 52-62.

Reboleira A.S.P.S., Abrantes N.A., Oromí P. \& Gonçalves F. 2013a. Acute toxicity of copper sulfate and potassium dichromate on stygobiont Proasellus: general aspects of groundwater ecotoxicology and future perspectives. Water, Air \& Soil Pollution 224 (5): 1550-1559. http://dx.doi.org/10.1007/s11270013-1550-0

Reboleira A.S.P.S., Gonçalves F. \& Oromí P. 2013b. Literature survey, bibliographic analysis and a taxonomic catalogue of subterranean fauna from Portugal. Subterranean Biology 10: 51-60. http:// dx.doi.org/10.3897/subtbiol.10.4025

Reboleira A.S.P.S., Zaragoza J.A., Gonçalves F. \& Oromí P. 2013c. On hypogean Roncocreagris (Arachnida: Pseudoscorpiones: Neobisiidae) from Portugal, with descriptions of three new species. Zootaxa 3670 (2): 283-299.

Řezáč M., Pekár S. \& Lubin Y. 2008. How oniscophagous spiders overcome woodlouse armour. Journal of Zoology 275 (1): 64-71. http://dx.doi.org/10.1111/j.1469-7998.2007.00408.x

Schmalfuss H. 1981. Die Isopoden der Nördlichen Sporaden (Ägäis). Stuttgarter Beiträge zur Naturkunde, Serie A 343: 1-24.

Schmalfuss H. 2003. World catalog of terrestrial isopods (Isopoda: Oniscidea). Stuttgarter Beiträge zur Naturkunde, Serie A 654: 1-341.

Schmalfuss H. 2008. The terrestrial isopod genus Schizidium (Isopoda: Oniscidea): systematics, distribution, morphology. Stuttgarter Beiträge zur Naturkunde A (New Series) 1: 143-151.

Schmalfuss H. \& Erhard F. 1998. Die Land-Isopoden (Oniscidea) Griechenlands. 19. Beitrag: Gattung Cordioniscus (Styloniscidae). Stuttgarter Beiträge zur Naturkunde, Serie A 582: 1-20.

Schmölzer K. 1965. Ordnung Isopoda (Landasseln). Bestimmungsbücher zur Bodenfauna Europas, Issues 4 \& 5, Academie Verlag, Berlin.

Schmölzer K. 1971. Die Landisopoden der Iberischen Halbinsel. Monografias de Ciencia moderna 80: $1-161$.

Sfenthourakis S. 1992. New species of terrestrial isopods (Isopoda, Oniscidea) from Greece. Crustaceana 63: 199-209.

Sfenthourakis S. 1995. New species of terrestrial isopods (Oniscidea) from the central Aegean islands. Stuttgarter Beiträge zur Naturkunde, Serie A 519: 1-21.

Strouhal H. 1940. Moserius percoi nov. gen. nov. spec., eine neue Höhlen-Höckerassel, nebst einer Übersicht über die Halplophthalminen. Zoologischer Anzeiger 129: 13-30.

Tabacaru I. 1993. Sur la classification des Trichoniscidae et la position systématique de Thaumatoniscellus orghidani Tabacaru, 1973 (Crustacea, Isopoda, Oniscidea). Travaux de l'Institut de Spéologie "Émile Racovitza" 32: 43-85.

Taiti S. 2007. 10. Gli Isopodi terrestri. In: Scapini F. \& Nardi M. (eds) Il Parco Regionale della Maremma e il suo Territorio: 91-101. Pacini Editore, Pisa. 
Taiti S. \& Ferrara F. 1995. Isopodi terrestri (Crustacea, Oniscidea) delle grotte della Toscana (Italia centrale). Mémoires de Biospéologie 22: 169-196.

Taiti S. \& Rossano C. 2015. Terrestrial isopods from the Oued Laou basin, north-eastern Morocco (Crustacea, Oniscidea), with descriptions of two new genera and seven new species. Journal of Natural History 49 (33-34): 2067-2138. http://dx.doi.org/10.1080/00222933.2015.1009512

Taiti S. \& Xue Z. 2012. The cavernicolous genus Trogloniscus nomen novum, with descriptions of four new species from southern China (Crustacea, Oniscidea, Styloniscidae). Tropical Zoology 25 (4): 183-209. http://dx.doi.org/10.1080/03946975.2012.751240

Vandel A. 1942. Espèces françaises, nouvelles ou peu connues de Trichoniscidae (isopodes terrestres). Bulletin de la Société zoologique de France 67: 133-141.

Vandel A. 1946. Crustacés isopodes terrestres (Oniscoïdea) épigés et cavernicoles du Portugal. Anais da Faculdade de Ciências do Porto 30: 135-427.

Vandel A. 1947. L'énigme de la reproduction des arthropodes cavernicoles et plus particulièrement des isopodes terrestres. Bulletin de la Société d'Histoire naturelle de Toulouse 82: 263-275.

Vandel A. 1948. La faune isopodique française (Oniscoïdes ou Isopodes terrestres). Sa répartition, ses origines et son histoire. Revue française d'Entomologie 15: 101-139.

Vandel A. 1952a. Biospeologica LXXIII. Isopodes terrestres (troisième série). Archives de Zoologie expérimentale et générale 88: 231-362.

Vandel A. 1952b. Les trichoniscides (Crustacés - Isopodes) de l'hémisphère austral. Mémoires du Muséum national d'Histoire naturelle, Série A 6: 1-116.

Vandel A. 1959. La faune isopodique cavernicole de la Grèce continentale (récoltes du Dr. K. Lindberg, Lund). Notes biospéologiques 13: 131-140.

Vandel A. 1960a. Isopodes terrestres (première partie). Faune de France 64: 1-416.

Vandel A. 1960b. Les isopodes terrestres de l'Archipel Madérien. Mémoires du Muséum national d'Histoire naturelle, Série A 22: 1-155.

Vandel A. 1962. Isopodes terrestres (deuxième partie). Faune de France 66: 417-931.

Vandel A. 1968. Description d'un nouveau représentant du genre Cordioniscus (Crustacea, Isopoda, Oniscoidea, Styloniscidae) suivie de considérations sur les voies de migration de certaines lignées d'isopodes terrestres. Annales de Spéléologie 23: 621-632.

Vandel A. 1972. Les isopodes terrestres et cavernicoles de la Catalogne. Miscelánea Zoológica 3: 1-19.

Verhoeff K.W. 1901. Über paläarktische Isopoden (7. Aufsatz). Zoologischer Anzeiger 24: 403-408, 417-421. Available from http://biodiversitylibrary.org/page/9745364 [accessed 1 Dec. 2015]

Manuscript received: 26 September 2015

Manuscript accepted: 3 November 2015

Published on: 11 December 2015

Topic editor: Rudy Jocqué

Desk editor: Danny Eibye-Jacobsen

Printed versions of all papers are also deposited in the libraries of the institutes that are members of the EJT consortium: Muséum national d'Histoire naturelle, Paris, France; Botanic Garden Meise, Belgium; Royal Museum for Central Africa, Tervuren, Belgium; Natural History Museum, London, United Kingdom; Royal Belgian Institute of Natural Sciences, Brussels, Belgium; Natural History Museum of Denmark, Copenhagen, Denmark. 